\title{
30. CHEMICAL AND ISOTOPIC CONSTRAINTS ON THE ORIGIN OF BASALTS FROM NINETYEAST RIDGE, INDIAN OCEAN: RESULTS FROM DSDP LEGS 22 AND 26 AND ODP LEG $121^{1}$
}

\author{
A. D. Saunders, ${ }^{2}$ M. Storey, ${ }^{2}$ I. L. Gibson, ${ }^{3}$ P. Leat, ${ }^{4,5}$ J. Hergt, ${ }^{6}$ and R. N. Thompson ${ }^{4}$
}

\begin{abstract}
On Leg 121 of the Ocean Drilling Program, we recovered basaltic rocks from a total of three basement sites in the southern, central, and northern regions of Ninetyeast Ridge. These new sites complement the previous four basement holes drilled during Legs 22 and 26 of the Deep Sea Drilling Project, and confirm the predominantly tholeiitic, light rare earth element-enriched character of the basalts that cap the ridge. The basalts show marked iron enrichment; ferrobasalts occur at Sites 214 and 216 and oceanic andesites at Site 253. All of the basalts recovered during Leg 121 are altered, and range from aphyric olivine tholeiites (Site 756), to strongly plagioclase-phyric basalts (Site 757). Basalts from Site 758, which were clearly erupted in a submarine environment (pillow basalts are present in the section), are sparsely to strongly plagioclase-phyric. The basalts recovered at any one hole are isotopically homogeneous (except for the basalts from Site 758, which show a range of $\mathrm{Pb}$ isotopes), and it is possible to relate the magmas at any one site by high-level fractionation processes. However, there are significant variations in isotope ratios and highly incompatible element ratios between sites, which suggest that the mantle source for the ridge basalts was compositionally variable. Such variation, in view of the large volume of magmatic products that form the ridge system, is not surprising. There is not, however, a systematic variation in basalt composition along the ridge.

We agree with previous models that relate Ninetyeast Ridge to a mantle plume in the southern Indian Ocean. The tholeiitic, iron-enriched, and voluminous character of the ridge basalts is typical of oceanic islands associated with plumes on or near a mid-ocean ridge (e.g., Iceland, Galapagos Islands, and St. Paul/Amsterdam islands). The absence of recovered alkalic suites is inconsistent with an intraplate setting, such as the Hawaiian Islands or Kerguelen Island. Thus, the major element data, like the gravity data, strongly suggest that the ridge was erupted on or very close to an active spreading center. Isotopically, the most likely plume that created the excess magmatism on the Ridge is the Kerguelen-Heard plume system, but the Ninetyeast Ridge basalts do not represent a simple mixing of the Kerguelen plume and mid-ocean Ninetyeast Ridge basalt mantle.
\end{abstract}

\section{INTRODUCTION}

Ninetyeast Ridge, a major aseismic ridge located in the central Indian Ocean, can be traced for about $5000 \mathrm{~km}$ from latitude $30^{\circ} \mathrm{S}$ northward into the Bay of Bengal, where it is buried beneath the Bengal Fan (Fig. 1). With the completion of Ocean Drilling Program (ODP) Leg 121, drilling has recovered basement lithologies at seven sites along the ridge (Table 1). Paleontological and paleomagnetic data indicate that basement ages become younger in a southward direction, from approximately 80 m.y. at the most northerly Site 758 to 38 m.y. at Site 254 near the southern end of the ridge. The available data are broadly consistent with a model whereby the ridge was formed by magmatic activity above a stationary mantle plume or hotspot located at more southerly latitudes. Two groups of modern-day volcanic islands have been identified as recent expressions of this ridge-building plume activity: St. Paul/Amsterdam islands, presently located on the Southeast Indian Ridge at $38^{\circ} \mathrm{S}, 78^{\circ} \mathrm{E}$, and the Kerguelen/Heard islands located in the southern Indian Ocean at about $52^{\circ} \mathrm{S}, 70^{\circ} \mathrm{E}$.

The purpose of this paper is to present new major element, trace element, and isotopic data for basalts from all of the drill sites along Ninetyeast Ridge. Although petrological and geo-

\footnotetext{
'Weissel, J., Peirce, J., Taylor, E., Alt, J., et al., 1991. Proc. ODP, Sci. Results, 121: College Station, TX (Ocean Drilling Program).

${ }^{2}$ Department of Geology, University of Leicester, Leicester LE1 7RH, United Kingdom.

${ }_{3}^{3}$ Department of Geology, University of Waterloo, Ontario, Canada.

${ }^{4}$ Department of Geological Sciences, Science Laboratories, University of Durham, United Kingdom.

5 Current address: British Antarctic Survey, Madingley Rise, Cambridge CB3 OET, United Kingdom.

${ }^{6}$ Department of Earth Sciences, Open University, Walton Hall, Milton Keynes MK7 6AA, United Kingdom.
}

chemical data are available for the earlier Deep Sea Drilling Project (DSDP) sites, it has been necessary to reanalyze the DSDP material to ensure that the data sets are comparable. We find that our data and the published data are similar, although there are some important discrepancies. Furthermore, there are several omissions from the early data sets for DSDP Sites $214,216,253$, and 254; most notably high-precision $\mathrm{Th}, \mathrm{Ta}$, and $\mathrm{Nb}$ data.

Initially, we consider intrasite variability and the role of highlevel fractionation and alteration in controlling basalt compositions. Secondly, we look at intersite and particularly along-ridge variability in order to assess the importance of any temporal changes in magma compositions. Finally, we address the following questions: (1) did any of the present-day plumes in the southern Indian Ocean form Ninetyeast Ridge, (2) does Ninetyeast Ridge represent a trace caused by the interaction of a mantle plume with a spreading axis and possible transform offset, or does it represent the trace of an intraplate hotspot like Hawaii, and (3) does Ninetyeast Ridge record the evolution of a long-lived mantle plume? Ultimately, and beyond the scope of this paper, we ask to what extent can the information from Ninetyeast Ridge help us decipher the nature of mantle chemodynamics in this region; in particular, what is the location and extent of the Dupal (Hart, 1984) mantle source from which Ninetyeast Ridge appears to be derived?

\section{PHYSICAL CHARACTERISTICS AND TECTONIC SETTING OF NINETYEAST RIDGE}

A number of models have been proposed for the origin of Ninetyeast Ridge, none of which completely satisfies the available observational data. It has been suggested that the ridge represents a horst structure (Francis and Raitt, 1967), an overthrust plate boundary (Le Pichon and Heirtzler, 1968), the interaction between a spreading center and transform fault (leaky 


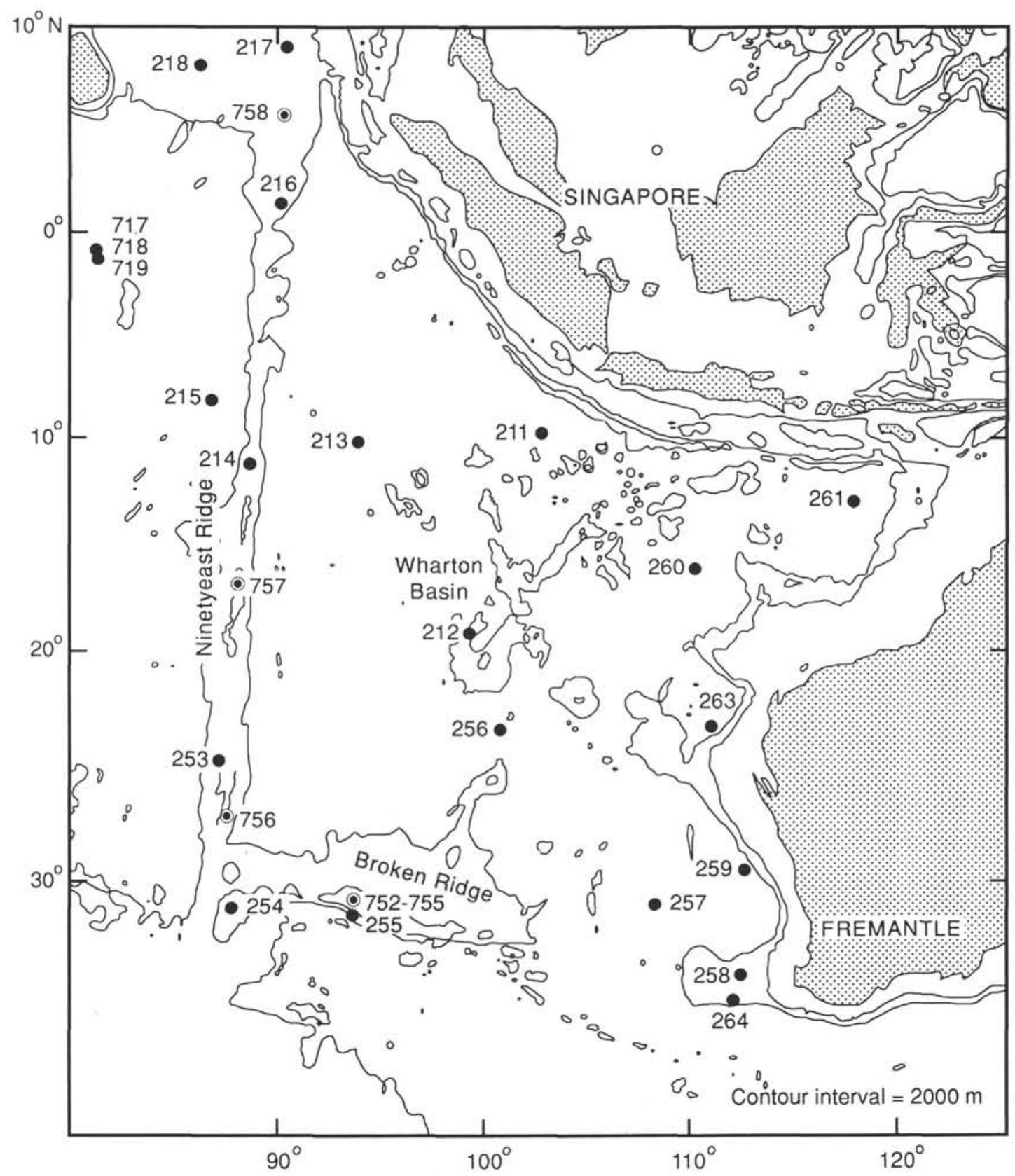

Figure 1. Location map of the Indian Ocean showing DSDP and ODP sites.

transform model) (Sclater and Fisher, 1974), a hotspot trace (Morgan, 1972; Thompson et al., 1974; Frey et al., 1977; Peirce, 1978; Duncan, 1978), a collage of spreading center-transform fault interactions (Sclater et al., 1974; Luyendyk and Davies, 1974), or a collage of hotspot traces (Luyendyk and Rennick, 1977). The problem in evaluating these different models is the paucity of geophysical data for much of Ninetyeast Ridge. Before evaluating these models it is necessary to summarize the available data.

\section{Morphology}

Ninetyeast Ridge is about $5000 \mathrm{~km}$ long and between 50 and $100 \mathrm{~km}$ wide, with a relief above the surrounding ocean floor of about $2 \mathrm{~km}$ (Fig. 1). A wide prominence, Osborne Knoll, lies at about $15^{\circ} \mathrm{S}$. Bathymetric profiles across the southern part of the ridge (south of about $7^{\circ} \mathrm{S}$ ) indicate an asymmetric structure, with a steep eastern scarp slope and a fracture zone, the Ninetyeast Fault, at the foot of the escarpment (Bowin, 1973). North of $7^{\circ} \mathrm{S}$, the bathymetry is more complicated and it appears that the ridge is displaced in an en-echelon fashion by a series of north-northeast-trending faults. The age of this displacement is not known. The total volume of magmatic products of Ninetyeast Ridge is estimated to be about $24 \times 10^{6} \mathrm{~km}^{3}$ (Schubert and Sandwell, 1989), which corresponds to an average magmatic output rate of about $1.5 \mathrm{~km}^{3} \mathrm{yr}^{-1}$ for $40 \mathrm{~m} . \mathrm{y}$.

\section{Eruptive Setting}

All of the DSDP sites on the ridge indicate that the basal sediments were deposited in shallow water except in the case of Site 214, where the basal sediments are subaerial. The ODP sites are more equivocal, but it appears that Sites 756 and 757 were shallow water, whereas Site 758 was deep water. The vesicular 
Table 1. Summary of basement holes at Ninetyeast Ridge, ODP Leg 121 and DSDP Legs 22 and 26.

\begin{tabular}{|c|c|c|c|c|c|c|c|c|}
\hline Site & Hole & Latitude & Longitude & $\begin{array}{l}\text { Water } \\
\text { depth } \\
(\mathrm{m})\end{array}$ & $\begin{array}{l}\text { Oldest } \\
\text { sediment } \\
\text { cored }\end{array}$ & $\begin{array}{l}\text { Basement } \\
\text { penetration } \\
(\mathrm{m})\end{array}$ & $\begin{array}{l}\text { Basement } \\
\text { recovery } \\
(\mathrm{m})\end{array}$ & Comments \\
\hline 254 & 245 & $30^{\circ} 58.15^{\prime} \mathrm{S}$ & $87^{\circ} 53.72^{\prime} \mathrm{E}$ & 1253 & late Eocene-Oligocene & 42.5 & 6.8 & Three units of basalt distinguished. Subaerial eruption likely. \\
\hline \multirow[t]{2}{*}{756} & $756 \mathrm{C}$ & $27^{\circ} 21.253^{\prime} \mathrm{S}$ & $87^{\circ} 35.890^{\prime} \mathrm{E}$ & 1527 & upper Eocene & 8.7 & 5.99 & Two flow units were recognized in Hole $756 \mathrm{C}, 14$ flow units \\
\hline & $756 \mathrm{D}$ & $27^{\circ} 21.288^{\prime} \mathrm{S}$ & $87^{\circ} 35.843^{\prime} \mathrm{E}$ & 1524 & upper Eocene & 82.0 & 26.92 & $\begin{array}{l}\text { in Hole } 756 \mathrm{D} \text {. Basalts are aphyric or sparsely plagioclase- } \\
\text { phyric; frequently vesicular. }\end{array}$ \\
\hline 253 & 253 & $24^{\circ} 52.65^{\prime} \mathrm{S}$ & $87^{\circ} 21.97^{\prime} \mathrm{E}$ & 1962 & mid-Eocene & 1.0 & 0.35 & $\begin{array}{l}\text { Thin, scoriaceous basalt flow in overlying sediments; basal } \\
\text { unit is strongly olivine-phyric. }\end{array}$ \\
\hline \multirow[t]{2}{*}{757} & $757 \mathrm{~B}$ & $17^{\circ} 1.458^{\prime} \mathrm{S}$ & $88^{\circ} 10.899^{\prime} \mathrm{E}$ & 1663 & upper Paleocene & 5.0 & 1.97 & A total of 20 flow units described from both Holes $757 \mathrm{~B}$ and \\
\hline & $757 \mathrm{C}$ & $17^{\circ} 1.389^{\prime} \mathrm{S}$ & $88^{\circ} 1.812^{\prime} \mathrm{E}$ & 1655 & upper Paleocene & 48.3 & 24.95 & $\begin{array}{l}\text { 757C; interbedded tephra common. Basalts are all } \\
\text { plagioclase-phyric, and vesicular. }\end{array}$ \\
\hline 214 & 214 & $11^{\circ} 20.21^{\prime} \mathrm{S}$ & $88^{\circ} 43.08^{\prime} \mathrm{E}$ & 1655 & Paleocene & 10.0 & 4 & $\begin{array}{l}\text { Vesicular and amygdalar basalts. Fine-grained differentiated } \\
\text { andesites emplaced as sills or flows ca. } 22 \mathrm{~m} \text { above } \\
\text { basement. Lignite in basal sediments suggests lagoonal } \\
\text { environment. }\end{array}$ \\
\hline 216 & 216 & $1^{\circ} 27.73^{\prime} \mathrm{N}$ & $90^{\circ} 12.48^{\prime} \mathrm{E}$ & 2237 & late Maestrichtian & 24.5 & 16.7 & Basaltic scoria, and amygdalar basalts with oxidized surfaces. \\
\hline 758 & $758 \mathrm{~A}$ & $5^{\circ} 23.049^{\prime} \mathrm{N}$ & $90^{\circ} 21.673^{\prime} \mathrm{E}$ & 2935 & Campanian & 177.9 & 123.84 & $\begin{array}{l}\text { Massive basalts with minor tephra and hyaloclastite interbeds } \\
\text { near top of hole; pillowed basalts occur in lower part of } \\
\text { hole. }\end{array}$ \\
\hline
\end{tabular}

nature of the basaltic rocks at the majority of the DSDP and ODP sites and the abundance of basaltic tephra are consistent with eruption of basalt near to or above sea level. However, it is equally plausible that the magmas might be volatile-rich.

\section{Age}

There is a general northward increase in the basement depth of the ridge, in broad agreement with the ocean lithosphere subsidence curve, indicating a northward aging of the crust (Fig. 2). Northward aging is also suggested by paleontological studies of recovered drilled material (Table 1), which show that the basal sediments become progressively older northward along the ridge. The oldest sediment age is about 80 m.y. (Campanian) at Site 758 . The ridge continues northward beneath the Bengal Fan, and its thermal signature may be expressed in the mid-Cretaceous Rajmahal Traps in northeast India (Mahoney et al., 1983). The youngest available age is $38 \mathrm{~m} . y$. at Site 254 . It is likely that activity on Ninetyeast Ridge ceased shortly after this when spreading along the Southeast Indian Ridge separated Ninetyeast Ridge from its heat/magma source (Mutter and Cande, 1983). Limited data suggest that along much of its length Ninetyeast Ridge is contemporaneous with the adjacent Indian Plate to the west. The crust in the Wharton Basin to the east ages southward and is separated from Ninetyeast Ridge by the Ninetyeast Fault. There is a broad linear relationship between age and distance along Ninetyeast Ridge, although Site 756 gives an anomalously young estimated basement age (Fig. 2).

\section{Gravity Data}

Bowin (1973) showed that Ninetyeast Ridge has a small freeair gravity anomaly, indicating that the ridge is isostatically compensated at depth. This observation is consistent with the marine magnetic data which indicate that the ridge and the underlying lithosphere are approximately contemporaneous. The horst-andgraben model of Francis and Raitt (1967) and the overthrust plate boundary model of Le Pichon and Heirtzler (1968) may be discounted on the basis of the gravity data.

\section{Paleomagnetic and Paleontological Data}

Prior to Leg 121, paleomagnetic inclination data for basalts from DSDP sites were consistent with cooling of the basalts at approximately $50^{\circ} \mathrm{S}$, albeit with a large degree of uncertainty (Peirce, 1978). The basalt ash sequence of Site 757 and the upper flow sequence from Site 758 also indicate paleolatitudes of about $50^{\circ} \mathrm{S}$, which supports a Kerguelen hotspot origin for this part of Ninetyeast Ridge (Klootwijk et al., this volume). However, the basement sequence of Site 756 indicates a lower paleolatitude of about $43^{\circ} \mathrm{S}$, and there is evidence of a reversed-polarity overprint with a paleolatitude of about $40^{\circ} \mathrm{S}$ in the basalts from Site 758 , which may be related to the St. Paul/Amsterdam hotspot. Corroborative evidence for the formation of Ninetyeast Ridge at high latitudes comes from paleontological studies, which show an increase in the proportion of cold-water (i.e., higher latitude) species in the older sediments at each site.

\section{Geochemical Data}

Basement samples from DSDP Sites 214, 216, 253, and 254 and ODP Sites 756,757 , and 758 are ubiquitously light rare earth element (REE)-enriched tholeiites (with the exception of magnesian basalts encountered at the bottom of Hole 253). Thompson et al. (1974), Frey et al. (1977), and the Leg 121 Shipboard Scientific Party (1989) have suggested that the chemistry of the DSDP basalts is consistent with derivation from a mantle plume, perhaps that presently lying beneath the St. Paul/Amsterdam islands or Kerguelen/Heard islands. Lack of $\mathrm{Pb}$-isotope data has hampered previous interpretations, although Dupré and Allègre (1983) published two sets of $\mathrm{Pb}$ isotope data and used these to suggest that Ninetyeast Ridge originated from the Kerguelen Plume.

Peirce (1978) highlights an important problem with the Kerguelen plume model: first, there is a mismatch between the pre-

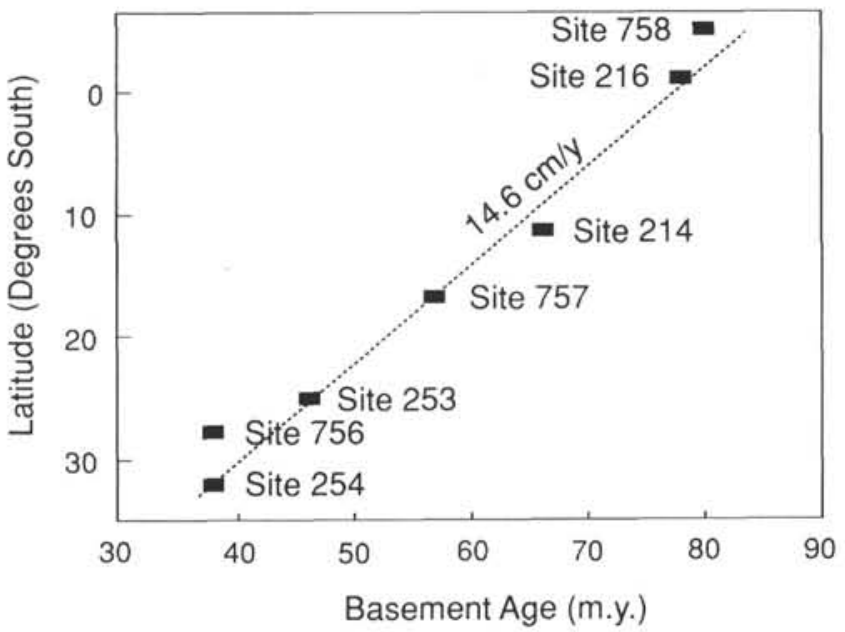

Figure 2. The relationship between basement age and distance for ODP and DSDP sites on Ninetyeast Ridge. The dotted line, corresponding to a plate migration rate of $7.8 \mathrm{~cm} / \mathrm{yr}$, is drawn by eye. 
dicted paleolatitudes of the triple junction and the measured paleolatitudes of the basalts from Ninetyeast Ridge. Essentially, any triple junction would be expected to move northward if the Antarctic Plate remained stationary, and thus the paleolatitudes of successively younger eruptives would be expected to decrease. This is not seen. Rather, the basalts of Ninetyeast Ridge appear to have erupted at one or possibly two paleolatitudes, around $43^{\circ}$ and $50^{\circ} \mathrm{S}$, which is consistent with generation above stationary or near-stationary mantle plume(s).

The plume model, originally put forward by Morgan (1972), does not propose any relationship between the relative ages of Ninetyeast Ridge and the adjacent oceanic lithosphere to the west. The results of DSDP Legs 22 and 26 and of this cruise do, however, indicate that the ridge is of similar age to the adjacent crust to the west, which in turn implies that the plume was active on or close to the spreading axis. In fact two mantle plumes have been identified as possibly being responsible for Ninetyeast Ridge. The St. Paul/Amsterdam island system is erupting basalts compositionally similar to Ninetyeast Ridge basalts (see, for example, Thompson et al., 1974; Frey et al., 1977; Ludden at al., 1980 ), and would have been positioned close to the southern end of the Ninetyeast Ridge before the initiation of seafloor spreading along the Southeast Indian Ridge. On the basis of paleomagnetic data, both Peirce (1978) and Duncan (1978) prefer the Kerguelen/Heard island hotspot. Luyendyk and Rennick (1977) proposed that both hotspots were involved in the formation of Ninetyeast Ridge and its conjugate, the Kerguelen Plateau; critical here is the concept that Ninetyeast Ridge represents a collage of magmatic products derived from two hotspots, as a result of successive traversing of the hotspots by the southeastern arm of the Central Indian Spreading Center. Basalts from St. Paul/Amsterdam islands and Kerguelen Island have different isotopic characteristics, but recent data from Heard Island, thought to be related to the same plume as Kerguelen, ranges from Kerguelento St. Paul-type values (Barling and Goldstein, 1990).

\section{SUMMARY OF BASEMENT LITHOLOGIES RECOVERED FROM NINETYEAST RIDGE}

For detailed lithological and petrographical descriptions, the reader is referred to Peirce, Weissel, et al. (1989), von der Borch et al. (1974), and Davies et al. (1974). We shall consider the sites in geographic order from south (youngest) to north (oldest). Table 1 provides a summary of geographic location and basement lithologies drilled and recovered at each site.

\section{Site 254}

This site is located at the southern end of Ninetyeast Ridge and to the south of the intersection of Ninetyeast Ridge and Broken Ridge (Fig. 1). The oldest sediments at this site give a tentative upper Eocene to lower Oligocene age (approximately $38 \mathrm{Ma}$ ). The lowermost sedimentary unit (Unit 4) comprises silty clays and silty sands with pebble conglomerates; volcaniclastic debris is abundant. The underlying basalts are fine- to medium-grained massive, amygdaloidal, and brecciated and are olivine- or plagioclase-phyric. The upper contact of the basalt is reported to be conformable with the sediments and is highly weathered. A 2-mthick section of olivine + plagioclase-phyric basalt was encountered in Unit 4, approximately $24 \mathrm{~m}$ above the main basalt succession (Kempe, 1974). Reliable paleolatitude data could not be obtained for the basalts at this site because of the poor recovery and limited number of identified flow units (Peirce et al., 1974).

\section{Site 756}

This site is located near the crest at the southern end of Ninetyeast Ridge. The oldest sediments recovered at this site are upper Eocene (approximately $38 \mathrm{Ma}$ ). This is some $10 \mathrm{~m} . \mathrm{y}$. younger than the age predicted by the hotspot model. Trace amounts of volcaniclastic debris occur in the sediments. The basalt section was drilled for about $82 \mathrm{~m}$, and a total of 16 flow units was described in Holes 756C and 756D. The basalts are predominantly aphyric or sparsely plagioclase-phyric, and are interbedded with frequently oxidized, haematite-bearing tephra horizons. The presence of oxidized tephra, and large amygdales and vesicles in the basalts, suggests that the lavas were erupted in a subaerial environment. Shore-based paleomagnetic studies indicate that the basement samples were erupted at paleolatitudes of about $43^{\circ} \mathrm{S}$ (Klootwijk et al., this volume).

\section{Site $\mathbf{2 5 3}$}

This site is located approximately $300 \mathrm{~km}$ north of Site 756. Drilling terminated in olivine-rich basalt, which lies beneath 405 $\mathrm{m}$ of mid-Eocene (approximately $46 \mathrm{Ma}$ ) vitric volcanic ash and lapilli, although it is not clear whether this basalt represents true basement. A thin basalt flow was also encountered at 219 meters below seafloor (mbsf). The poor recovery and limited number of identified flow units means that reliable paleolatitude data could not be obtained for the basalts at this site (Peirce et al., 1974).

\section{Site 757}

Drilling at Site 757 penetrated $369 \mathrm{~m}$ of sediments before encountering basaltic basement. The lowermost sedimentary unit comprises $157 \mathrm{~m}$ of basaltic volcaniclastic material with upper Paleocene (approximately 55-59 Ma) microfossils. The basalt section ( $52 \mathrm{~m}$ drilled) comprises 20 flow units of plagioclase-phyric basalt-some with more than $40 \%$ phenocrysts. The majority of the flows are vesicular and probably represent thin sheet flows. It is thought that the flows erupted in a subaerial environment, and that the overlying tephra represent phreatic (Surtseyan) eruptions.

\section{Site 214}

The lowermost sedimentary units (lignite and volcanic tephra) at this site probably represent a lagoonal/volcanic environment and were deposited during or just before the Paleocene. The basement at Site 214 comprises coarse-grained, frequently amygdaloidal basalt, although fine-grained or glassy differentiated andesites are intercalated-possibly as sills-within the oldest sediments.

\section{Site $\mathbf{2 1 6}$}

The basement at this site comprises scoriaceous and amygdaloidal chloritized basalt and is overlain by Pleistocene to late Maestrichtian nannofossil oozes and chalks, and by late Maestrichtian chalk and volcanic clay and ash beds. The estimated age of the uppermost lavas is 68-65 Ma. As with other sites from Ninetyeast Ridge, the presence of amygdales and highly oxidized basalts implies that the basalts were erupted subaerially, a suggestion borne out by the immediately overlying shallow-water sediments. A total of $16.7 \mathrm{~m}$ of volcanic rock (basalt and tuffs) were recovered at this site.

\section{Site $\mathbf{7 5 8}$}

This site is positioned on the southeast side of one of the large en-echelon blocks that characterize Ninetyeast Ridge between the equator and $10^{\circ} \mathrm{N}$. The oldest sediments recovered at Site 758 are Campanian (73-83 Ma) tuffs with minor interbeds of ashy chalk. A total of 29 basaltic flows and eight interbedded tuff units were recovered. The basalts have a uniform mineralogy and chemistry, although the upper units are massive flows (up to $20 \mathrm{~m}$ thick). The lower units are often pillowed, unlike basalts from the other Ninetyeast Ridge sites, which suggests that the flows were erupted in a deep submarine environment. 


\section{POST-MAGMATIC ALTERATION}

All of the basalts recovered from Ninetyeast Ridge have been affected by secondary alteration. In this section we evaluate the extent and nature of this alteration in order to understand the post-magmatic history of the lavas. Macroscopic studies of the cores recovered at Sites 756 and 757 reveal that the basalts have undergone pervasive low-grade alteration of two types, which we shall term "oxidative" and "non-oxidative" after the studies of Bass et al. (1973).

The oxidative alteration characteristically occurs at the margins of flow units, diffusing several tens of centimeters into the unit (e.g., Section 121-756D-6R-2), and as haloes around calcitefilled veins (e.g., Samples 121-756D-11R-2, 60-145 cm, and 121-757C-9R-1, 43-66 cm). The most obvious result of this oxidative alteration is the orange, brown, and yellow staining of the basalt caused by the formation of green/yellow smectites (including Mg-saponites?), limonite staining, and goethite in the mesostasis, fractures, and vesicles. These minerals are invariably associated with the late-stage development of calcite, particularly in fractures and vesicles. (For identification of secondary mineral phases, the reader is referred to the shipboard studies in Peirce, Weissel, et al., 1989.)

Non-oxidized portions of the cores are medium to dark grey in color. In these regions, the predominant alteration product is a blue-green or blue-grey smectite (Section 121-756D-11R-1) which again pervades the groundmass, fractures, and vesicles. Where the paragenetic sequence can be determined, the oxidative alteration tends to follow the non-oxidative alteration. Zeolites (natrolite and analcite), and opaline and chalcedonic silica, occur in vesicles, cavities, and fractures in the basalts from Hole $757 \mathrm{C}$, but no zeolites have been recorded at either Sites 756 or 758 .

Unlike the basalts from Sites 756 and 757, those from Site 758 show no evidence of oxidative alteration. Nonetheless, the basalts from Site 758 are highly altered: they show development of secondary minerals, particularly black, dark brown, and green chlorite-smectites and saponite, and sulphides, calcite, quartz, opal, and ankerite. All of these species occur in vesicles and veins; in the massive flow units from the upper part of the hole, the once-abundant mesostasis shows virtually complete replacement by clay minerals. Calcite is less abundant than in the basalts from Sites 756 and 757 .

Iddingsite and bowlingite pseudomorphs in basalts from all three sites indicate that olivine has been completely replaced; augite (groundmass or phenocrystal) is less altered. Plagioclase has undergone varying degrees of alteration, ranging from unaltered to almost complete replacement by zeolite, calcite, and clay minerals in some basalts from Hole 757C. Typically, plagioclase phenocrysts show minor replacement by pale-green clay minerals in the basalts from Sites 756 and 758 .

Not surprisingly, such pervasive alteration has affected the composition of the basalts from Sites 756, 757, and 758. Total ignition losses (i.e., $\mathrm{H}_{2} \mathrm{O}+\mathrm{CO}_{2}+$ weight change due to iron oxidation), determined after pre-drying at $120^{\circ} \mathrm{C}$, range from just under $0.5 \%$ to almost $9 \%$, despite the fact that samples were deliberately selected from the freshest parts of the core (Fig. 3). Many of the samples from Sites 756 and 758 do not show excessive ignition losses despite the petrographic evidence of alteration, but many samples from Site 757 have very high losses. These high losses may reflect the high proportion of clay- or calcitefilled vesicles unavoidably sampled during analysis. The losses also reflect the very extensive replacement of the groundmass by clay minerals.

Both $\mathrm{K}_{2} \mathrm{O}$ and $\mathrm{Rb}$ are strongly affected by the secondary alteration (Figs. 3 to 5). Their abundance varies according to the alteration state of the basalts. Thus, the visibly non-oxidized

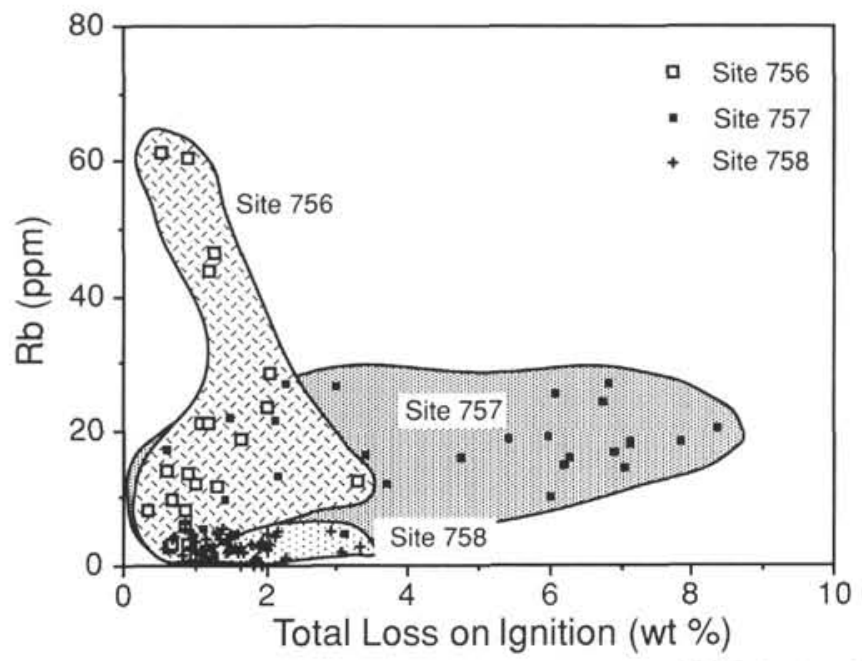

Figure 3. Abundances of Rb vs. total loss on ignition (at $600^{\circ} \mathrm{C}$ ) for basalts from Sites 756, 757, and 758, illustrating the high ignition losses in Site 757 basalts. Note that although the ignition losses in the basalts at Sites 756 and 758 are similar, there is a wide range of (secondary?) Rb contents.

portions of the cores generally have low concentrations of Rb and $\mathrm{K}$, whereas the oxidized areas have high abundances, particularly where the sample is from an oxidized region in the vicinity of a calcite vein (e.g., Sample 121-756D-7R-2, 134-137 cm, which has $61 \mathrm{ppm} \mathrm{Rb}$ ). All of the analyzed samples from Hole $758 \mathrm{~A}$ have low $\mathrm{Rb}$ and $\mathrm{K}_{2} \mathrm{O}$ contents. This observation is in agreement with shipboard studies which showed that relative to the oxidized portions of the core, the non-oxidized material has low abundances of $\mathrm{Rb}, \mathrm{K}_{2} \mathrm{O}$, and total $\mathrm{Fe}$, and higher abundances of $\mathrm{MgO}$, $\mathrm{CaO}$, and $\mathrm{Zn}$.

It is evident that all of the basalts have been involved in open-system alteration, at least during the late-stage oxidative event, and possibly also during the earlier non-oxidative event. We initially assume that the low $\mathrm{Rb}$ and $\mathrm{K}$ contents of the nonoxidized basalt are also secondary as there is no clear correlation with other, more immobile trace elements such as $\mathrm{Zr}$ (Fig. 4) and the $\mathrm{Rb} / \mathrm{Zr}$ ratio varies markedly (Fig. 6); unaltered, comagmatic basaltic suites would give approximately constant $\mathrm{Rb} / \mathrm{Zr}$ ratios.

Apart from $\mathrm{K}, \mathrm{Rb}, \mathrm{Fe}, \mathrm{Mg}, \mathrm{Ca}$, and $\mathrm{Zn}$, other elements of petrologic interest in this study show good interelement correlations (see below), suggesting that the effect of alteration on their distributions may have been slight. Both $\mathrm{Sr}$ and $\mathrm{Ba}$ show scatter on interelement diagrams (e.g., Figs. 7 and 8), but not to the same extent as $\mathrm{K}$ and $\mathrm{Rb}$. Acid-leaching of whole-rock samples results in a reduction of ${ }^{87} \mathrm{Sr} /{ }^{86} \mathrm{Sr}$ ratios, indicating exchange with high ${ }^{87} \mathrm{Sr} /{ }^{86} \mathrm{Sr}$ fluids.

Other sites drilled on Ninetyeast Ridge also recovered variably altered basalts. At Site 214, the younger differentiated basalts generally have low ignition losses except at the lower contact of the unit, although interstitial calcite occurs (Hekinian, 1974a). The lower units, comprising non-vesicular basalts and vesicular and amygdalar basalts, all have high ignition losses $(>4 \%)$. The non-vesicular basalts show replacement of some plagioclase cores, and the matrix, by chlorite and vermiculite-smectite; vermiculite also occurs in veins, small amygdales, and patches. Calcite is found in veins and in the groundmass. Although the vesicles are frequently filled by calcite with palagonite rims, the matrix of the vesicular basalts from this site has a fresh aspect except for some palagonitized zones. Flakes of secondary biotite are recorded in the lower units of Site 214. Similar styles of alteration have been described for the basalts from Site 216: 


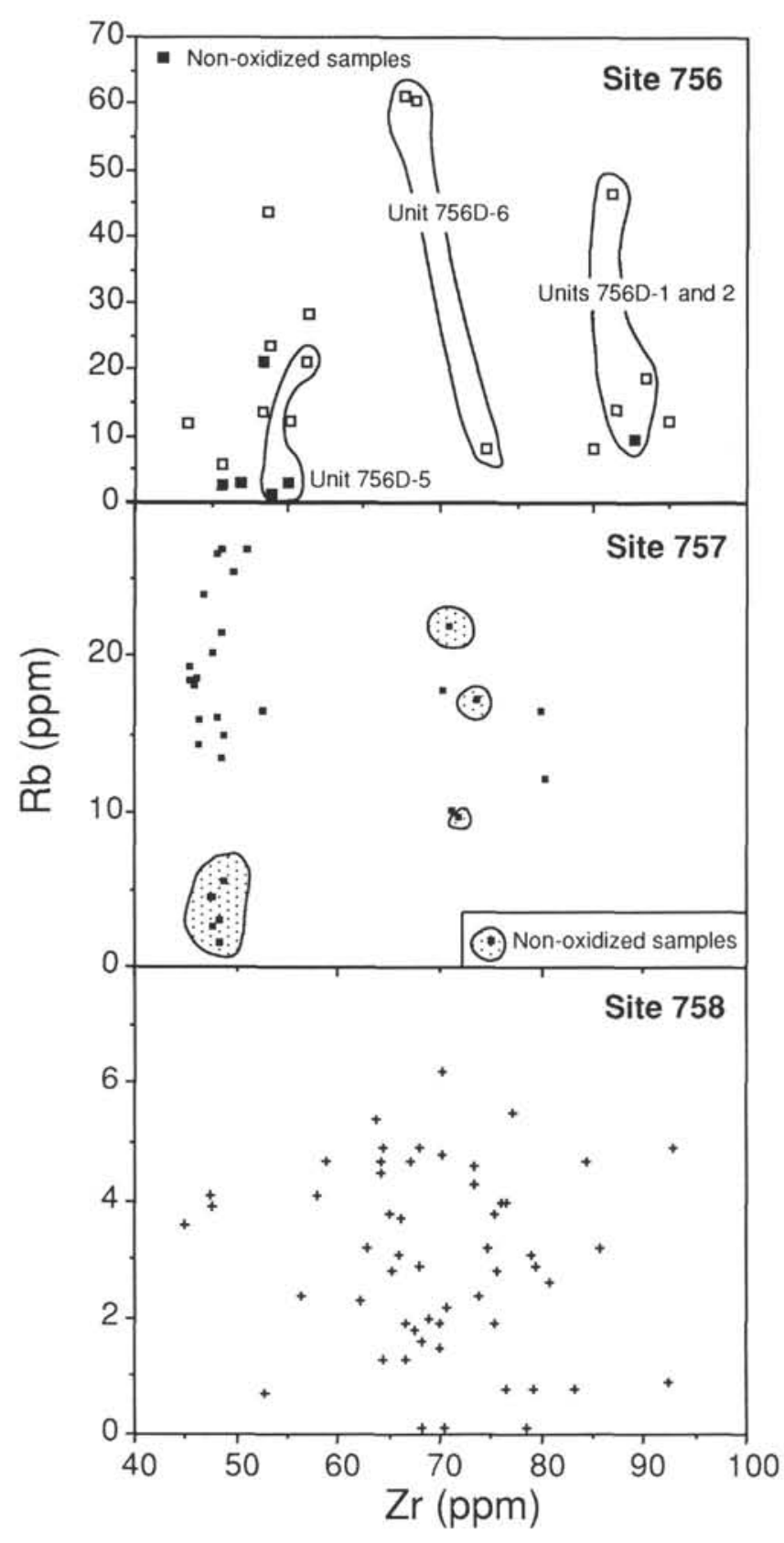

Figure 4. Abundances of $\mathrm{Rb}$ vs. $\mathrm{Zr}$ in basalts from Sites 756, 757, and 758. Note the very low abundances of Rb present at Site 758 and the wide range of $\mathrm{Rb}$ abundances in relation to the $\mathrm{Zr}$ concentration at Sites 756 and 757 . "Non-oxidized" portions of the cores recovered at Sites 756 and 757 are indicated.

vesicles filled with chlorite-smectite associations, occasional plagioclase cores replaced by clays, and iron oxides replaced by haematite (Hekinian, 1974a). Sphene granules and rutile prisms are indicated by X-ray diffraction studies.

The lowest unit of olivine-rich basalts from Site 253 shows complete replacement of olivine by serpentine and talc, although the upper, thin scoriaceous unit has preserved fresh olivines and clear volcanic glass (Kempe, 1974). Phillipsite, similar in composition and structure to authigenic phillipsite found in deep-sea sediments, occurs in the scoriaceous unit, suggesting that at least part of the alteration of these rocks occurred at near ambient,

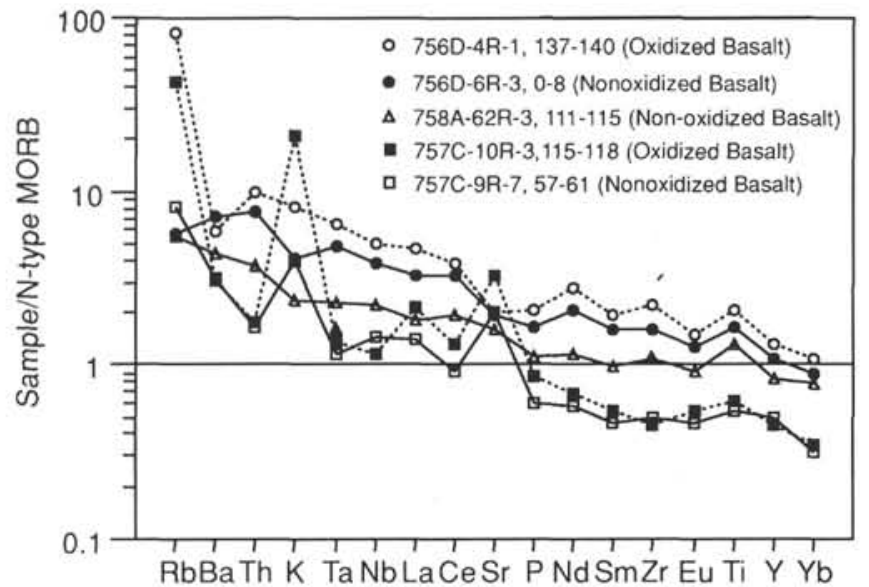

Figure 5. Abundances of the incompatible elements in basalts from Sites 756, 757 , and 758 normalized to N-type MORB. Normalizing values are from Sun and McDonough (1989). Note the high potassium abundance in the oxidized Sample 121-757C-10R-3, 115-118 cm.

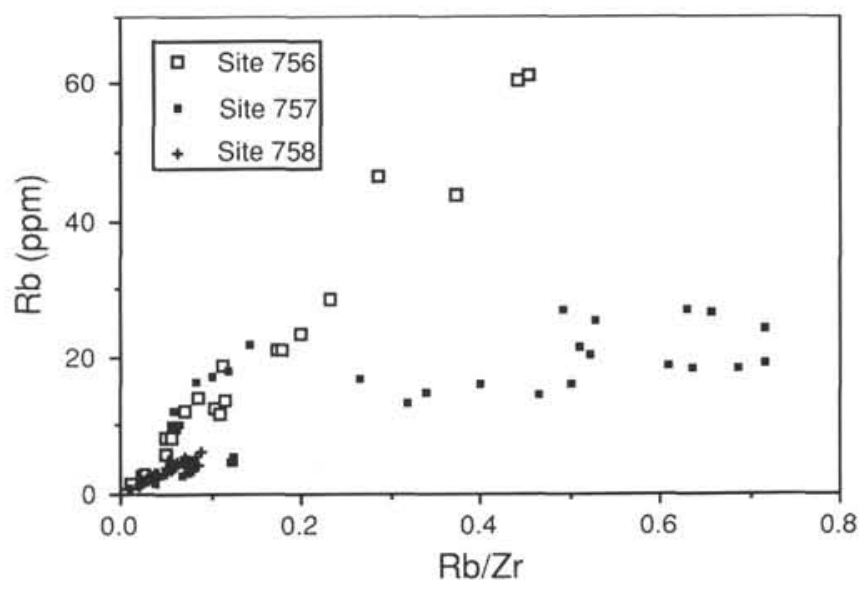

Figure 6. Abundances of $\mathrm{Rb} v \mathrm{vs}$. $\mathrm{Rb} / \mathrm{Zr}$ ratio in basalts from Sites 756,757 , and 758. The very variable $\mathrm{Rb} / \mathrm{Zr}$ ratio at all sites and the linear data array at Sites 756 and 758 are most readily interpreted in terms of Rb mobility.

abyssal temperatures. The basalts from Site 254 show alteration similar to that seen at Sites 214 and 216, with green smectites within amygdales and replacement of olivine by iddingsite.

\section{Discussion}

Without detailed reexamination of the DSDP cores, it is not possible to make comparisons between the alteration styles of the basalts from Sites 214, 216, 253, 254, 756, 757, and 758. In particular, it is not clear from the published accounts whether both the oxidative and non-oxidative alteration seen at Sites 756 and 757 also occurs in the DSDP cores. It is evident, however, that the DSDP basalts have suffered pervasive secondary alteration as have the new ODP samples. The critical questions are (1) what was the post-magmatic thermal history of these basalts and (2) in what environments did this alteration occur? Geothermometry via oxygen isotope analysis of calcite is required to answer these questions, but we note that alteration studies of drilled sequences of oceanic crust indicate that phyllosilicates, such as saponite and celadonite and calcite, are among the principal components resulting from the low-grade alteration of basalts by seawater (e.g., Andrews et al., 1980; Stakes and O'Neill, 1982; Peterson et al., 


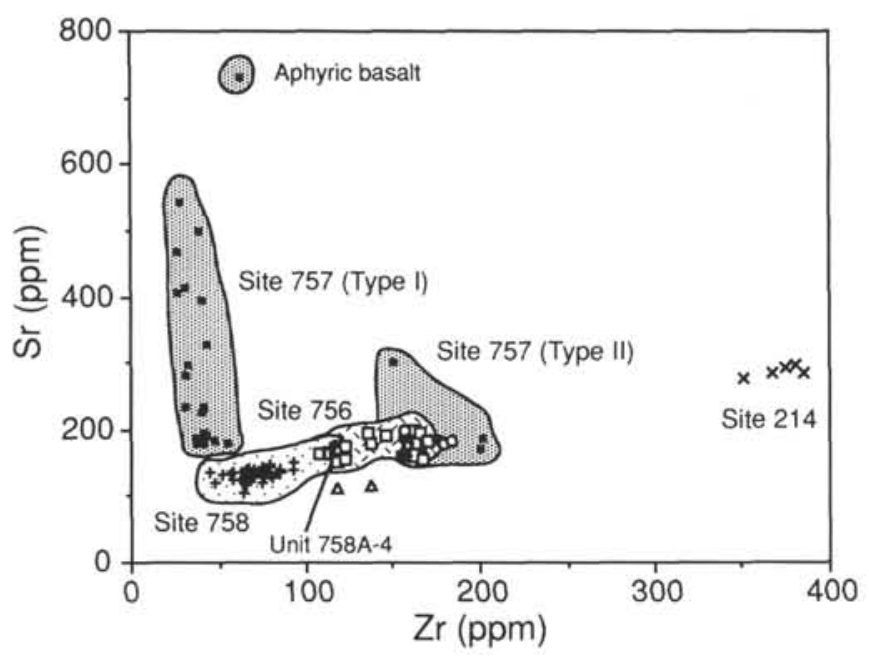

Figure 7. Abundances of $\mathrm{Sr}$ vs. $\mathrm{Zr}$ in basalts from Sites 756, 757, and 758 and DSDP Site 214. Note that the "aphyric basalt" at Site 757 is altered, with calciteand zeolite-filled vesicles. Much of the variation in the $\mathrm{Sr}$ abundances in the Type I basalts at Site 757 is probably a function of variation in the plagioclase content (see text and Fig. 16).

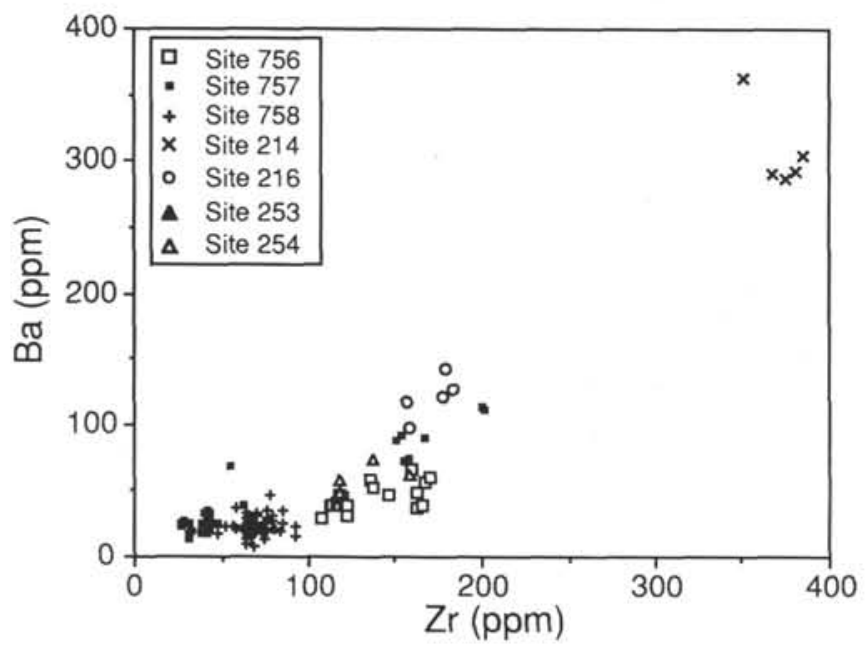

Figure 8. Abundances of Ba vs. $\mathrm{Zr}$ in basalts from Sites 756,757 , and 758 and DSDP Sites 214, 216, 253, and 254.

1986). It is widely recognized that both non-oxidative and oxidative alteration occurs in the oceanic environment (e.g., Bass, 1976), at a range of metamorphic conditions. At the one extreme, non-oxidative hydrothermal alteration occurs at temperatures in excess of $200^{\circ} \mathrm{C}$, with the formation of $\mathrm{Mg}$-chlorite- and talc-bearing assemblages, through non-oxidative and oxidative alteration at temperatures ranging from about $200^{\circ} \mathrm{C}$ to $0^{\circ} \mathrm{C}$, producing a range of secondary mineral assemblages.

With the exception of the Site 757 basalts, Ninetyeast Ridge basalts were altered at sub-zeolite grade. The mineral assemblage of yellow-green smectites, goethite, limonite, and calcite are typical of oxidative assemblages found in ocean-floor basalts from the east Pacific (e.g., Site 597: Peterson et al., 1986; Hole 504B: Alt et al., 1986) and mid-Atlantic (e.g., Leg 37 basalts: Andrews et al., 1980). The temperature of formation of this assemblage probably ranges from $170^{\circ} \mathrm{C}$ and down to ambient, although no celadonite has been reported in the cores from any of Ninetyeast Ridge sites. Ambient alteration might be indicated at Site 253 by the development of phillipsite (cf. Bohkle et al., 1980). The non-oxidative alteration, indicated by dark brown or blue smectites, invariably occurs before the oxidative alteration, but there are no indications that the thermal grade during the non-oxidative event was greater than during the oxidative event. The main variable may have been the water-rock ratios operating at the time of the alteration: high during the oxidative event, low during the non-oxidative. The distribution of the oxidative alteration at flow margins and along fractures supports this suggestion. Further work is required to constrain the temperatures of alteration.

In the ocean-ridge environment, the top of the recently formed basalt pile may be altered by seawater percolating into the pile (i.e., in the downwelling limb of a convection system). Under these conditions, the alteration is water-dominated and oxidative. As the basalt pile becomes buried by successive flows, the hydrothermal regime changes into a rock-dominated non-oxidative system. This would account for the observation that in many sections of the ocean crust, the oxidative alteration precedes the non-oxidative. Clearly, Ninetyeast Ridge is atypical, and an alternative model is required. One suggestion is that lava pile was building close to the source of heat and would therefore initially sit on an upwelling hydrothermal limb in a non-oxidizing environment. Only when the source of heat decayed would it become a water-dominated system.

It is difficult to account for the behavior of the alkali elements, particularly $\mathrm{Rb}$, in Ninetyeast Ridge samples. Basically, what process is responsible for the low contents of $\mathrm{K}$ and $\mathrm{Rb}$ in the non-oxidized portions of the core? Do these low contents reflect low primary concentrations, or have the alkali elements been subsequently removed? As mentioned above, the lack of correlation with less-mobile elements indicates that $\mathrm{Rb}$ and $\mathrm{K}$ have migrated through the rock, but the extent of wholesale stripping is unclear. Fresh tholeiitic basalts from similar environments (e.g., Iceland or Galapagos Islands) do not exhibit the extremely low $\mathrm{Rb}$ contents and $\mathrm{Rb} / \mathrm{Zr}$ ratios observed in many of the basalts from Site 758 .

\section{ANALYTICAL TECHNIQUES}

\section{Sample Preparation}

Samples selected from the ODP and DSDP cores were rinsed in distilled water, dried, and then crushed prior to grinding in an agate Tema swing mill. Aliquots of powder or chips were taken from the samples for isotope analysis at the Open University, for neutron activation analysis (NAA) at Durham, and for inductively coupled optical-emission plasma spectrometry (ICP) and X-ray fluorescence (XRF) analyses at Leicester.

\section{XRF Analysis}

Rocks were crushed to finer than $200-\mu \mathrm{m}$ mesh and made into powder briquettes for trace-element analysis, and fused with lithium metaborate/lithium tetraborate flux in the proportion of 1 rock to 5 flux by mass for major element analysis. Analysis was performed using rhodium- and tungsten-anode tubes on a wavelength-dispersive Philips PW1400 X-ray spectrometer at the University of Leicester. Loss on ignition (LOI) was determined by pre-drying at $120^{\circ} \mathrm{C}$, followed by heating to $800^{\circ} \mathrm{C}$ in air. Analyses are not recalculated on a hydrous basis, as the ignition losses for several units are very high. Analyses of International Standard W1 are included in Table 2. Agreement with shipboard results is generally excellent. 
Table 2. International and laboratory standard data.

\begin{tabular}{|c|c|c|c|}
\hline & $\underset{\text { (mean) }}{\mathrm{W}-1}$ & 1-sigma & Recommended $^{\mathrm{a}}$ \\
\hline \multicolumn{4}{|c|}{ Major element data (XRF) } \\
\hline $\mathrm{SiO}_{2}$ & 52.08 & 0.58 & 52.74 \\
\hline $\mathrm{TiO}_{2}$ & 1.075 & 0.01 & 1.08 \\
\hline $\mathrm{Al}_{2} \mathrm{O}_{3}$ & 14.87 & 0.11 & 15.08 \\
\hline $\mathrm{Fe}_{2} \mathrm{O}_{3}$ & 11.07 & 0.04 & 11.17 \\
\hline $\mathrm{MnO}$ & 0.17 & 0.006 & 0.17 \\
\hline $\mathrm{MgO}$ & 6.64 & 0.11 & 6.64 \\
\hline $\mathrm{CaO}$ & 10.94 & 0.08 & 11.06 \\
\hline $\mathrm{Na}_{2} \mathrm{O}$ & 2.2 & 0.08 & 2.17 \\
\hline $\mathrm{K}_{2} \mathrm{O}$ & 0.628 & 0.008 & 0.643 \\
\hline $\mathrm{P}_{2} \mathrm{O}_{5}$ & 0.141 & 0.009 & 0.131 \\
\hline \multirow[t]{2}{*}{ Total } & 99.814 & & 100.884 \\
\hline & Mean & 1-sigma & Recommended $\mathrm{b}^{\mathrm{b}}$ \\
\hline
\end{tabular}

Trace element data (XRF)

\begin{tabular}{lrlclll}
$\mathrm{Nb}$ & 7.4 & 0.62 & 9.9 & & \\
$\mathrm{Zr}$ & 94.7 & 0.9 & 99 & & \\
$\mathrm{Y}$ & 22.7 & 0.6 & 26 & & \\
$\mathrm{Sr}$ & 188.7 & 1.4 & 186 & & \\
$\mathrm{Rb}$ & 23 & 1 & 21.4 & & \\
$\mathrm{Th}$ & 4.8 & 1 & 2.4 & & \\
$\mathrm{Ga}$ & 20.1 & 1.3 & 17.4 & & \\
$\mathrm{Zn}$ & 90 & 1 & 84 & & \\
$\mathrm{Ni}$ & 71.9 & 1.9 & 75 & & \\
$\mathrm{~V}$ & 241.8 & 3.4 & 257 & & \\
$\mathrm{Cr}$ & 130.7 & 2.1 & 119 & & \\
$\mathrm{Ba}$ & 162.4 & 1.7 & 162 & & \\
$\mathrm{La}$ & 11.8 & 0.9 & 11 & & \\
$\mathrm{Ce}$ & 22.5 & 1.9 & 23.5 & & \\
$\mathrm{Nd}$ & 9.6 & 2.5 & 14.6 & & \\
& & & & & & \\
\hline & $\mathrm{BR}$ & BR & BR & BOB-1 & BOB-1 $^{\mathrm{B}}$ & BOB-1 $^{\mathrm{f}}$ \\
& $(1)^{\mathrm{c}}$ & $(2)^{\mathrm{d}}$ & $(3)^{\mathrm{e}}$ & $(1)^{\mathrm{f}}$ & $(2)^{\mathrm{g}}$ & $(3)^{\mathrm{h}}$ \\
\hline
\end{tabular}

Trace element data (NAA and ICP)

\begin{tabular}{lcccccc}
$\mathrm{La}$ & 85 & 80 & 85 & 5.5 & 4.5 & 4.72 \\
$\mathrm{Ce}$ & 163 & 140 & 152 & 15 & 13.2 & 13.76 \\
$\mathrm{Pr}$ & - & - & - & $-\overline{-}$ & 1.9 & \\
$\mathrm{Nd}$ & 71 & 60 & 68 & 10.2 & 9.8 & 10.7 \\
$\mathrm{Sm}$ & 12.4 & 12 & 11.9 & 3.25 & 3.37 & 3.32 \\
$\mathrm{Eu}$ & 3.67 & 3.7 & 3.56 & 1.05 & 1.2 & 1.25 \\
$\mathrm{Gd}$ & - & - & - & 4.1 & 4.23 & 4.16 \\
$\mathrm{~Tb}$ & 1.37 & - & 1.31 & 0.712 & $-\overline{-}$ & 0.74 \\
$\mathrm{Dy}$ & - & - & - & - & 4.48 & - \\
$\mathrm{Er}$ & - & - & - & - & 2.06 & - \\
$\mathrm{Ho}$ & $\overline{-}$ & - & - & 0.99 & - & - \\
$\mathrm{Yb}$ & 1.75 & 2 & 1.88 & 2.62 & 2.54 & 2.63 \\
$\mathrm{Lu}$ & 0.23 & - & 0.28 & 0.379 & 0.3771 & 0.44 \\
$\mathrm{Ta}$ & 5.54 & - & 6.6 & 0.44 & - & 0.45 \\
$\mathrm{Hf}$ & 5.9 & - & 5.3 & 2.19 & - & 2.53 \\
$\mathrm{Th}$ & 10.9 & 12 & 11 & 0.33 & - & 0.51 \\
$\mathrm{U}$ & 2.3 & 3 & - & 0.1 & - & - \\
$\mathrm{W}$ & 1.6 & - & - & 142 & - & - \\
$\mathrm{Sc}$ & 23.2 & 26 & 23 & 33.2 & - & - \\
\hline
\end{tabular}

Note: Dashes $=$ not analyzed.

a Data recalculated anhydrous and fully oxidized from Govindaraju (1989) precision data based on four replicate fusion beads.

b Values from Govindaraju (1989). Precision data from five replicate analyses of one sample pellet.

c Laboratory values for International Standard BR reported by Leat et al. (1990).

d Recommended and proposed values for BR from Govindaraju (1984).

e Published values for BR from Prudencio et al. (1986).

${ }^{f}$ Values for ocean floor basalt standard BOB-1 reported by Durham NAA laboratory.

${ }^{8}$ Mean of five analyses of BOB-1 by ICP analysis at Leicester University.

$\mathrm{h}$ Mean values of BOB-I determined at London University by ADS between 1980 and 1984

\section{ICP Analysis}

Simultaneous analysis of rare earth elements was carried out using a Philips PV8060 ICP emission spectrometer at the University of Leicester. Sample preparation involved the standard HF$\mathrm{HClO}_{4}$ attack followed by dissolution in $\mathrm{HCl}$ (Walsh et al., 1981). An internal standard basalt, BOB-1, was run with every six samples to monitor analytical precision and accuracy. These results are included in Table 2.

\section{Neutron Activation Analysis}

Samples of material (crushed in agate to avoid Ta contamination) were analyzed by neutron activation at the University of Durham. Analytical techniques are described by Leat et al. (1990), except that the samples were each counted for $24 \mathrm{hr}$, rather than for $5400 \mathrm{~s}$. Data for International Standard BR are included in Table 2, together with data for standard BOB-1 to enable crossreference with ICP data.

\section{Microprobe Analysis}

Mineral analysis were performed using a JEOL 8600 S wavelength-dispersive microprobe with three automated crystal spectrometers. The electron beam was operated at an accelerating voltage of $15 \mathrm{kV}$ and a probe current of $30 \mathrm{nA}$ with a diameter of $5 \mu \mathrm{m}$. This was increased to $10 \mu \mathrm{m}$ to minimize damage when analyzing beam-sensitive feldspars. X-ray intensities were standardized against a range of pure elements, synthetic oxides, and natural minerals. Dead-time and background corrections were applied to the X-ray intensities followed by ZAF correction to the measured oxide concentrations.

\section{Isotope Analysis}

To assess the possible effects of seawater alteration on the $\mathrm{Sr}$ isotopic compositions of Ninetyeast Ridge basalts, a number of samples were subjected to a multi-step acid-leaching process similar to the one employed by Mahoney (1987). For altered ocean-floor tholeiites, it has been shown (e.g., Mahoney, 1987) that this technique is successful in removing low-temperature phases, leaving a residue of mainly plagioclase and clinopyroxene which gives near-magmatic $\mathrm{Sr}$ isotopic compositions.

For rock powders, $\mathrm{Pb}$ isotopic compositions were also measured on leached samples so as to remove any contamination introduced during the crushing process. The leaching procedure consisted of adding ultrapure $6 \mathrm{M} \mathrm{HCl}$ to $\sim 1 \mathrm{~g}$ of rock powder in a Teflon bomb. The bomb was sealed and placed in an ultrasonic bath for approximately $10 \mathrm{~min}$ before putting on a hotplate for several hours. The solution was drained off, the residue being rinsed with ultrapure $\mathrm{H}_{2} \mathrm{O}$, before adding further $\mathrm{H}_{2} \mathrm{O}$ and placing the mixture in an ultrasonic bath. This $\mathrm{HCl}-\mathrm{H}_{2} \mathrm{O}$ cycle was repeated several times until the acid remained colorless and clear. In addition to the residues, the leachates from two samples were collected and analyzed for $\mathrm{Sr}$ isotopic compositions. Comparison of unleached, leached, and leachate samples are shown in Table 11.

Powders and rock chips were dissolved using a $\mathrm{Hf}-\mathrm{HNO}_{3}$ mixture; residues were converted to nitrates and finally chloride. $\mathrm{Pb}$ was separated using a microcolumn technique described in Palacz and Saunders (1986), for which the total procedural $\mathrm{Pb}$ blank was less than 0.5 nanograms. $\mathrm{Sr}$ and $\mathrm{Nd}$ were separated using conventional ion-exchange procedures.

Isotopic compositions were measured on a MAT 261 multicollector mass spectrometer at the Open University. ${ }^{87} \mathrm{Sr} /{ }^{86} \mathrm{Sr}$ ratios were fractionation-corrected to ${ }^{87} \mathrm{Sr} /{ }^{86} \mathrm{Sr}=0.1194$; Nd isotopic ratios were corrected to ${ }^{146} \mathrm{Nd} /{ }^{144} \mathrm{Nd}=0.7219$ and normalized to ${ }^{143} \mathrm{Nd} /{ }^{144} \mathrm{Nd}=0.511836$ for J\&M standard, which corresponds to a BCR-1 value of 0.512638 . The laboratory average for NBS-987 
is ${ }^{87} \mathrm{Sr} /{ }^{86} \mathrm{Sr}=0.71023$. Errors for $\mathrm{Sr}$ and $\mathrm{Nd}$ data are 2-sigma within-run errors. Isotopic compositions of $\mathrm{Pb}$ were corrected for mass fractionation relative to recommended NBS-981 standard values of ${ }^{206} \mathrm{~Pb} /{ }^{204} \mathrm{~Pb}=16.937,{ }^{207} \mathrm{~Pb} /{ }^{204} \mathrm{~Pb}=15.491$, and ${ }^{208} \mathrm{~Pb} /{ }^{204} \mathrm{~Pb}=36.721$. Estimated uncertainties are ${ }^{206} \mathrm{~Pb} /{ }^{204} \mathrm{~Pb} \pm$ $0.020,{ }^{207} \mathrm{~Pb} / 204 \mathrm{~Pb} \pm 0.020$, and ${ }^{208} \mathrm{~Pb} /{ }^{204} \mathrm{~Pb} \pm 0.060$.

\section{IGNEOUS MINERALOGY}

A small selection of samples from Sites 756,757 , and 758 has been analyzed by electron microprobe to determine the compositions of the main mineral phases. The purpose of this exercise is to provide data with which to model major element whole-rock fractionation trends, rather than a detailed study of the minerals themselves. Consequently, the following sections will be limited to brief descriptions to accompany the representative data in Tables 3 to 5 .

\section{Site 756}

A series of plagioclase feldspars, ranging from small groundmass laths to larger (ca. $500 \mu \mathrm{m}$ ) corroded phenocrysts, has been analyzed in Sample 121-756D-6R-2, 125-128 cm (Table 3). Anorthite content ranges from $67 \%$ to $87 \%$, but there is not a systematic variation with crystal type: the most calcic feldspar compositions occur in subhedral feldspar phenocrysts (An80 to An87), rather than in the corroded phenocrysts ( $\mathrm{An}_{77}$ to $\mathrm{An}_{82}$ ). Where analyzed, the edge feldspar is generally not the most sodic, which is unusual.

\section{Site 757}

Petrographically, the lavas recovered at Site 757 exhibit a complex history of plagioclase crystallization. We have analyzed a series of feldspars, ranging from large $(>1 \mathrm{~cm}$ diameter) megacrysts, to groundmass laths, in Samples 121-757C-9R-1, 15-19 cm (lithological Unit 2); 121-757C-10R-2, 98-102 cm (lithological Unit 7); 121-757C-11R-2, 128-132 cm (lithological Unit 14); 121-757C-12R-1, 39-43 cm (lithological Unit 18); and 121-757C-12R-4, 74-78 cm (lithological Unit 18) (see Table 3). The narrow rims of the phenocrysts comprise sodic feldspars similar in composition to the groundmass laths; some contain a high proportion of potassic feldspar. The cores of the larger phenocrysts have a limited range of compositions, from An80 to Ango.

Several groundmass feldspars and, in one case, a core-area in a large plagioclase phenocryst (analysis 13 , Table 3 ) were initially identified as plagioclase but turn out to be potassium feldspars. These feldspars form only a minor component in these rocks; it is not clear if the feldspar is of primary or secondary origin.

Lavas from the lower part of Hole $757 \mathrm{C}$ contain small quantities of pyroxene phenocrysts (less than $5 \%$ by volume). Pyroxenes were analyzed in Samples 121-757C-11R-2, 128-132 cm (lithological Unit 14), and 121-757C-12R-1, 39-43 cm (lithological Unit 18). Despite the fact that these two samples are from distinct chemical units (see below), there is no discernible difference in composition of their pyroxenes (Table 4). All are high-calcium pyroxenes falling within the field of diopside; $\mathrm{Al}_{2} \mathrm{O}_{3}$ contents range between $2 \%$ and $3 \%$. There is no obvious chemical zoning of individual grains.

Most of the larger plagioclase phenocrysts in the Hole 757C basalts contain dark brown inclusions, often arranged in concentric zones parallel to the rim of the crystal. In some crystals, several successive layers of inclusions can be seen. We have not carried out an exhaustive study of these inclusions but a representative set of analyzes is included in Table 5. The size of the inclusions ranges from 10 to $40 \mu \mathrm{m}$. The results indicate that the inclusions represent trapped basaltic liquid from which feldspar components have been extracted. This has resulted in enrichment in non-feldspar oxides (i.e., $\mathrm{TiO}_{2}, \mathrm{FeO}, \mathrm{MgO}, \mathrm{Cr}_{2} \mathrm{O}_{3}, \mathrm{MnO}$, and $\mathrm{P}_{2} \mathrm{O}_{5}$ ), but the range of $\mathrm{FeO} / \mathrm{MgO}$ ratios suggests that the liquids were trapped at various stages of differentiation. Unfortunately, no inclusions could be seen in pyroxenes which could allow back-calculation of the composition of the parental melts.

\section{Site 758}

Apart from Unit 4 in Hole 758A, which is highly plagioclasephyric, the lavas recovered at Site 758 are only sparsely plagioclase-phyric, or aphyric. Feldspars in two samples have been analyzed for the present study: 121-758A-61R-6, 11-15 cm (lithological Unit 3), and 121-758A-62R-1, 82-87 cm (lithological Unit 4). One analyzed phenocryst from Unit 3 ranges in composition from An82 to An86, with a well-developed sodic rim (An56). The plagioclase from Unit 4 also has sodic rims (An63), but the cores are more calcic than those from Unit 3 (up to An88). This concurs with the primitive composition of this basalt (see below).

Small pyroxene phenocrysts occur in several units from Hole 758A and were analyzed in Samples 121-758A-58R-3, 144-148 $\mathrm{cm}$ (lithological Unit 2), 121-757C-67R-4, 142-146 cm (lithological Unit 15), and 121-758A-69R-2, 70-74 cm (lithological Unit 17). All of the pyroxenes are high-Ca varieties, falling in the field of diopside and augite, and overlap with the compositions determined for Site 757 pyroxenes. $\mathrm{Cr}_{2} \mathrm{O}_{3}$ contents are variable but tend to be lower than those determined in the Site 757 pyroxenes. There is considerable range of $\mathrm{FeO} / \mathrm{MgO}$ ratio (Table 4) both within individual grains and between different samples.

\section{ELEMENTAL AND ISOTOPIC DATA}

Whole-rock geochemical data for basalts from Sites 756, 757, $758,214,216,253$, and 254 are presented in Tables 6 to 9 (microfiche, back pocket) and Table 10, and the new isotopic data in Table $11 .^{7}$ We briefly describe the data using these tables and a series of representative plots before discussing the overall geochemistry of the rocks. We begin with the latest ODP sites.

\section{Site 756}

The basalts from Site 756 are moderately evolved olivinetholeiites (one of the more evolved units, Unit 5 in Hole $756 \mathrm{D}$, is mildly quartz-normative), with $\mathrm{FeO} / \mathrm{MgO}$ ratios ranging from 1.2 to 2.3 (Table 6 , microfiche, back pocket). There is a tendency for the uppermost units ( 1 and 2 ) in Hole 756D to be more evolved, although evolved units do occur lower in the succession (Unit 10). Samples from Hole $756 \mathrm{C}$ may be compositionally matched with those from the upper part of Hole 756D so they will not be considered separately here.

Considered as a whole, the basalts from Site 756 show Fe-enrichment (Fig. 9), which is consistent with their tholeiitic nature. $\mathrm{Na}_{2} \mathrm{O}$ ranges from $2.2 \%$ to $3.0 \%$. However, abundances of $\mathrm{Na}_{2} \mathrm{O}$, like those of other alkali oxides, have probably been affected by post-magmatic alteration, however. Certainly, $\mathrm{K}_{2} \mathrm{O}$ shows no systematic variation with any index of fractionation.

$\mathrm{Al}_{2} \mathrm{O}_{3}$ shows no significant change with increasing $\mathrm{FeO}$ (Fig. 10 ), suggesting that there was not a high proportion of plagioclase in the fractionating mineral assemblage, although the data points show only a weak clustering.

The moderate $\mathrm{FeO} / \mathrm{MgO}$ ratios and the low Ni contents $(60$ $106 \mathrm{ppm}$ ) of these basalts indicate that they represent non-primary liquids. Both $\mathrm{Ni}$ and $\mathrm{Cr}$, however, show very poor correlations with $\mathrm{FeO} / \mathrm{MgO}$ ratios. Although this may be due in part to secondary mobilization of $\mathrm{Fe}$, it is noteworthy that the correlations are

\footnotetext{
${ }^{7}$ All data are available on diskette from the first author upon request.
} 
Table 3. Analyses of feldspars, Sites 756, 757, and 758.

\begin{tabular}{|c|c|c|c|c|c|c|c|c|c|c|c|}
\hline \multirow{2}{*}{$\begin{array}{l}\text { Sample } \\
\text { Analysis number }^{\mathrm{a}}\end{array}$} & \multicolumn{6}{|c|}{$121-756 \mathrm{D}-6 \mathrm{R}-2,125-128 \mathrm{~cm}$} & \multicolumn{5}{|c|}{$121-757 \mathrm{C}-11 \mathrm{R}-2,128-132 \mathrm{~cm}$} \\
\hline & 1 & 2 & 3 & 4 & 5 & 6 & 7 & 8 & 9 & 10 & 11 \\
\hline $\mathrm{SiO}_{2}$ & 47.22 & 48.62 & 48.99 & 48.19 & 46.83 & 48.06 & 46.87 & 46.18 & 64.22 & 46.42 & 45.72 \\
\hline $\mathrm{Al}_{2} \mathrm{O}_{3}$ & 32.98 & 32.25 & 32.05 & 32.53 & 33.56 & 32.63 & 33.15 & 33.67 & 18.04 & 33.47 & 33.45 \\
\hline $\mathrm{Fe}_{2} \mathrm{O}_{3}$ & 0.52 & 0.63 & 0.64 & 0.62 & 0.53 & 0.58 & 0.57 & 0.52 & 0.08 & 0.56 & 0.5 \\
\hline $\mathrm{CaO}^{3}$ & 17.56 & 16.36 & 15.79 & 16.67 & 17.59 & 16.65 & 17.35 & 17.94 & 0 & 17.68 & 18.02 \\
\hline $\mathrm{Na}_{2} \mathrm{O}$ & 1.75 & 2.34 & 2.57 & 2 & 1.5 & 2.13 & 1.65 & 1.27 & 0.19 & 1.47 & 1.11 \\
\hline $\mathrm{K}_{2} \mathrm{O}$ & 0.03 & 0.03 & 0.06 & 0.02 & 0.03 & 0.03 & 0.02 & 0.02 & 16.23 & 0.01 & 0 \\
\hline Total & 100.06 & 100.23 & 100.1 & 100.03 & 100.04 & 100.08 & 99.61 & 99.6 & 98.76 & 99.61 & 98.8 \\
\hline $\mathrm{O}$ & 32 & 32 & 32 & 32 & 32 & 32 & 32 & 32 & 32 & 32 & 32 \\
\hline $\mathrm{Si}$ & 8.691 & 8.901 & 8.968 & 8.842 & 8.617 & 8.819 & 8.66 & 8.545 & 12.02 & 8.585 & 8.529 \\
\hline Al & 7.155 & 6.959 & 6.915 & 7.035 & 7.278 & 7.057 & 7.219 & 7.343 & 3.98 & 7.296 & 7.355 \\
\hline $\mathrm{Fe}_{3}$ & 0.072 & 0.087 & 0.088 & 0.086 & 0.073 & 0.08 & 0.079 & 0.072 & 0.011 & 0.078 & 0.07 \\
\hline $\mathrm{Ca}$ & 3.463 & 3.209 & 3.097 & 3.277 & 3.468 & 3.274 & 3.435 & 3.557 & 0 & 3.504 & 3.602 \\
\hline $\mathrm{Na}$ & 0.625 & 0.831 & 0.912 & 0.712 & 0.535 & 0.758 & 0.591 & 0.456 & 0.069 & 0.527 & 0.402 \\
\hline K & 0.007 & 0.007 & 0.014 & 0.005 & 0.007 & 0.007 & 0.005 & 0.005 & 3.876 & 0.002 & 0 \\
\hline Sum & 20.013 & 19.994 & 19.994 & 19.957 & 19.978 & 19.995 & 19.989 & 19.978 & 19.956 & 19.992 & 19.958 \\
\hline An & 84.6 & 79.3 & 77 & 82.1 & 86.5 & 81.1 & 85.2 & 88.5 & 0 & 86.9 & 90 \\
\hline $\mathrm{Ab}$ & 15.3 & 20.5 & 22.7 & 17.1 & 13.3 & 18.8 & 14.7 & 11.3 & 1.7 & 13.1 & 10 \\
\hline Or & 0.2 & 0.2 & 0.3 & 0.1 & 0.2 & 0.2 & 0.1 & 0.1 & 98.3 & 0.1 & 0 \\
\hline
\end{tabular}

${ }^{\mathrm{a}} \mathrm{Key}$ to analysis numbers:

1, 2 = plagioclase microphenocryst laths;

$3,4=$ corroded $500-\mu \mathrm{m}$ plagioclase phenocryst;

5 = plagioclase microphenocryst (rim);

6 = plagioclase microphenocryst (core);

7 = large plagioclase phenocryst (rim);

8 = large plagioclase phenocryst (core);

$9=300-\mu \mathrm{m} \mathrm{K}$-feldspar lath;

10 = large phenocryst aggregate;

11 = large plagioclase phenocryst;

$12,15=$ rim of large zoned plagioclase phenocryst lath;

13,14 = rim of large zoned plagioclase phenocryst lath (core region; note that analysis 13 is a $\mathrm{K}$-feldspar);

16 = zoned plagioclase lath (core area);

17 = groundmass feldspar;

18 = plagioclase phenocryst (near rim);

19,20 = plagioclase phenocryst (core area);

$21=$ plagioclase phenocryst (rim);

22 = plagioclase phenocryst (core).

not improved significantly by plotting $\mathrm{Ni}$ or $\mathrm{Cr}$ against a more immobile element such as $\mathrm{Zr}$ (Figs. 11 and 12).

$\mathrm{Zr}$, which behaves incompatibly in many basalt systems, ranges in abundance from 111 to $165 \mathrm{ppm}$, with a marked increase toward the top of the hole. Other minor and trace elements such a Ti, P, Th, Nb, Y, Ta, Hf, Y, REE, and V also behave incompatibly, with systematic correlations between element pairs. This systematic behavior is clearly demonstrated by the multi-element diagram, or spidergram (Fig. 13). Note that the samples do not show pronounced anomalies at $\mathrm{Nb}$ and $\mathrm{Ta}$, like some ocean island basalts (e.g., Palacz and Saunders, 1986).

$\mathrm{Ti} / \mathrm{Zr}$ ratios (94 to 110$)$ are similar to values found in midocean ridge basalts (MORB), but there is a decrease in $\mathrm{Ti} / \mathrm{Zr}$ ratio with increasing $\mathrm{Zr}$ (Fig. 14). This decrease is also seen in the basalts from the other Ninetyeast Ridge sites. $\mathrm{P} / \mathrm{Zr}$ ratios cluster around 7 (Table 10). Ti/V ratios are higher in the Site 756 basalts than those from the other sites (Table 10). Sc abundances vary from about 40 to $50 \mathrm{ppm}$, values similar to those in found in $\mathrm{MORB}$, and although the $\mathrm{Sc} / \mathrm{Zr}$ ratio decreases with increasing fractionation (Fig. 14), these high Sc values support the observations from the REE data that these basalts did not finally equilibrate with a garnet-bearing residue.

All of the basalts are light REE-enriched (Fig. 15), with $\mathrm{La}_{\mathrm{n}} / \mathrm{Yb}_{\mathrm{n}}$ ranging from 1.9 to 2.4 . Note that the patterns are essentially subparallel, which bears out the observations on the spidergrams, and which is supported by the colinear distribution of La vs. Yb. There are no Eu anomalies.
$\mathrm{Sr}$ is an element which may be sequestered into plagioclase feldspar. In the Site 756 basalts, however, it shows a positive correlation with $\mathrm{Zr}$ (Fig. 7) and surprisingly, despite the relative ease with which this element can be affected by hydrothermal alteration, it shows a tight clustering. The distribution of $\mathrm{Sr}$ and $\mathrm{Al}_{2} \mathrm{O}_{3}$ (Figs. 7 and 16), and the absence of negative Eu anomalies in the REE diagrams, shows that there has been little removal of plagioclase during the evolution of these basalts.

The colinear or near-colinear relationships between the different element pairs allows precise determination of the element ratios in the Site 756 basalts. These include $\mathrm{Zr} / \mathrm{Nb}=12$ to 15 , $\mathrm{La}_{\mathrm{n}} / \mathrm{Yb}_{\mathrm{n}}=1.9$ to $2.4, \mathrm{Zr} / \mathrm{Y}=3.6$ to $5.3, \mathrm{La} / \mathrm{Ta}=11.4$ to 13.4 , $\mathrm{Th} / \mathrm{Ta}=1.1$ to 1.6 , and $\mathrm{Ba} / \mathrm{Nb}=3.6$ to 5.4 (Figs. 17 and 18 ; Table $10)$. We shall return to these ratios later in this chapter; suffice it to say here that these ratios are indicative of-but do not provederivation of the melts from a mantle source with elevated abundances of highly-incompatible elements such as $\mathrm{Th}, \mathrm{Ta}, \mathrm{Nb}$, and light REE. The distribution of data in the Site 756 basalts is probably consistent with high-level removal of olivine, pyroxene, and perhaps minor plagioclase, although the poor correlations between $\mathrm{Ni}, \mathrm{Cr}$, and $\mathrm{FeO} / \mathrm{MgO}$ (or $\mathrm{Zr}$ ) make precise modeling difficult. However, the slight decrease in the $\mathrm{Ti} / \mathrm{Zr}$ ratio and $\mathrm{Sc} / \mathrm{Zr}$ ratio with increasing evolution of the melt suggests removal of small proportions of clinopyroxene. Recall, however, that these basalts are virtually aphyric.

Two samples from Site 756 have been analyzed for $\mathrm{Nd}$ isotopes (Figs, 19 and 20), giving ${ }^{143} \mathrm{Nd} /{ }^{144} \mathrm{Nd}$ ratios of 0.512829 and 
Table 3 (continued).

\begin{tabular}{|c|c|c|c|c|c|c|c|c|c|c|c|c|}
\hline \multirow{2}{*}{$\begin{array}{l}\text { Sample } \\
\text { Analysis number }^{\mathrm{a}}\end{array}$} & \multicolumn{6}{|c|}{$121-757 \mathrm{C}-12 \mathrm{R}-1,39-43 \mathrm{~cm}$} & \multicolumn{2}{|c|}{$\begin{array}{c}121-758 \mathrm{~A}-61 \mathrm{R}-6 \\
11-15 \mathrm{~cm}\end{array}$} & \multicolumn{4}{|c|}{$121-758 \mathrm{~A}-62 \mathrm{R}-1,82-87$} \\
\hline & 12 & 13 & 14 & 15 & 16 & 17 & 18 & 19 & 20 & 21 & 22 & 23 \\
\hline $\mathrm{SiO}_{2}$ & 55.66 & 64.84 & 46.99 & 52.58 & 48.45 & 54.19 & 48.45 & 47.56 & 47.68 & 46.51 & 52.06 & 45.71 \\
\hline $\mathrm{Al}_{2} \mathrm{O}_{3}$ & 25.52 & 18.13 & 33.2 & 28.98 & 31.96 & 27.96 & 31.35 & 32.69 & 32.64 & 33.74 & 29.25 & 33.73 \\
\hline $\mathrm{Fe}_{2} \mathrm{O}_{3}$ & 1.22 & 0.03 & 0.52 & 0.71 & 0.57 & 1.09 & 0.66 & 0.57 & 0.52 & 0.45 & 0.91 & 0.38 \\
\hline $\mathrm{CaO}$ & 9.54 & 0.04 & 17.82 & 13.06 & 16 & 11.81 & 15.87 & 17.27 & 17.25 & 18.34 & 13.33 & 18.38 \\
\hline $\mathrm{Na}_{2} \mathrm{O}$ & 5.79 & 0.1 & 1.58 & 4.23 & 2.28 & 4.77 & 2.76 & 1.79 & 1.78 & 1.37 & 4.2 & 1.21 \\
\hline $\mathrm{K}_{2} \mathrm{O}$ & 0.29 & 16.82 & 0.01 & 0.12 & 0.04 & 0.22 & 0.05 & 0.01 & 0.02 & 0.01 & 0.06 & 0 \\
\hline Total & 98.02 & 99.96 & 100.12 & 99.68 & 99.3 & 100.04 & 99.14 & 99.89 & 99.89 & 100.42 & 99.81 & 99.41 \\
\hline $\mathrm{O}$ & 32 & 32 & 32 & 32 & 32 & 32 & 32 & 32 & 32 & 32 & 32 & 32 \\
\hline Si & 10.246 & 12.019 & 8.647 & 9.594 & 8.94 & 9.827 & 8.973 & 8.756 & 8.775 & 8.545 & 9.506 & 8.487 \\
\hline Al & 5.537 & 3.961 & 7.201 & 6.233 & 6.951 & 5.976 & 6.844 & 7.094 & 7.08 & 7.307 & 6.295 & 7.382 \\
\hline $\mathrm{Fe}_{3}$ & 0.169 & 0.004 & 0.072 & 0.097 & 0.079 & 0.149 & 0.092 & 0.079 & 0.072 & 0.062 & 0.125 & 0.053 \\
\hline $\mathrm{Ca}$ & 1.882 & 0.008 & 3.514 & 2.553 & 3.163 & 2.295 & 3.149 & 3.407 & 3.402 & 3.611 & 2.608 & 3.657 \\
\hline $\mathrm{Na}$ & 2.067 & 0.036 & 0.564 & 1.497 & 0.816 & 1.677 & 0.991 & 0.639 & 0.635 & 0.488 & 1.487 & 0.436 \\
\hline K & 0.068 & 3.978 & 0.002 & 0.028 & 0.009 & 0.051 & 0.012 & 0.002 & 0.005 & 0.002 & 0.014 & 0 \\
\hline Sum & 19.969 & 20.006 & 20 & 20.002 & 19.958 & 19.975 & 20.061 & 19.977 & 19.969 & 20.015 & 20.035 & 20.015 \\
\hline An & 46.8 & 0.2 & 86.1 & 62.6 & 79.3 & 57 & 75.8 & 84.2 & 84.2 & 88 & 63.5 & 89.4 \\
\hline $\mathrm{Ab}$ & 51.5 & 0.9 & 13.8 & 36.7 & 20.5 & 41.7 & 23.9 & 15.8 & 15.7 & 11.9 & 36.2 & 10.6 \\
\hline Or & 1.7 & 98.9 & 0.1 & 0.7 & 0.2 & 1.3 & 0.3 & 0.1 & 0.1 & 0.1 & 0.3 & 0 \\
\hline
\end{tabular}

$0.512881\left(\varepsilon \mathrm{Nd}_{(\mathrm{t}=38 \text { m.y. }}\right)$ values of +3.91 and +4.74 , respectively $)$. ${ }^{87} \mathrm{Sr} /{ }^{86} \mathrm{Sr}$ ratios range from 0.70411 to 0.70417 ; no significant change occurred with acid-leaching. After strong acid-leaching, the samples from Site 756 define tight clusters without any discernible trend, in ${ }^{207} \mathrm{~Pb} /{ }^{204} \mathrm{~Pb}-{ }^{206 \mathrm{~Pb}} /{ }^{204} \mathrm{~Pb}$ and ${ }^{208} \mathrm{~Pb} /{ }^{204} \mathrm{~Pb}-$ ${ }^{206} \mathrm{~Pb} /{ }^{204} \mathrm{~Pb}$ space (Fig. 21). ${ }^{206} \mathrm{~Pb} /{ }^{204} \mathrm{~Pb}$ ranges from 18.67 to 18.77 , ratios which are significantly higher than in basalts from Kerguelen Island, and higher than previously published Ninetyeast Ridge data. ${ }^{207} \mathrm{~Pb} /{ }^{204} \mathrm{~Pb}$ ratios are lower than those measured in most other Ninetyeast Ridge basalts, with the exception of one sample from Site $758 .{ }^{208} \mathrm{~Pb} /{ }^{204} \mathrm{~Pb}$ ratios are high $(38.93$ to 38.94), and similar to values found in Site 757 and some Site 758 basalts. Note that in ${ }^{208} \mathrm{~Pb} /{ }^{204} \mathrm{~Pb}-{ }^{206} \mathrm{~Pb} /{ }^{204} \mathrm{~Pb}$ space, the basalts from Sites 756 overlap a group of high- $-206 \mathrm{~Pb} /{ }^{204} \mathrm{~Pb}$-ratio basalts from Heard Island (H2 on Fig. 21) (Barling and Goldstein, 1990), but not Kerguelen Island. In ${ }^{208} \mathrm{~Pb} /{ }^{204} \mathrm{~Pb}-{ }^{206} \mathrm{~Pb} /{ }^{204} \mathrm{~Pb}$ space, the 756 basalts also resemble St. Paul Island (Dupré and Allègre, 1983), but they have much lower ${ }^{207} \mathrm{~Pb} /{ }^{204} \mathrm{~Pb}$ ratios (St. Paul Island plots above the range on Fig. 21).

No systematic downhole variations in isotope ratios were detected, nor are there any correlations between elemental composition and isotope values.

\section{Site 757}

The basalts recovered at Site 757 are predominantly olivinetholeiites although some samples are slightly quartz-normative, and others are alkali basalts (Table 7). These variations may be due to secondary alteration. All samples fall on strong iron-enrichment curves (Fig. 9). The short basement section from Hole 757B comprises basalts compositionally and petrographically similar to the basalts from the upper part of Hole 757C (Unit 1), and we see no reason to consider them separately. Altogether, 18 lithological units were identified by shipboard studies. Of these, all but two minor units in Hole 757C, 15 and 16, were sampled and analyzed for the present study. We see no reason to modify the conclusions of the shipboard party, namely that two distinct chemical types occur in this basement section.

The uppermost units in Hole 757C, 1 through 14, comprise chemical type I (Fig. 22). These are mostly highly plagioclasephyric basalts, with up to $45 \%$ plagioclase phenocrysts, although considerable variation in plagioclase content does occur within individual flows (Table 7). Sample 121-757C-9R-6, 12-15 cm, for example, taken from the top of Unit 5, is virtually aphyric. This sample may more closely represents the composition of the parental magma prior to addition of plagioclase (see below). It has a moderate $\mathrm{Al}_{2} \mathrm{O}_{3}$ content $(16 \%)$, and is in several ways similar to the composition of the less-evolved basalts from Hole 756D. Thus, on Figures 9 and 10, it is seen to overlap the field of the Hole $756 \mathrm{D}$ basalts, although it has significantly lower abundances of incompatible elements (e.g., Ti, P, Zr, etc.: Fig. 14).

The chemical variations in chemical type $\mathrm{I}$ in Hole $757 \mathrm{C}$ are strongly influenced by the plagioclase phenocrysts. All of the samples, with the exception of the aphyric basalt, have high contents of $\mathrm{Al}_{2} \mathrm{O}_{3}$ (up to $24.2 \mathrm{wt} \%$ : Fig 23). Furthermore, the plagioclase-phyric samples all have low abundances of both incompatible (e.g., Ti, Zr, REE, Sc: Fig. 14) and compatible elements ( $\mathrm{Ni}$ and $\mathrm{Cr}$ : Figs. 11 and 12; and $\mathrm{V}$ ), strongly suggesting that the abundances have been diluted by addition of cumulus plagioclase. These data, and the low abundances of most trace elements (including $\mathrm{Ni}, \mathrm{Cr}$, and $\mathrm{V}$ ), are quantitatively consistent with addition of cumulus plagioclase to a basalt compositionally equivalent to Sample 121-757C-9R-6, 12-15 cm (Fig. 10). Note in particular the positive correlation between $\mathrm{Ni}$ and $\mathrm{Zr}$ (Fig. 14). $\mathrm{Zr}$ abundances decrease from $62 \mathrm{ppm}$ in the aphyric sample from Unit 5 , to $37 \mathrm{ppm}$ in the plagioclase-rich interior of this flow. Ni decreases from $88 \mathrm{ppm}$ to $60 \mathrm{ppm}$. These data indicate depletion factors of 0.60 and 0.68 , respectively, equating to addition of between $32 \%$ and $40 \%$ cumulus plagioclase. This is consistent with the observed modal abundances (Fig. 23). (Other units such as 6,7 , and 8 have lower contents of $\mathrm{Zr}$ and $\mathrm{Ni}$, indicating either addition of larger amounts of plagioclase (57\% required, but not observed) or a derivation from a more-depleted parental liquid.)

Both $\mathrm{Sr}$ and $\mathrm{Al}_{2} \mathrm{O}_{3}$ show strongly negative correlations with $\mathrm{Zr}$ in the chemical type I basalts (Figs. 7 and 16). Again, this is consistent with addition of cumulus plagioclase. Note, however, that the aphyric Sample 121-757C-9R-6, 12-15 cm, has the highest $\mathrm{Sr}$ content and does not fall at the low-Sr end of the $\mathrm{Zr}$-Sr trend as would be expected. This is probably a result of abundant carbonate- and zeolite-filled vesicles in this sample.

An unexpected observation is the increasing $\mathrm{Ti} / \mathrm{Zr}$ (Fig. 14), $\mathrm{P} / \mathrm{Zr}$ (Fig. 17), and P/Ti ratios of the plagioclase-rich (i.e., Zr-depleted) samples. Ideally, plagioclase feldspar has very low $\mathrm{P}$ and 
Table 4. Analyses of clinopyroxenes, Sites 757 and 758.

\begin{tabular}{|c|c|c|c|c|c|c|c|c|c|c|c|c|c|c|c|}
\hline \multirow{2}{*}{$\begin{array}{l}\text { Sample } \\
\text { Analysis number }{ }^{\mathrm{a}}\end{array}$} & \multicolumn{6}{|c|}{$121-757 \mathrm{C}-11 \mathrm{R}-2,128-132 \mathrm{~cm}$} & \multicolumn{6}{|c|}{$121-757 \mathrm{C}-12 \mathrm{R}-1,39-43 \mathrm{~cm}$} & \multicolumn{3}{|c|}{$\begin{array}{c}121-758 \mathrm{~A}-58 \mathrm{R}-3 \\
144-148 \mathrm{~cm}\end{array}$} \\
\hline & 1 & 2 & 3 & 4 & 5 & 6 & 7 & 8 & 9 & 10 & 11 & 12 & 13 & 14 & 15 \\
\hline $\mathrm{TiO}_{2}$ & 0.38 & 0.38 & 0.36 & 0.44 & 0.47 & 0.33 & 0.35 & 0.45 & 0.41 & 0.31 & 0.42 & 0.42 & 0.4 & 0.59 & 0.61 \\
\hline $\mathrm{Al}_{2} \mathrm{O}_{3}$ & 2.42 & 2.79 & 2.99 & 3.07 & 3.15 & 2.16 & 2.89 & 2.82 & 2.81 & 2.62 & 2.82 & 2.51 & 1.55 & 2.74 & 2.61 \\
\hline $\mathrm{Cr}_{2} \mathrm{O}_{3}$ & 0.55 & 0.57 & 0.59 & 0.47 & 0.55 & 0.34 & 0.44 & 0.47 & 0.57 & 0.52 & 0.62 & 0.48 & 0.06 & 0.04 & 0.01 \\
\hline $\mathrm{FeO}^{\circ}$ & 5.2 & 4.93 & 5.11 & 5.33 & 5.76 & 5.45 & 5.9 & 5.13 & 5.22 & 5.02 & 5.06 & 5.15 & 7.1 & 8.28 & 8.47 \\
\hline $\mathrm{MnO}$ & 0.18 & 0.18 & 0.11 & 0.09 & 0.16 & 0.14 & 0.14 & 0.13 & 0.16 & 0.08 & 0.1 & 0.15 & 0.17 & 0.25 & 0.23 \\
\hline $\mathrm{CaO}$ & 22.01 & 22.23 & 21.92 & 21.93 & 21.48 & 21.17 & 21.32 & 21.72 & 21.57 & 21.57 & 21.71 & 21.45 & 20.21 & 19.82 & 19.75 \\
\hline $\mathrm{Na}_{2} \mathrm{O}$ & 0.21 & 0.24 & 0.22 & 0.24 & 0.24 & 0.22 & 0.26 & 0.23 & 0.21 & 0.22 & 0.23 & 0.22 & 0.17 & 0.23 & 0.22 \\
\hline $\mathrm{K}_{2} \mathrm{O}$ & 0.01 & 0 & 0.01 & 0.01 & 0.01 & 0.01 & 0 & 0.01 & 0.01 & 0.01 & 0.01 & 0 & 0 & 0 & 0.01 \\
\hline Total & 100.89 & 100.62 & 100.63 & 100.45 & 100.64 & 100.78 & 100.72 & 100.81 & 100.62 & 100.62 & 100.66 & 100.44 & 100.54 & 99.91 & 100.39 \\
\hline o & 6 & 6 & 6 & 6 & 6 & 6 & 6 & 6 & 6 & 6 & 6 & 6 & 6 & 6 & 6 \\
\hline $\mathrm{Si}$ & 1.915 & 1.901 & 1.902 & 1.9 & 1.892 & 1.923 & 1.906 & 1.908 & 1.908 & 1.919 & 1.911 & 1.917 & 1.947 & 1.912 & 1.916 \\
\hline $\mathrm{Ti}$ & 0.01 & 0.01 & 0.01 & 0.012 & 0.013 & 0.009 & 0.01 & 0.012 & 0.011 & 0.008 & 0.012 & 0.012 & 0.011 & 0.016 & 0.017 \\
\hline Al & 0.104 & 0.12 & 0.129 & 0.132 & 0.136 & 0.093 & 0.124 & 0.121 & 0.121 & 0.112 & 0.121 & 0.108 & 0.067 & 0.12 & 0.113 \\
\hline $\mathrm{Cr}_{\mathrm{r}}$ & 0.016 & 0.016 & 0.017 & 0.014 & 0.016 & 0.01 & 0.013 & 0.014 & 0.016 & 0.015 & 0.018 & 0.014 & 0.002 & 0.001 & 0 \\
\hline $\mathrm{Mg}$ & 0.94 & 0.938 & 0.933 & 0.923 & 0.931 & 0.98 & 0.936 & 0.942 & 0.941 & 0.951 & 0.934 & 0.952 & 0.96 & 0.903 & 0.906 \\
\hline $\mathrm{Ca}$ & 0.858 & 0.87 & 0.857 & 0.859 & 0.842 & 0.825 & 0.834 & 0.846 & 0.843 & 0.841 & 0.847 & 0.838 & 0.792 & 0.787 & 0.78 \\
\hline $\mathrm{Na}$ & 0.015 & 0.017 & 0.016 & 0.017 & 0.017 & 0.016 & 0.018 & 0.016 & 0.015 & 0.016 & 0.016 & 0.016 & 0.012 & 0.017 & 0.016 \\
\hline Sum & 4.022 & 4.029 & 4.023 & 4.023 & 4.028 & 4.026 & 4.025 & 4.019 & 4.019 & 4.017 & 4.016 & 4.019 & 4.013 & 4.021 & 4.016 \\
\hline Wo & 43.9 & 44.4 & 44 & 44.2 & 43.2 & 41.9 & 42.8 & 43.5 & 43.4 & 43.2 & 43.8 & 43 & 40.2 & 40.4 & 40.1 \\
\hline En & 48.1 & 47.9 & 47.9 & 47.5 & 47.8 & 49.7 & 48 & 48.5 & 48.4 & 48.9 & 48.3 & 48.9 & 48.8 & 46.4 & 46.5 \\
\hline Fs & 8.1 & 7.7 & 8 & 8.4 & 9 & 8.4 & 9.2 & 8 & 8.2 & 7.9 & 8 & 8.1 & 11 & 13.2 & 13.4 \\
\hline Mg no. & 85.6 & 86.2 & 85.7 & 85 & 84.1 & 85.5 & 83.9 & 85.8 & 85.5 & 86.2 & 85.8 & 85.8 & 81.6 & 77.9 & 77.6 \\
\hline
\end{tabular}

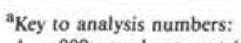

$1=800-\mu \mathrm{m}$ phenocryst (rim);

$2=800-\mu \mathrm{m}$ phenocryst (core);

$2=800-\mu \mathrm{m}$ phenocryst (core);
$3,4=1500-\mu \mathrm{m}$ phenocryst (core);

$3,4=1500-\mu \mathrm{m}$ phenocryst (core);
$5,6=2000-\mu \mathrm{m}$ phenocryst (core);

$5,6=2000-\mu \mathrm{m}$ phenocryst (core):
$7-12=$ pyroxene microphenocryst (core):

$\begin{aligned} 7-12 & =\text { pyroxene microphenocryst (core): } \\ 13-15 & =\text { individual pyroxene phenocryst cores }\end{aligned}$

$13-15=$ individual pyroxene phen
$16-18$ = groundmass pyroxenes;

19-24 = pyroxene phenocryst:

$25=1000-\mu \mathrm{m}$ phenocryst (rim);

$26=1000-\mu \mathrm{m}$ phenocryst (core);

$27=1500-\mu \mathrm{m}$ phenocryst (rim):

$28=1500-\mu \mathrm{m}$ phenocryst (core);

$29,30=3000-\mu$ phenocryst;

$31=300-\mu \mathrm{m}$ microphenocryst (core)

Ti content, so addition of plagioclase should not affect $\mathrm{P} / \mathrm{Ti}$ or $\mathrm{P} / \mathrm{Zr}$ ratios, but should dilute $\mathrm{P}$ and $\mathrm{Ti}$ abundances. This does not seem to have happened in this series.

The REE patterns for chemical type I (Fig. 15) are similar to those from Site 756, although the absolute abundances are lower. $\mathrm{La}_{n} / \mathrm{Yb}_{\mathrm{n}}$ ranges from 1.6 to 2.2 , slightly lower than the Site 756 basalts. Note that there are no significant Eu anomalies, which is surprising in view of the preceding statements about cumulus plagioclase, but it may indicate that the oxygen fugacity of the melt was too high to allow formation of $\mathrm{Eu}^{2+}$.

The spidergrams for chemical type I (Fig. 22) without mobile elements are similar in form to those from Site 756 basalts. $\mathrm{La} / \mathrm{Ta}$ (14 to 23) ratios are higher than those in the Site 756 basalts, but $\mathrm{Th} / \mathrm{Ta}(0.7$ to 1.6$)$ ratios are similar (Fig. 18$) . \mathrm{Zr} / \mathrm{Nb}$ ratios tend to be lower in the Site 757 basalts, but the range is greater ( 8 to 15 ), which suggests that the low abundances of $\mathrm{Nb}$ are giving imprecise ratios. (Note that the $\mathrm{Zr} / \mathrm{Ta}$ ratios of the basalts of Holes $757 \mathrm{C}$ and $756 \mathrm{D}$ are indistinguishable.) $\mathrm{Ti} / \mathrm{Zr}$ ratios range to higher values (up to 160 , which is higher than most in MORB) than in the Hole 756D samples.

Chemical type II (Fig. 22), recovered from the bottom of Hole $757 \mathrm{C}$ (Units 17 and 18), is distinct from the overlying units in that it is less plagioclase-rich and has lower $\mathrm{Al}_{2} \mathrm{O}_{3}$ contents. However, the chemical type II rocks are still aluminous, with $18.7 \%-19.5 \%$ $\mathrm{Al}_{2} \mathrm{O}_{3}$. The basalts are predominantly olivine-tholeiites (although one sample shows normative ne, and two are quartz-normative). By most criteria- $\mathrm{Ni}$ and $\mathrm{Cr}$ contents, $\mathrm{FeO} / \mathrm{MgO}$ ratio (1.1 to 1.3 ), and abundances of incompatible elements $\mathrm{Zr}, \mathrm{Hf}, \mathrm{REE}, \mathrm{Y}, \mathrm{Ba}, \mathrm{Ta}$, and $\mathrm{Nb}$ - these type II lavas are more evolved than chemical type
I and the basalts from Hole 756D. However, the samples have abundances of $\mathrm{TiO}_{2}, \mathrm{P}_{2} \mathrm{O}_{5}$, and $\mathrm{Sc}$ similar to those in the overlying units, resulting in low $\mathrm{Ti} / \mathrm{Zr}$ (29 to 38$), \mathrm{P} / \mathrm{Zr}$ (1.9 to 2.8 ), $\mathrm{Ti} / \mathrm{Nb}$ (507 to 660 ), and $\mathrm{Sc} / \mathrm{Zr}(0.14$ to 0.19$)$ ratios (Figs. 14 and 17 ). $\mathrm{Zr} / \mathrm{Nb}(16.5$ to 18.8$)$ and $\mathrm{Zr} / \mathrm{Ta}(221-275)$ ratios of these basalts are higher than those in chemical type I. Note, however, that Ti/V, $\mathrm{P} / \mathrm{Ti}$, and $\mathrm{Ti} / \mathrm{Sc}$ ratios are similar to those in chemical type $\mathrm{I}$ basalts.

Chemical type II basalts have REE profiles (Fig. 15) distinct from either type I basalts or, indeed, from any other basalts from Sites 756 and $758 . \mathrm{La}_{\mathrm{n}} / \mathrm{Yb}_{\mathrm{n}}$ ratios are higher (2.3 to 2.5$)$ and the profiles have small but significant negative Eu anomalies, indicating feldspar fractionation. The low content of heavy REE is consistent with the low Sc abundances of these rocks (Fig. 14) and indicates that either pyroxene or garnet removal has occurred.

We can detect no differences in $\mathrm{Pb}, \mathrm{Nd}$, or $\mathrm{Sr}$ isotope chemistry between chemical types I and II. Both groups have high ${ }^{206} \mathrm{~Pb} /{ }^{204} \mathrm{~Pb},{ }^{207} \mathrm{~Pb} /{ }^{204} \mathrm{~Pb}$, and ${ }^{208} \mathrm{~Pb} /{ }^{204} \mathrm{~Pb}$ ratios, and define moderately tight clusters in $\mathrm{Pb}$ isotope space (Fig. 21). ${ }^{207} \mathrm{~Pb} /{ }^{204} \mathrm{~Pb}$ ranges from 15.55 to 15.57 , which is significantly higher than those in the Site 756 basalts, but overlap the field of Site 253 basalts and some Site 758 samples. ${ }^{208} \mathrm{~Pb} /{ }^{204} \mathrm{~Pb}$ ratios are similar to the Site 756 basalts. The Site 757 basalts overlap the high ${ }^{206} \mathrm{~Pb} /{ }^{204} \mathrm{~Pb}$ ratio basalts (group $\mathrm{H} 2$ ) recovered from Heard Island (Barling and Goldstein, 1990).

The Site 757 basalts show a slightly greater range of ${ }^{87} \mathrm{Sr} /{ }^{86} \mathrm{Sr}$ ratios $(0.70445$ to 0.70482$)$ than those from the other Ninetyeast Ridge sites (Fig. 19). (Note that Sample 121-757C-9R-6, 12-15 $\mathrm{cm}$, which is an amygdalar, calcite- and zeolite-bearing basalt 
Table 4 (continued).

\begin{tabular}{|c|c|c|c|c|c|c|c|c|c|c|c|c|c|c|c|c|}
\hline \multirow{2}{*}{$\begin{array}{l}\text { Sample } \\
\text { Analysis number }{ }^{\mathrm{a}}\end{array}$} & \multicolumn{9}{|c|}{$121-758 \mathrm{~A}-67 \mathrm{R}-4,142-146 \mathrm{~cm}$} & \multicolumn{7}{|c|}{$121-758 \mathrm{~A}-69 \mathrm{R}-2,70-74 \mathrm{~cm}$} \\
\hline & 16 & 17 & 18 & 19 & 20 & 21 & 22 & 23 & 24 & 25 & 26 & 27 & 28 & 29 & 30 & 31 \\
\hline $\mathrm{SiO}_{2}$ & 53.19 & 50.9 & 52.76 & 52.2 & 52.65 & 51.22 & 52.13 & 52.72 & 50.71 & 52.69 & 51.91 & 52.13 & 52.78 & 51.9 & 50.73 & \\
\hline $\mathrm{TiO}_{2}^{2}$ & 0.42 & 0.35 & 0.94 & 0.46 & 0.43 & 0.41 & 0.75 & 0.48 & 0.33 & 0.76 & 0.44 & 0.62 & 0.44 & 0.41 & 0.58 & 0.95 \\
\hline $\mathrm{Al}_{2} \mathrm{O}_{3}$ & 1.77 & 1.98 & 4.18 & 2.46 & 2.98 & 2.55 & 3.58 & 2.55 & 2.46 & 4.09 & 2.22 & 2.62 & 2.48 & 2.09 & 2.73 & 2.87 \\
\hline $\mathrm{Cr}_{2} \mathrm{O}_{3}$ & 0.36 & 0.28 & 0.17 & 0.46 & 0.58 & 0.49 & 0.22 & 0.39 & 0.6 & 0.68 & 0.19 & 0.04 & 0.34 & 0.25 & 0.28 & 0.02 \\
\hline $\mathrm{FeO}$ & 6.89 & 6.93 & 7.21 & 5.75 & 5.81 & 5.68 & 6.59 & 5.98 & 5.25 & 6.1 & 6.36 & 7.09 & 6.16 & 6.34 & 6.64 & 10.86 \\
\hline $\mathrm{MnO}$ & 0.18 & 0.22 & 0.21 & 0.17 & 0.13 & 0.15 & 0.15 & 0.15 & 0.15 & 0.16 & 0.18 & 0.23 & 0.16 & 0.14 & 0.18 & 0.26 \\
\hline $\mathrm{MgO}$ & 19.16 & 19.13 & 16.31 & 17.56 & 17.16 & 17.41 & 16.51 & 17.09 & 17.58 & 16.47 & 17.38 & 16.41 & 17.01 & 17.5 & 17.14 & 15.1 \\
\hline $\mathrm{CaO}$ & 18.48 & 18.23 & 20.44 & 20.89 & 21.26 & 21.16 & 21.2 & 21.08 & 21.43 & 21.04 & 21.07 & 21.01 & 21.71 & 20.98 & 21.09 & 19.2 \\
\hline $\mathrm{Na}_{2} \mathrm{O}$ & 0.17 & 0.13 & 0.25 & 0.19 & 0.21 & 0.23 & 0.19 & 0.19 & 0.23 & 0.24 & 0.2 & 0.22 & 0.2 & 0.22 & 0.2 & 0.26 \\
\hline $\mathrm{K}_{2} \mathrm{O}$ & 0.01 & 0.01 & 0 & 0 & 0.01 & 0.01 & 0.01 & 0 & 0.01 & 0.01 & 0 & 0.01 & 0.01 & 0.01 & 0.01 & 0 \\
\hline Total & 100.73 & 100.45 & 100.61 & 100.7 & 100.77 & 100.74 & 100.42 & 100.04 & 100.76 & 100.26 & 100.73 & 100.16 & 100.64 & 100.72 & 100.75 & 100.25 \\
\hline o & 6 & 6 & 6 & 6 & 6 & 6 & 6 & 6 & 6 & 6 & 6 & 6 & 6 & 6 & 6 & 6 \\
\hline $\mathrm{Si}$ & 1.935 & 1.935 & 1.868 & 1.921 & 1.903 & 1.918 & 1.882 & 1.915 & 1.918 & 1.865 & 1.924 & 1.914 & 1.909 & 1.927 & 1.9 & 1.895 \\
\hline $\mathrm{Ti}$ & 0.011 & 0,01 & 0.026 & 0.013 & 0.012 & 0.011 & 0.02 & 0.013 & 0.009 & 0.021 & 0.012 & 0.017 & 0.012 & 0.011 & 0.016 & 0.027 \\
\hline Al & 0.076 & 0.085 & 0.181 & 0.106 & 0.128 & 0.109 & 0.155 & 0.11 & 0.105 & 0.177 & 0.096 & 0.114 & 0.107 & 0.09 & 0.118 & 0.126 \\
\hline $\mathrm{Cr}_{\mathrm{r}}$ & 0.01 & 0.008 & 0.005 & 0.013 & 0.017 & 0.014 & 0.006 & 0.011 & 0.017 & 0.02 & 0.005 & 0.001 & 0.01 & 0.007 & 0.008 & 0.001 \\
\hline $\mathrm{Fe}_{2}$ & 0.209 & 0.211 & 0.221 & 0.175 & 0.177 & 0.173 & 0.202 & 0.184 & 0.16 & 0.188 & 0.194 & 0.219 & 0.189 & 0.194 & 0.203 & 0.339 \\
\hline $\mathrm{Mn}$ & 0.006 & 0.007 & 0.007 & 0.005 & 0.004 & 0.005 & 0.005 & 0.005 & 0.005 & 0.005 & 0.006 & 0.007 & 0.005 & 0.004 & 0.006 & 0.008 \\
\hline $\mathrm{Mg}$ & 1.037 & 1.038 & 0.892 & 0.953 & 0.933 & 0.945 & 0.904 & 0.936 & 0.953 & 0.903 & 0.946 & 0.902 & 0.929 & 0.952 & 0.935 & 0.841 \\
\hline $\mathrm{Ca}$ & 0.719 & 0.711 & 0.804 & 0.815 & 0.831 & 0.826 & 0.835 & 0.83 & 0.835 & 0.829 & 0.824 & 0.83 & 0.852 & 0.821 & 0.827 & 0.768 \\
\hline $\mathrm{Na}$ & 0.012 & 0.009 & 0.018 & 0.013 & 0.015 & 0.016 & 0.014 & 0.014 & 0.016 & 0.017 & 0.014 & 0.016 & 0.014 & 0.016 & 0.014 & 0.019 \\
\hline Sum & 4.015 & 4.014 & 4,022 & 4.014 & 4.02 & 4.017 & 4.023 & 4.018 & 4.018 & 4.025 & 4.021 & 4.02 & 4.027 & 4.022 & 4.027 & 4.024 \\
\hline Wo & 36.6 & 36.3 & 41.9 & 41.9 & 42.8 & 42.5 & 43 & 42.6 & 42.9 & 43.2 & 42 & 42.5 & 43.2 & 41.7 & 42.1 & 39.4 \\
\hline En & 52.8 & 53 & 46.5 & 49 & 48.1 & 48.6 & 46.6 & 48 & 48.9 & 47 & 48.2 & 46.2 & 47.2 & 48.4 & 47.6 & 43.2 \\
\hline Fs & 10.6 & 10.8 & 11.5 & 9 & 9.1 & 8.9 & 10.4 & 9.4 & 8.2 & 9.8 & 9.9 & 11.2 & 9.6 & 9.9 & 10.3 & 17.4 \\
\hline Mg no. & 83.2 & 83.1 & 80.1 & 84.5 & 84 & 84.5 & 81.7 & 83.6 & 85.6 & 82.8 & 83 & 80.5 & 83.1 & 83.1 & 82.1 & 71.3 \\
\hline
\end{tabular}

with very high $\mathrm{Sr}$ contents, gives a ${ }^{87} \mathrm{Sr} /{ }^{86} \mathrm{Sr}$ ratio of 0.70600 even when acid-leached; this datum will not be considered further here although it is plotted on Fig. 19.)

Two ${ }^{143} \mathrm{Nd} /{ }^{144} \mathrm{Nd}$ ratios $\left(0.512737\right.$ and $0.512765 ; \varepsilon \mathrm{Nd}_{(\mathrm{t}}=58$ m.y.) of +2.3 and +2.9 ) from the two chemical units are virtually identical (Figs. 19 and 20 and Table 11).

\section{Site 758}

All of the analyzed samples from Hole 758A are olivine-tholeiites (Table 8, microfiche, back pocket). There is little variation in composition despite the thick section drilled, although below Unit 1 in Hole $758 \mathrm{C}$ there is a slight downhole decrease in the $\mathrm{FeO} / \mathrm{MgO}$ ratio and increase in the $\mathrm{Cr}$ and $\mathrm{Ni}$ contents. One sample from the plagioclase-phyric Unit 4 in Hole $758 \mathrm{C}$ has a much lower $\mathrm{FeO} / \mathrm{MgO}$ ratio, higher $\mathrm{Al}_{2} \mathrm{O}_{3}$ content, and higher $\mathrm{Ni}$ and $\mathrm{Cr}$ content than the other units recovered from this site.

The abundance of $\mathrm{MgO}$, which may have been affected by secondary alteration, varies from $7.6 \%$ to $11.0 \%$, and Ni from 52 to $111 \mathrm{ppm}$, indicating that these basalts are again moderately evolved; an iron-enrichment trend is again visible on the $\mathrm{FeO}$ vs.

Table 5. Glassy inclusions in feldspar phenocrysts, Site 757.

\begin{tabular}{lcccccc}
\hline Analysis number $^{\mathrm{a}}$ & 1 & 2 & 3 & 4 & 5 & 6 \\
\hline $\mathrm{SiO}_{2}$ & 48.8 & 50.5 & 49.1 & 48.4 & 47.8 & 48.5 \\
$\mathrm{TiO}_{2}$ & 1.40 & 1.15 & 1.50 & 0.94 & 0.59 & 1.25 \\
$\mathrm{Al}_{2} \mathrm{O}_{3}$ & 3.6 & 6.2 & 4.2 & 2.7 & 2.9 & 3.6 \\
$\mathrm{Cr}_{2} \mathrm{O}_{3}$ & 0.04 & 0.06 & 0.03 & 0.04 & 0.08 & 0.02 \\
$\mathrm{FeO}$ & 15.42 & 13.01 & 15.45 & 17.94 & 19.39 & 20.05 \\
$\mathrm{MnO}$ & 0.31 & 0.25 & 0.3 & 0.32 & 0.4 & 0.4 \\
$\mathrm{MgO}$ & 15.1 & 12.7 & 15.7 & 13.2 & 13.9 & 12.6 \\
$\mathrm{CaO}$ & 13.3 & 13.1 & 12.7 & 14.8 & 13.0 & 12.4 \\
$\mathrm{Na} 2$ & 1.1 & 5.3 & 1.1 & 1.7 & 1.2 & 2.3 \\
$\mathrm{~K}_{2} \mathrm{O}$ & 0.25 & 0.27 & 0.29 & 0.27 & 0.27 & 0.33 \\
$\mathrm{P}_{2} \mathrm{O}_{5}$ & 0.24 & 0.32 & 0.30 & 0.17 & 0.21 & 0.23 \\
$\mathrm{Total}$ & 99.58 & 102.73 & 100.58 & 100.41 & 99.67 & 101.54
\end{tabular}

Selected ratios

\begin{tabular}{lllllll}
$\mathrm{TiO}_{2} / \mathrm{P}_{2} \mathrm{O}_{5}$ & 0.17 & 0.28 & 0.20 & 0.18 & 0.36 & 0.18 \\
$\mathrm{FeO} / \mathrm{MgO}$ & 1.02 & 1.03 & 0.98 & 1.36 & 1.39 & 1.60 \\
\hline
\end{tabular}

Note: All analyses in wt $\%$.

${ }^{\mathrm{a}}$ Key to analysis numbers: $1-5=$ Sample $121-757 \mathrm{C}-9 \mathrm{R}-1,15-19 \mathrm{~cm} ; 6=$ Sample 121-757C-11R-2, 128-132 cm.
$\mathrm{FeO} / \mathrm{MgO}$ ratio diagram (Fig. 9). The plots of $\mathrm{Cr}$ or $\mathrm{Ni}$ vs. $\mathrm{FeO} / \mathrm{MgO}$ both define negative correlations indicative of olivine, pyroxene, and/or Cr-spinel control. Note that Unit 4 in Hole 758A has the highest $\mathrm{Cr}$ and $\mathrm{Ni}$ contents despite its high plagioclase content, suggesting that this sample represents a primitive magma. The incompatible element abundances (Figs. 15 and 24) are intermediate between those found at Holes 756D and 757C (type I). Again there is a tendency for less-incompatible/more-incompatible trace element ratios such as $\mathrm{Ti} / \mathrm{Zr}$ (Fig. 14) to decrease with increasing fractionation, although the trends are not as well defined as at the other sites. Sr, despite its tendency to be affected by secondary alteration, defines a tight trend when plotted against $\mathrm{Al}_{2} \mathrm{O}_{3}$ or $\mathrm{Zr}$; $\mathrm{Sr}$ remains approximately constant in this hole, unlike in Hole 757C.

The chondrite-normalized REE profiles are flat (Fig. 15), with $\mathrm{La}_{\mathrm{n}} / \mathrm{Yb}_{\mathrm{n}}$ ranging from 1 to 1.5 . Both $\mathrm{La} / \mathrm{Yb}$ and $\mathrm{Zr} / \mathrm{Y}$ (Fig. 17) increase with increasing $\mathrm{La}$ or $\mathrm{Zr}$, although the effect is not as marked as in the basalts from the other sites. Note that basalts from Holes 758 A and 757C (chemical type I) have identical $\mathrm{La} / \mathrm{Yb}$ and $\mathrm{Zr} / \mathrm{Y}$ ratios, lower than in Hole 756D basalts. Apart from Unit 4 in Hole 758A, which has a small positive Eu anomaly consistent with addition of plagioclase, no Eu anomalies are seen in the analyzed samples. Sc contents are similar to those found in the Hole $756 \mathrm{D}$ basalts ( $>40 \mathrm{ppm}$ ), which is consistent with the absence significant of heavy REE fractionation.

$\mathrm{Zr} / \mathrm{Nb}$ ratios (Fig. 17) vary from about 12 to 17 and thus overlap with the other sites, but we note that $\mathrm{Zr} / \mathrm{Ta}$ ratios tend to be higher than the other sites (up to nearly 400 ). This discrepancy between $\mathrm{Nb}$ and $\mathrm{Ta}$ may be due to the lack of precision in the low-Nb samples (down to $<3 \mathrm{ppm}$ ) recovered at this site. Other highly incompatible element ratios, such as $\mathrm{Th} / \mathrm{Ta}$ and $\mathrm{La} / \mathrm{Ta}$, are similar to those found at Site 757 , but there is a considerable spread of data: $\mathrm{La} / \mathrm{Ta}$ from 12 to 24 and $\mathrm{Th} / \mathrm{Ta}$ from 1.1. to 2.5 . The spidergrams (Fig. 24) reflect this similarity, showing similar distributions of the less mobile elements in basalts from Sites 757 (type I) and 758.

Acid-leached samples from this site give ${ }^{87} \mathrm{Sr} /{ }^{86} \mathrm{Sr}$ ratios of 0.70440 to 0.70473 , and ${ }^{143} \mathrm{Nd} /{ }^{144} \mathrm{Nd}$ values of 0.512765 to 0.512881 (Figs. 19 and 20 ), corresponding to $\varepsilon \mathrm{Nd}_{(\mathrm{t}=78 \mathrm{~m} . \mathrm{y} \text {.) }}$ values of +2.8 to +4.3 ). ${ }^{206} \mathrm{~Pb} /{ }^{204} \mathrm{~Pb}$ ratios range from 18.27 to 18.84 , which is the greatest diversity in any Ninetyeast Ridge site. More 
Table 10. Summary trace element and isotope ratios for NER basalts.

\begin{tabular}{|c|c|c|c|c|c|c|c|c|c|}
\hline $\begin{array}{l}\text { Site } \\
\text { Unit }\end{array}$ & $\begin{array}{l}756 \\
-\end{array}$ & $\begin{array}{c}757 \\
\text { Type I }\end{array}$ & $\begin{array}{c}757 \\
\text { Type II }\end{array}$ & $\begin{array}{l}758 \\
-\end{array}$ & 214 & 216 & $\begin{array}{c}253 \\
\text { Type I }\end{array}$ & $\begin{array}{c}253 \\
\text { Type II }\end{array}$ & $\frac{254}{-}$ \\
\hline $\mathrm{FeO} / \mathrm{MgO}$ & 1.53 & 0.99 & 1.23 & 1.02 & 3.62 & 1.55 & 0.85 & 0.68 & 1.57 \\
\hline $\mathrm{Rb} / \mathrm{Zr}$ & 0.147 & 0.415 & 0.090 & 0.044 & 0.111 & 0.097 & - & 0.264 & 0.048 \\
\hline $\mathrm{K} / \mathrm{Zr}$ & 29.1 & 232.1 & 74.7 & 13.0 & 35.2 & 39.2 & - & 132.3 & 43.4 \\
\hline $\mathrm{Ba} / \mathrm{Zr}$ & 0.336 & 0.676 & 0.537 & 0.351 & 0.830 & 0.706 & - & 2.209 & 0.461 \\
\hline $\mathrm{Ba} / \mathrm{Nb}$ & 4.45 & 7.84 & 9.23 & 5.21 & 11.22 & 8.37 & - & 27.32 & 6.20 \\
\hline $\mathrm{K} / \mathrm{Rb}$ & 362.2 & 590.5 & 864.5 & 1166.0 & 321.0 & 434.1 & - & 501.3 & 2278.9 \\
\hline $\mathrm{Rb} / \mathrm{Ba}$ & 0.450 & 0.601 & 0.166 & 0.126 & 0.134 & 0.136 & - & 0.119 & 0.111 \\
\hline $\mathrm{Th} / \mathrm{Ta}$ & 1.39 & 1.11 & 2.35 & 1.54 & 1.93 & 1.49 & 3.20 & 3.33 & 1.36 \\
\hline $\mathrm{La} / \mathrm{Ta}$ & 12.3 & 18.2 & 17.3 & 16.7 & 17.2 & 14.3 & 37.3 & 17.5 & 19.2 \\
\hline $\mathrm{Zr} / \mathrm{Nb}$ & 13.3 & 11.7 & 17.2 & 14.8 & 13.5 & 11.9 & - & 12.4 & 13.5 \\
\hline $\mathrm{Zr} / \mathrm{Ta}$ & 182.6 & 189.4 & 243.5 & 282.0 & 169.3 & 181.2 & - & 97.9 & 190.5 \\
\hline $\mathrm{La}_{\mathrm{n}} / \mathrm{Yb}_{\mathrm{n}}$ (NAA) & 2.30 & 4.28 & 2.81 & 1.37 & 4.16 & 3.44 & 2.44 & 0.74 & 2.28 \\
\hline $\mathrm{La}_{\mathrm{n}} / \mathrm{Yb} \mathrm{b}_{\mathrm{n}}$ (ICP) & 2.11 & 1.89 & 2.48 & 1.22 & - & - & - & - & - \\
\hline $\mathrm{Zr} / \mathrm{Y}$ & 4.13 & 2.96 & 5.28 & 2.99 & 5.35 & 4.96 & - & 0.80 & 3.54 \\
\hline $\mathrm{Zr} / \mathrm{Sc}$ & 3.07 & 1.51 & 5.85 & 1.45 & 19.23 & 4.31 & - & 0.36 & 3.02 \\
\hline $\mathrm{Ti} / \mathrm{Zr}$ & 103.1 & 127.6 & 34.6 & 120.2 & 22.9 & 89.9 & - & 191.3 & 103.9 \\
\hline $\mathrm{P} / \mathrm{Zr}$ & 6.7 & 9.4 & 2.3 & 7.3 & 7.8 & 6.1 & - & 9.7 & 7.3 \\
\hline $\mathrm{P} / \mathrm{Ti}$ & 0.07 & 0.07 & 0.07 & 0.06 & 0.34 & 0.07 & 0.46 & 0.05 & 0.07 \\
\hline $\mathrm{Ti} / \mathrm{Nb}$ & 1370 & 1473 & 593 & 1780 & 310 & 1066 & - & 2366 & 1406 \\
\hline $\mathrm{Cr} / \mathrm{V}$ & 0.73 & 1.03 & 0.54 & 0.58 & 0.01 & 0.26 & - & 2.45 & 1.17 \\
\hline $\mathrm{Cr} / \mathrm{Ni}$ & 3.16 & 3.05 & 2.51 & 2.72 & 0.12 & 2.03 & - & 2.28 & 1.85 \\
\hline $\mathrm{Ti} / \mathrm{V}$ & 40.8 & 28.9 & 29.3 & 24.2 & 215.5 & 39.3 & - & 17.7 & 48.4 \\
\hline $\mathrm{Nb} / \mathrm{Ta}$ & 14.2 & 17.4 & 14.5 & 19.6 & 12.7 & 14.9 & - & 7.9 & 16.1 \\
\hline $\mathrm{Zr} / \mathrm{Hf}$ & 41.5 & 34.7 & 44.0 & 36.8 & 40.3 & 43.6 & - & 19.6 & 35.3 \\
\hline${ }^{87} \mathrm{Sr} /{ }^{86} \mathrm{Sr}$ & 0.70411 & - & 0.70470 & 0.70473 & 0.70486 & - & - & - & 0.70465 \\
\hline${ }^{143} \mathrm{Nd} /{ }^{144} \mathrm{Nd}$ & 0.512881 & 0.512737 & 0.512765 & 0.512800 & 0.512833 & 0.512629 & 0.512873 & 0.512787 & 0.512759 \\
\hline$\epsilon$ Nd & 4.7 & 2.3 & 2.9 & 3.8 & 4.3 & 0.1 & 4.7 & 3.0 & 2.5 \\
\hline${ }^{206} \mathrm{~Pb} /{ }^{204} \mathrm{~Pb}$ & 18.705 & 18.815 & 18.749 & 18.756 & 18.344 & 18.106 & 18.709 & 18.768 & 18.054 \\
\hline${ }^{207} \mathrm{~Pb} /{ }^{204} \mathrm{~Pb}$ & 15.520 & 15.568 & 15.559 & 15.546 & 15.573 & 15.551 & 15.552 & 15.588 & 15.506 \\
\hline${ }^{208} \mathrm{~Pb} /{ }^{204} \mathrm{~Pb}$ & 38.915 & 38.903 & 39.010 & 38.737 & 38.736 & 38.746 & 38.549 & 38.659 & 38.587 \\
\hline $\mathrm{Age}^{\mathrm{a}}$ & $38 \mathrm{Ma}$ & $58 \mathrm{Ma}$ & $58 \mathrm{Ma}$ & $80 \mathrm{Ma}$ & $67 \mathrm{Ma}$ & $78 \mathrm{Ma}$ & $46 \mathrm{Ma}$ & $46 \mathrm{Ma}$ & $38 \mathrm{Ma}$ \\
\hline
\end{tabular}

Note: All analyses by X-ray fluorescence except where indicated (NAA = neutron activation analysis, and ICP = inductively coupled optical-emission plasma spectrometry); $\mathrm{La}_{\mathrm{n}} / \mathrm{Yb}_{\mathrm{n}}=$ chondrite-normalized $\mathrm{La} / \mathrm{Yb}$ ratio; dashes = not analyzed.

${ }^{a}$ Estimated age of basement from age of oldest overlying sediments used to calculate $\in \mathrm{Nd}$ values.

important, perhaps, is that both ${ }^{207} \mathrm{~Pb} /{ }^{204} \mathrm{~Pb}$ and ${ }^{208} \mathrm{~Pb} /{ }^{204} \mathrm{~Pb}$ ratios (Fig. 21) show strong, positive correlations with ${ }^{206} \mathrm{~Pb} /{ }^{204} \mathrm{~Pb}$ (except one sample which has a low ${ }^{207} \mathrm{~Pb} / 204 \mathrm{~Pb}$ value). We cannot account for this range of values at one site. The samples were treated in the same way as those from the other sites: leached in $6 \mathrm{M} \mathrm{HCl}$ acid in Teflon bombs for $12 \mathrm{hr}$ (pressure equivalent to 2 atmospheres) to remove alteration and possible contaminants introduced during crushing. One sample underwent repeated analysis without significant effect. Until further work is carried out, we accept that the array may not be primary. Note, however, that the Site 758 data are not outside the limit for other Ninetyeast Ridge sites (e.g., Site 254).

\section{Site 214}

Five new analyses of "oceanic andesite" (Hekinian, 1974a, 1974b) from this site are presented in Table 9 (microfiche, back pocket; ferrobasalt samples from the lower part of the hole were not analyzed during this study. All of the analyzed samples are evolved, with $\mathrm{MgO}$ less than $3 \%$, Ni less than $10 \mathrm{ppm}$, low abundances of $\mathrm{V}$, and $\mathrm{FeO} / \mathrm{MgO}>3$. Incompatible elements such as $\mathrm{P}, \mathrm{Zr}, \mathrm{Hf}, \mathrm{Nb}, \mathrm{Ta}, \mathrm{REE}$, and $\mathrm{Y}$ have the highest abundances in any of Ninetyeast Ridge samples (Fig. 24). Published REE data (fig. 22 of Thompson et al., 1974), together with one new set of data presented in Table 9 (microfiche, back pocket), show that the Site 214 andesites are light REE-enriched (Fig. 15), with $\mathrm{La}_{n} / \mathrm{Yb}_{n}$ ratios of 4.2 . Sc abundances (about $18 \mathrm{ppm}$ ) are much lower than in other Ninetyeast Ridge lavas (excluding the strongly porphyritic varieties), consistent with fractionation of garnet or clinopyroxene. Small negative Eu anomalies are present, indicative of feldspar fractionation.

New data show that the Site 214 andesites have low $\mathrm{Ti} / \mathrm{Zr}(21$ to 24$)$ and $\mathrm{Ti} / \mathrm{Nb}(288-327)$ ratios similar to those of the evolved basalts from the lower part of Hole 757C (Fig. 14). However, the Site 214 andesites retain high $\mathrm{P} / \mathrm{Zr}$ ratios ( 7 to 8 ), so the depletion of Ti may result from removal from the liquid of titanomagnetite, which is a phenocryst phase in this rocks. $\mathrm{Zr} / \mathrm{Nb}$ (13) ratios are similar to those found in Site 756, but $\mathrm{Th} / \mathrm{Ta}$ (1.93) and $\mathrm{La} / \mathrm{Ta}$ (17) ratios are generally higher than those in Site 756 basalts. The spidergram (Fig. 24) illustrates the strong enrichment of the more-incompatible elements in these andesites. Note the $\mathrm{Sr}$ depletion, consistent with extraction of plagioclase, and the depletion of $\mathrm{Ti}$, consistent with removal of titanomagnetite.

Ludden et al. (1980) have shown that the oceanic andesites recovered at this site can be related to the underlying basalts by fractionation of clinopyroxene, plagioclase, and titanomagnetite. Titanomagnetite fractionation may be responsible for removal of $\mathrm{Ta}$ from the melt, with the resulting increase in $\mathrm{La} / \mathrm{Ta}$ and $\mathrm{Th} / \mathrm{Ta}$ ratios.

Previous studies that have published isotope data for Site 214 lavas include Dupré and Allègre (1983) (Pb, Sr) and Mahoney et al. (1983) (Nd, Sr). The Site 214 andesites have a ${ }^{87} \mathrm{Sr} /{ }^{86} \mathrm{Sr}$ ratio of 0.70486 (cf. 0.70461: Dupré and Allègre, 1983), and a ${ }^{143} \mathrm{Nd} /{ }^{144} \mathrm{Nd}$ ratio of $0.512833\left(\varepsilon \mathrm{Nd}_{(\mathrm{t}}=67 \mathrm{m.y}\right.$.) of +4.3$)$; they closely resemble the basalts from Sites 756,757 , and 758 (Figs. 19 and 20). In $\mathrm{Pb}$ isotope space, however, the andesites (and basalts) of Site 214 have lower ${ }^{206} \mathrm{~Pb} /{ }^{204} \mathrm{~Pb}$ ratios than Site 756 and 757 basalts. Our new data give similar ${ }^{206} \mathrm{~Pb} /{ }^{204} \mathrm{~Pb}$ ratios to those determined by Dupré and Allègre, but our ${ }^{207} \mathrm{~Pb} /{ }^{204} \mathrm{~Pb}$ and ${ }^{208} \mathrm{~Pb} /{ }^{204} \mathrm{~Pb}$ ratios are lower. Overlap with the field for Kerguelen Island is apparent.

\section{Site 216}

Five new analyses of Site 216 basalts are included in Table 9 (microfiche, back pocket). These basalts have evolved composi- 
Table 11. Ninetyeast Ridge isotope data.

\begin{tabular}{|c|c|c|c|c|c|c|c|c|c|c|c|c|c|}
\hline $\begin{array}{c}\text { Sample } \\
\text { identifier }\end{array}$ & Hole & $\begin{array}{l}\text { Core, section, } \\
\text { interval }(\mathrm{cm})\end{array}$ & $\begin{array}{l}\text { Lithologic } \\
\text { unit }\end{array}$ & Sample & $\begin{array}{c}\text { Acid } \\
\text { leached? }\end{array}$ & ${ }^{206} \mathrm{~Pb} /{ }^{204} \mathrm{~Pb}$ & ${ }^{207} \mathrm{~Pb} /{ }^{204} \mathrm{~Pb}$ & ${ }^{208} \mathrm{~Pb} /{ }^{204} \mathrm{~Pb}$ & ${ }^{143} \mathrm{Nd} /{ }^{144} \mathrm{Nd}$ & Error & $\epsilon \mathrm{Nd}_{(\mathrm{t})}$ & ${ }^{87} \mathrm{Sr} /{ }^{86} \mathrm{Sr}$ & Error \\
\hline 11727 & $756 \mathrm{C}$ & $10 \mathrm{~N}-2,47-50$ & $756 \mathrm{C}-1$ & Powder & No & & & & 0.512881 & 6 & 4.74 & 0.70406 & 1 \\
\hline 11727 (AL) & $756 \mathrm{C}$ & $10 \mathrm{~N}-2,47-50$ & $756 \mathrm{C}-1$ & Powder & Yes & 18.667 & 15.516 & 38.926 & & & & 0.70411 & 1 \\
\hline 11729 & 756D & $4 R-1,43-46$ & $756 \mathrm{D}-1$ & Powder & No & & & & & & & 0.70417 & 1 \\
\hline 11729 (AL) & 756D & $4 R-1,43-46$ & $756 \mathrm{D}-1$ & Powder & Yes & 18.754 & 15.521 & 38.906 & & & & & \\
\hline 11735 (AL) & 756D & $6 \mathrm{R}-3,0-8$ & $756 \mathrm{D}-5$ & Powder & Yes & 18.633 & 15.524 & 38.883 & & & & & \\
\hline 11737 & 756D & $7 \mathrm{R}-2,134-137$ & $756 \mathrm{D}-5$ & Powder & No & & & & 0.512829 & 12 & 3.91 & 0.70417 & 1 \\
\hline 11737 (AL1) & $756 \mathrm{D}$ & 7R-2, 134-137 & $756 \mathrm{D}-5$ & Powder & Yes & 18.768 & 15.521 & 38.944 & & & & & \\
\hline 11752 & $757 \mathrm{C}$ & $9 \mathrm{R}-2,0-10$ & $757 \mathrm{C}-2$ & Powder & No & & & & & & & 0.70445 & 1 \\
\hline 11753 (AL) & $757 \mathrm{C}$ & $9 \mathrm{R}-2,88-92$ & $757 C-2$ & Powder & Yes & 18.662 & 15.561 & 38.876 & & & & & \\
\hline 11756 & $757 \mathrm{C}$ & $9 \mathrm{R}-6,12-15$ & $757 \mathrm{C}-5$ & Powder & No & & & & 0.512737 & 7 & 2.32 & 0.70567 & 1 \\
\hline 11756 (AL) & $757 \mathrm{C}$ & $9 R-6,12-15$ & $757 \mathrm{C}-5$ & Powder & Yes & & & & & & & 0.70600 & 1 \\
\hline 11765 & $757 \mathrm{C}$ & 10R-3, $115-115$ & $757 C-9$ & Powder & No & & & & & & & 0.70546 & 1 \\
\hline 11765 (AL) & $757 \mathrm{C}$ & $10 \mathrm{R}-3,115-115$ & $757 C-9$ & Powder & Yes & 18.968 & 15.574 & 38.930 & & & & & \\
\hline 11773 & $757 C$ & $12 \mathrm{R}-1,104-110$ & $757 \mathrm{C}-18$ & Powder & No & & & & 0.512765 & 4 & 2.86 & 0.70444 & 1 \\
\hline 11773 (AL) & $757 \mathrm{C}$ & $12 \mathrm{R}-1,104-110$ & $757 \mathrm{C}-18$ & Powder & Yes & 18.820 & 15.565 & 39.029 & & & & 0.70470 & 1 \\
\hline 11775 & $757 \mathrm{C}$ & $12 \mathrm{R}-3,32-37$ & $757 C-18$ & Powder & No & & & & & & & 0.70485 & 1 \\
\hline 11775 (AL) & $757 \mathrm{C}$ & $12 \mathrm{R}-3,32-37$ & $757 C-18$ & Powder & Yes & 18.679 & 15.554 & 38.990 & & & & 0.70482 & 1 \\
\hline 11780 & $758 \mathrm{~A}$ & $55 \mathrm{R}-5,92-96$ & $758 \mathrm{~A}-1$ & Powder & No & & & & 0.512881 & 7 & 2.81 & 0.70474 & 1 \\
\hline 11780 (AL) & $758 \mathrm{~A}$ & $55 \mathrm{R}-5,92-96$ & $758 \mathrm{~A}-1$ & Powder & Yes & 18.778 & 15.521 & 38.879 & & & & & \\
\hline 11788 & $758 \mathrm{~A}$ & $58 \mathrm{R}-5,45-49$ & $758 \mathrm{~A}-2$ & Powder & No & & & & 0.512831 & 5 & 4.11 & 0.70496 & 1 \\
\hline 11788 (AL) & $758 \mathrm{~A}$ & $58 \mathrm{R}-5,45-49$ & $758 \mathrm{~A}-2$ & Powder & Yes & 18.269 & 15.528 & 38.484 & & & & & \\
\hline 11797 & $758 \mathrm{~A}$ & $60 \mathrm{R}-7,17-21$ & $758 \mathrm{~A}-3$ & Powder & No & & & & 0.512800 & 5 & 3.43 & 0.70472 & 1 \\
\hline 11797 (AL) & $758 \mathrm{~A}$ & $60 \mathrm{R}-7,17-21$ & $758 \mathrm{~A}-3$ & Powder & Yes & 18.842 & 15.589 & 38.882 & & & & 0.70473 & 1 \\
\hline 11804 & $758 \mathrm{~A}$ & $63 \mathrm{R}-1,54-57$ & $758 \mathrm{~A}-7$ & Powder & No & & & & 0.512765 & 6 & 2.50 & 0.70501 & 1 \\
\hline 11804 (AL) & $758 \mathrm{~A}$ & $63 R-1,54-57$ & $758 \mathrm{~A}-7$ & Powder & & & & & & & & 0.70458 & 1 \\
\hline 11804 (leachate) & & & & & & & & & & & & 0.70553 & 1 \\
\hline 11830 & $758 \mathrm{~A}$ & $73 R-1,133-135$ & 758A-27 & Powder & No & & & & 0.512852 & 4 & 4.27 & 0.70463 & 1 \\
\hline $11830(\mathrm{AL})$ & $758 \mathrm{~A}$ & $73 \mathrm{R}-1,133-135$ & $758 \mathrm{~A}-27$ & Powder & Yes & 18.478 & 15.547 & 38.705 & & & & 0.70440 & 1 \\
\hline 11803 (leachate) & & & & & & & & & & & & 0.70508 & 1 \\
\hline 10670 (AL) & 214 & $48-1,55-57$ & & Chips & Yes & 18.346 & 15.579 & 38.750 & & & & 0.70486 & 1 \\
\hline 10674 (AL) & 214 & $51-1,122-125$ & & Chips & Yes & 18.343 & 15.566 & 38.722 & 0.512833 & 3 & 4.34 & & \\
\hline $10662(\mathrm{AL})$ & 216 & $37-1,23-25$ & & Chips & Yes & 18.080 & 15.561 & 38.805 & 0.512629 & 36 & 0.12 & & \\
\hline \multirow[t]{2}{*}{10664 (AL) } & 216 & $38-1,53-55$ & & Chips & Yes & 18.132 & 15.541 & 38.686 & & & & & \\
\hline & 253 & $24-1,84-85$ & & Chips & Yes & 18.709 & 15.552 & 38.549 & 0.512873 & 3 & 4.67 & & \\
\hline 11404 (AL) & 253 & $58-\mathrm{CC}$ & & Chips & Yes & 18.768 & 15.588 & 38.659 & 0.512787 & 20 & 3.00 & & \\
\hline 10666 (AL) & 254 & $31-1,100-103$ & & Chips & Yes & 18.030 & 15.501 & 38.550 & 0.512759 & 6 & 2.54 & 0.70465 & 1 \\
\hline 10669 (AL) & 254 & $38-1,117-119$ & & Chips & Yes & 18.079 & 15.511 & 38.623 & 0.512785 & 3 & 2.94 & & \\
\hline
\end{tabular}

Notes: $\mathrm{AL}=$ acid leached; $\epsilon \mathrm{Nd}$ age corrections as follows: Site 756 and $254=38 \mathrm{Ma}$, Site $253=46 \mathrm{Ma}$, Site $757=58 \mathrm{Ma}$, Site $214=67 \mathrm{Ma}$, Site $216=78 \mathrm{Ma}$, and Site $758=80 \mathrm{Ma}$ 


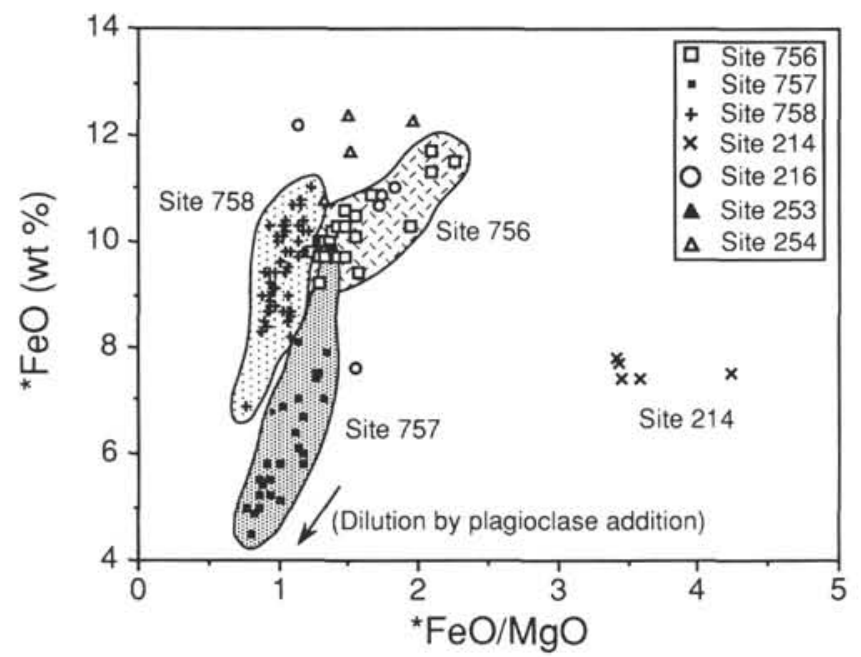

Figure 9. Abundances of $* \mathrm{FeO}$ vs. ${ }^{*} \mathrm{FeO} / \mathrm{MgO}$ in basalts from Sites 756,757 , and 758 , and DSDP Sites $214,216,253$, and $254 .(* \mathrm{FeO}=\mathrm{FeO}$ calculated assuming an $\mathrm{Fe}_{2} \mathrm{O}_{3} / \mathrm{FeO}$ ratio of 0.15 .)

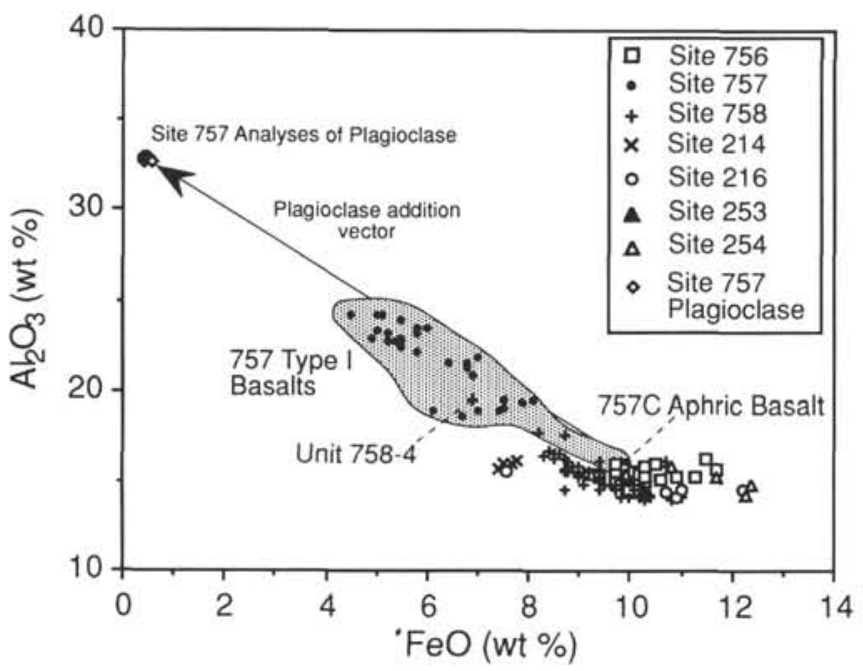

Figure 10. Abundances of $\mathrm{Al}_{2} \mathrm{O}_{3}$ vs. $* \mathrm{FeO}$ in basalts from Sites 756,757 , and 758 , and DSDP Sites $214,216,253$, and 254. The high $\mathrm{Al}_{2} \mathrm{O}_{3}$ content of plagioclase-phyric samples from Site 757 is very apparent. The "757C aphyric basalt" is Sample 121-757C-9R-6, 12-15 cm (see text). Representative analyses of plagioclase are taken from Table $3 .(* \mathrm{FeO}=\mathrm{FeO}$ calculated assuming an $\mathrm{Fe}_{2} \mathrm{O}_{3} / \mathrm{FeO}$ ratio of 0.15 .)

tions: samples from the lower part of the succession are ferrobasalts, with total iron ranging from $13.5 \%$ to $15.4 \% \mathrm{Fe}_{2} \mathrm{O}_{3}$. $\mathrm{FeO} / \mathrm{MgO}$ ranges from 1.13 to 1.82 , and $\mathrm{Ni}$ from 40 to $52 \mathrm{ppm}$. Sample $216-36-4,14-16 \mathrm{~cm}$, has a very high $\mathrm{CaO}$ content which is probably due to secondary alteration.

$\mathrm{Ti}, \mathrm{P}, \mathrm{Zr}$, and other incompatible element abundances are high, which is consistent with the fractionated nature of these ferrobasalts. Interelement ratios are as follows: $\mathrm{Ti} / \mathrm{Zr}=78$ to $90, \mathrm{P} / \mathrm{Zr}=$ 5 to 7 (Fig. 17), $\mathrm{Zr} / \mathrm{Nb}=11$ to $12, \mathrm{La} / \mathrm{Ta}=14$, and $\mathrm{Th} / \mathrm{Ta}=1.5$. These values overlap with other basalts (e.g., Site 756) from Ninetyeast Ridge.

The Site 216 basalts are characterized by light REE enrichment $\left(\mathrm{La} / \mathrm{Yb} \mathrm{b}_{\mathrm{n}}\right.$ of about 3 ) with a negative Eu anomaly in one newly

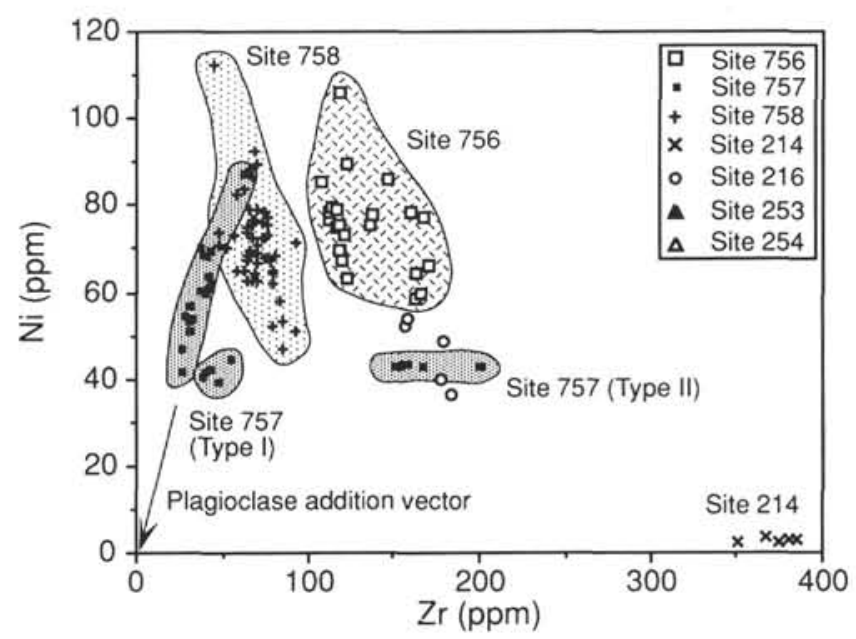

Figure 11. Abundances of $\mathrm{Ni}$ vs. $\mathrm{Zr}$ in basalts from Sites 756, 757, and 758, and DSDP Sites 214, 216, 253, and 254.

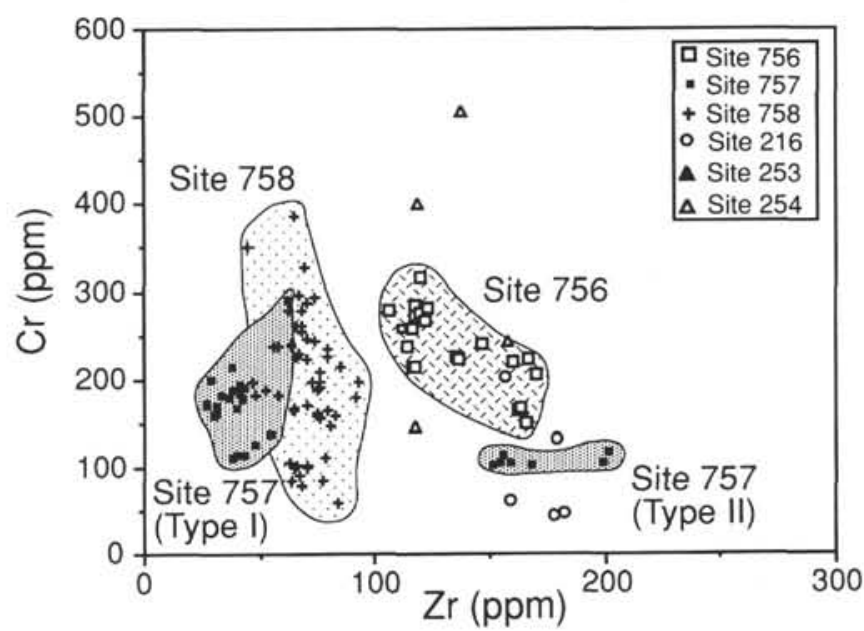

Figure 12. Abundances of $\mathrm{Cr}$ vs. $\mathrm{Zr}$ in basalts from Sites 756, 757, and 758, and DSDP Sites 216, 253, and 254.

analyzed sample (Sample 216-38-1, 53-55 cm). Sc abundances (42 ppm) are similar to MORB and Site 756 and 758 basalts. The basalts from Site 216 are incompatible element-enriched in relation to basalts from Site 214 (Ludden et al., 1980).

Site 216 basalts again define their own field in $\mathrm{Pb}$ isotope space; like the basalts from Site 214 , they have high ${ }^{207} \mathrm{~Pb} /{ }^{204} \mathrm{~Pb}$ and ${ }^{208} \mathrm{~Pb} /{ }^{204} \mathrm{~Pb}$ ratios, but the ${ }^{206} \mathrm{~Pb} /{ }^{204} \mathrm{~Pb}$ ratios are lower. Our new data are similar (we obtain slightly higher ${ }^{206} \mathrm{~Pb} /{ }^{204} \mathrm{~Pb}$ ratios) to those determined by Dupré and Allègre (1983) and confirm the similarities to basalts from Kerguelen Island. One ${ }^{143} \mathrm{Nd} /{ }^{144} \mathrm{Nd}$ analysis gives a ratio of 0.512629 , which corresponds to an $\varepsilon \mathrm{Nd}_{(\mathrm{t}}=78 \mathrm{~m}$.y.) value of +0.12 (the lowest epsilon value determined for Ninetyeast Ridge samples).

\section{Site $\mathbf{2 5 3}$}

We have analyzed only two samples from this site. An olivinerich basaltic unit at the base of the hole (Sample 253-58-CC) has high $\mathrm{MgO}$ and $\mathrm{Ni}$ contents and low contents of incompatible elements, consistent with addition of cumulus olivine; however, 


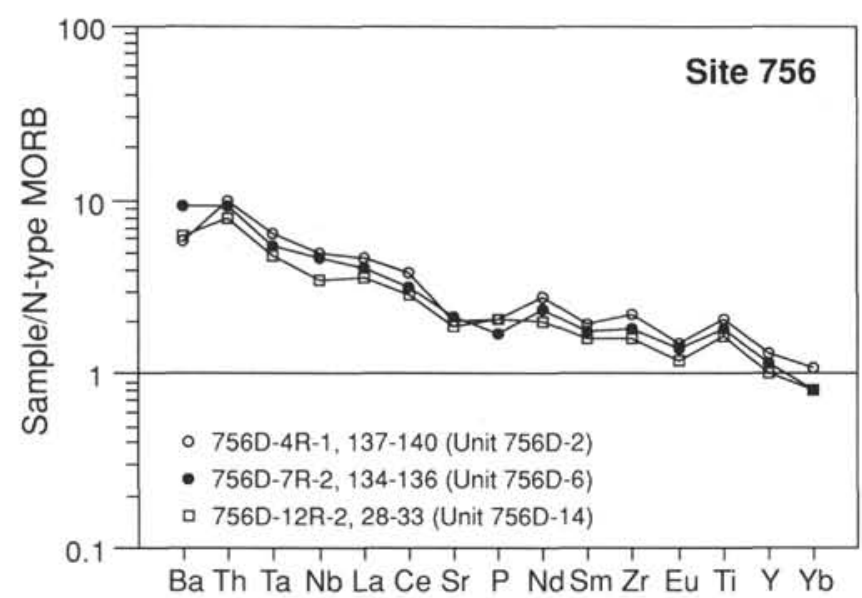

Figure 13. Abundances of incompatible elements in representative basalts from Site 756 normalized to N-type MORB. Normalizing values from Sun and McDonough (1989). K and Rb have not been included because of their apparent mobility during secondary alteration.

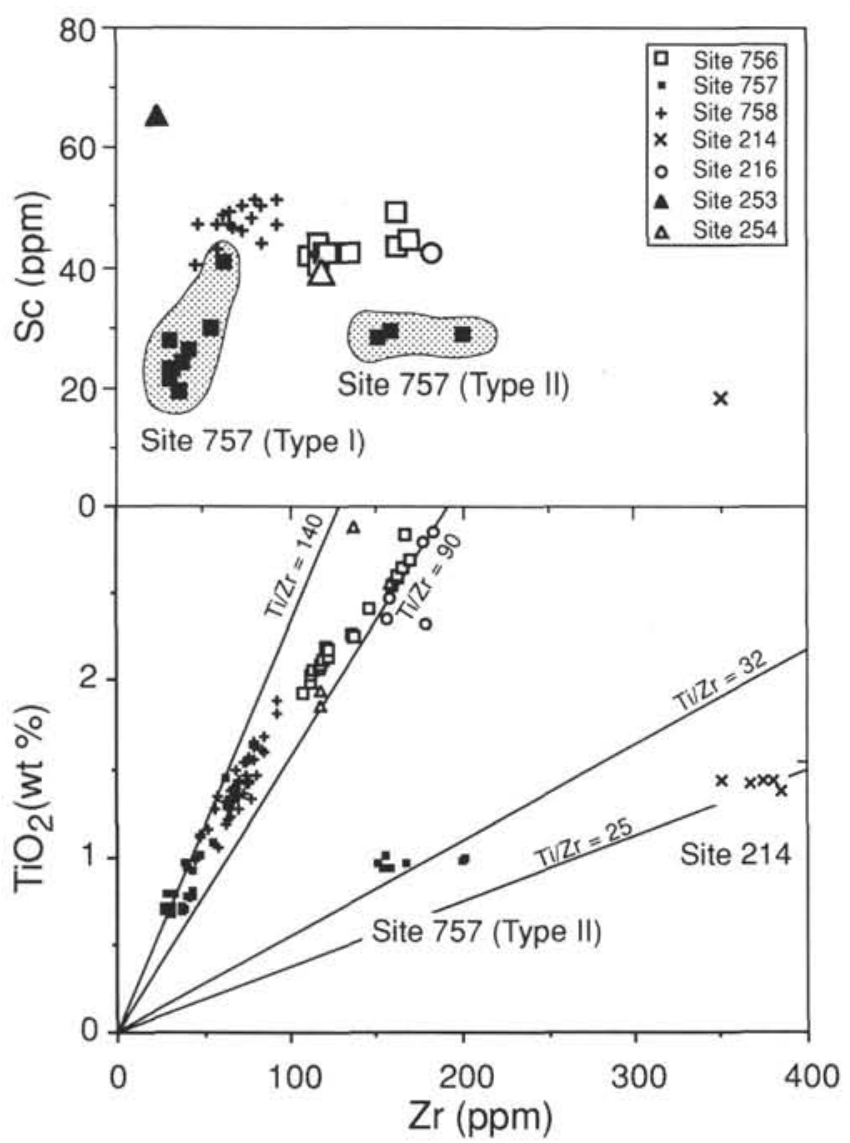

Figure 14. Abundances of $\mathrm{Zr}$ vs. $\mathrm{TiO}_{2}$ and $\mathrm{Sc}$ in basalts from Sites 756, 757, and 758 , and DSDP Sites $214,216,253$, and 254.

the $\mathrm{Sc}$ values are very high ( $65 \mathrm{ppm})$, suggesting that the primitive composition of this basalt is not entirely due to olivine accumulation (this would have diluted the $\mathrm{Sc}$ values). The $\mathrm{La}_{\mathrm{n}} / \mathrm{Yb}_{\mathrm{n}}$ ratio in this sample is low $(0.7)$ and the $\mathrm{Ti} / \mathrm{Zr}$ ratio is very high (191).
$\mathrm{Zr} / \mathrm{Nb}$ ratios (12) are within the range of other Ninetyeast Ridge basalts.

The other analyzed sample is an intraformational basalt flow (Sample 253-24-1) which is aluminous and $\mathrm{SiO}_{2}$-rich. It is incompatible-element- and light $\mathrm{REE}-$ enriched $\left(\mathrm{La}_{\mathrm{n}} / \mathrm{Yb}_{\mathrm{n}}=2.4\right)$. Both samples have high $\mathrm{Th} / \mathrm{Ta}$ (3.2 and 3.3) and $\mathrm{La} / \mathrm{Ta}$ (17.5 and 37) ratios. Note that Sample 253-58-CC has a $\mathrm{Zr} / \mathrm{Hf}$ ratio of 19.6 , which is much lower than the anticipated chondritic and terrestrial ratio of about 40 . This suggests to us that the Hf value may in error. Although the olivine-rich unit at this site has been compared with light REE-depleted MORB (Frey and Sung, 1974; Frey et al., 1977; Ludden et al., 1980), the low $\mathrm{Zr} / \mathrm{Nb}$ ratio and high $\mathrm{Th} / \mathrm{Ta}$ ratio of this unit is not typical of $\mathrm{N}$-type MORB.

The two units have indistinguishable isotopic characteristics. These basalts have high ${ }^{206} \mathrm{~Pb} /{ }^{204} \mathrm{~Pb}$ ratios. In this respect they resemble the basalts of Sites 756 and 757. In $\mathrm{Pb}$ isotope space, the samples overlap the field of Site 757 basalts and part of the field of Site 758 , but they have low ${ }^{208} \mathrm{~Pb} /{ }^{204} \mathrm{~Pb}$ values compared with most other Ninetyeast Ridge basalts. The two Nd isotope measurements are similar, giving $\varepsilon \mathrm{Nd}_{(\mathrm{t}}=46$ m.y.) values of +3.0 and +4.7 .

\section{Site 254}

We have analyzed four samples from Site 254 , the youngest site drilled on Ninetyeast Ridge. All of the basalts are low-Ca ferrobasalts, with moderate contents of incompatible elements (e.g., $\mathrm{TiO}_{2}$ ranges from $1.86 \%$ to $2.89 \%$; $\mathrm{Zr}$ from 118 to $158 \mathrm{ppm}$ ). Despite their apparent fractionated state, however, the basalts have high $\mathrm{Ni}$ contents ( 86 to $249 \mathrm{ppm}$ ), consistent with the frequent occurrence of olivine phenocrysts; furthermore, there is a positive correlation between $\mathrm{Fe}$ and $\mathrm{Ni}$ contents. Sc contents are high (39 ppm).

Published and new REE data show the light REE-enriched character of the Site 254 basalts. Indeed, the interelement ratios are typical of Ninetyeast Ridge basalts $\left(\mathrm{La}_{\mathrm{n}} / \mathrm{Yb}_{\mathrm{n}}=2.3, \mathrm{Zr} / \mathrm{Nb}=\right.$ 12 to $15, \mathrm{Th} / \mathrm{Ta}=1.36$, and $\mathrm{Ti} / \mathrm{Zr}=94$ to 125$)$. The $\mathrm{La} / \mathrm{Ta}$ ratio (19) is higher than that for most Ninetyeast Ridge basalts, and more typical of the values found in N-type MORB.

The Site 254 basalts have the lowest ${ }^{206} \mathrm{~Pb} /{ }^{204} \mathrm{~Pb}$ ratios determined during the present study - down to 18.03 - of the measured Ninetyeast Ridge samples. $\varepsilon \mathrm{Nd}_{(t}=38$ m.y.) values for the two analyzed samples are +2.5 and +2.9 , and ${ }^{87} \mathrm{Sr} /{ }^{86} \mathrm{Sr}$ ratio for one sample is 0.70465 (Table 11).

\section{DISCUSSION}

\section{Intrasite Variations}

We have not at this stage attempted quantitative petrologic modeling of the compositional variations that occur between the different units at Ninetyeast Ridge sites. At Site 756, the data are consistent with olivine and minor plagioclase fractionation and removal of a small amount of pyroxene to account for the decreasing $\mathrm{Sc} / \mathrm{Zr}$ ratios. The data are poorly constrained and an exhaustive evaluation may not be possible.

The Site 757 data are clearly more interesting. There is strong evidence for plagioclase accumulation in many of the chemical type I lavas from Hole 757C; dilution of incompatible and compatible elements such as $\mathrm{Ni}, \mathrm{Cr}$, and $\mathrm{V}$ cannot be explained by other models. There are several problems with this model, however. For example, the increasing $\mathrm{P} / \mathrm{Zr}$ ratio in the more aluminous samples appears to require addition of apatite (perhaps as crystallites in inclusions within the plagioclase phenocrysts). Further work on this aspect of the lavas is in progress. The absence of Eu anomalies in the strongly plagioclase-phyric lavas is also unexpected, particularly in view of the high $\mathrm{Sr}$ contents. However, the 

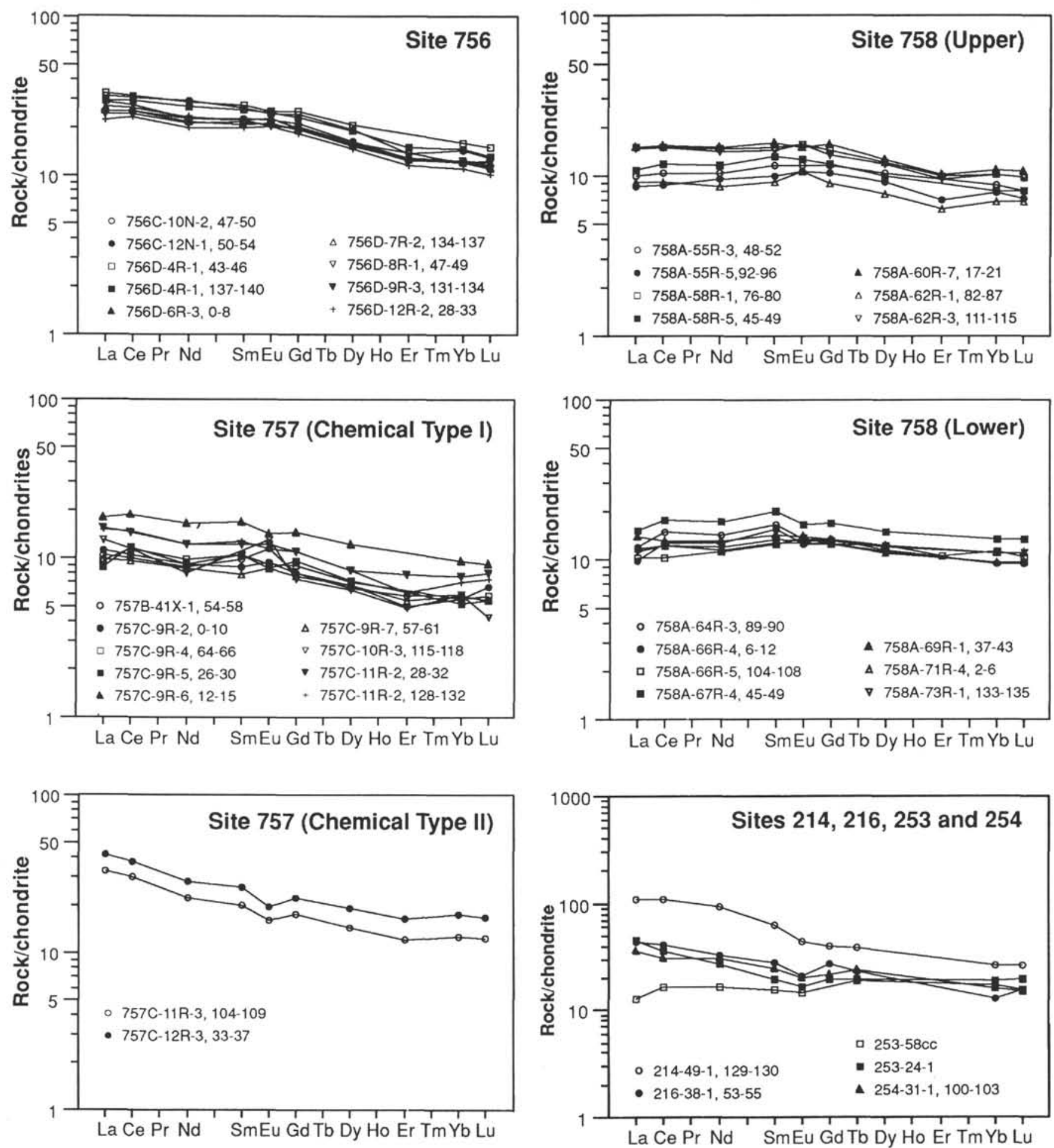

Figure 15. Chondrite-normalized rare earth element abundances in basalts from Sites 756, 757 (chemical Types I and II), and 758, and DSDP Sites 214, 216, 253, and 254. Normalizing values from Nakamura (1974). All REE determined by ICP, except for the DSDP samples, which were analyzed by NAA. Site 758 data are separated for clarity; no downhole chemical variation is implied.

low partition coefficient for Eu in calcic plagioclase (most of the phenocrysts are bytownitic in composition) probably ensures that plagioclase accumulation has a minimal effect on the REE abundances. It is also possible that the magma had a high oxygen fugacity (see below), which would maintain a high $\mathrm{Eu}^{3+} / \mathrm{Eu}^{2+}$ ratio, again maintaining low partition coefficients for Eu in plagioclase.

The chemical type II in Hole 757C lavas are distinct from the overlying units. The low $\mathrm{Ti} / \mathrm{Zr}, \mathrm{V} / \mathrm{Zr}$, and $\mathrm{Sc} / \mathrm{Zr}$ ratios indicate fractionation of pyroxene and/or titanomagnetite. In several re- 


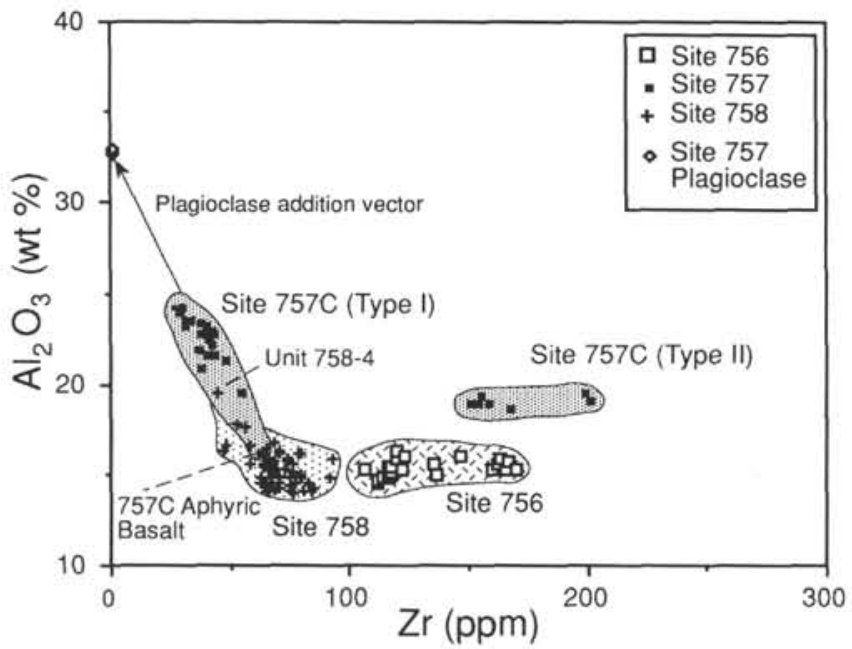

Figure 16. Abundances of $\mathrm{Al}_{2} \mathrm{O}_{3}$ vs. $\mathrm{Zr}$ in basalts from Sites 756, 757, and 758 . Representative analyses of plagioclase are taken from Table 3.

spects these lavas are intermediate in composition between more normal Ninetyeast Ridge lavas (e.g., least evolved lavas from Sites 756 and 758) and the oceanic andesites recovered at Site 214 , where titanomagnetite fractionation has been proposed (Ludden at al., 1980). However, the Site $757 \mathrm{C}$ lavas are relatively unevolved (although they have lost plagioclase and olivine), certainly not andesitic, and it is initially difficult to see how the titanomagnetite stability field could be reached. Furthermore, the constant $\mathrm{Ti} / \mathrm{P}$ ratios in these lavas show that a phase is removing $\mathrm{P}$ - probably apatite, which again normally does not crystallize until the magma is more evolved. There are at least three possible explanations for these observations. First, titanomagnetite formation may be enhanced by a high oxygen fugacity in the magma. This is consistent with the absence a positive Eu anomaly in the overlying magmas and with the vesicular nature of these (and other) Ninetyeast Ridge lavas. However, a high oxygen fugacity does not account for the removal of phosphorus. Second, these lavas may represent mixed magmas, formed by mixing of basaltic and "andesitic" (which had lost titanomagnetite during an earlier fractionation episode) magmas in a subvolcanic chamber. The petrographic data do not support this suggestion, in that mixed populations of phenocrysts are absent, although the similarity in composition of the pyroxene phenocrysts from types I and II in Hole $757 \mathrm{C}$ does lend support to this idea. Third, the dominant fractionating phase is pyroxene rather than titanomagnetite. This is consistent with removal of $\mathrm{Ti}, \mathrm{P}, \mathrm{Sc}$, and $\mathrm{V}$, and accounts for the increased $\mathrm{La} / \mathrm{Yb}$ ratios in the type II basalts. Quantitative modeling is in progress.

There is no discernible difference between the isotopic ratios of the two chemical types recovered at Site 757 , indicating that they came from the same mantle source(s). Note that the type II lavas have high $\mathrm{Th} / \mathrm{Ta}$ and $\mathrm{Zr} / \mathrm{Nb}$ ratios, perhaps because titanomagnetite fractionation removed $\mathrm{Ta}$ and $\mathrm{Nb}$ from the liquid (cf. Wood 1978).

The Site 758 lavas can be related by the removal of olivine and plagioclase. There is no obvious pyroxene removal even though small pyroxene phenocrysts are present in several units. Plagioclase accumulation has clearly occurred in Unit 4 in Hole $758 \mathrm{~A}$, and this has resulted in small positive Eu anomalies. The Site 758 lavas are weakly vesicular and were probably erupted in deep

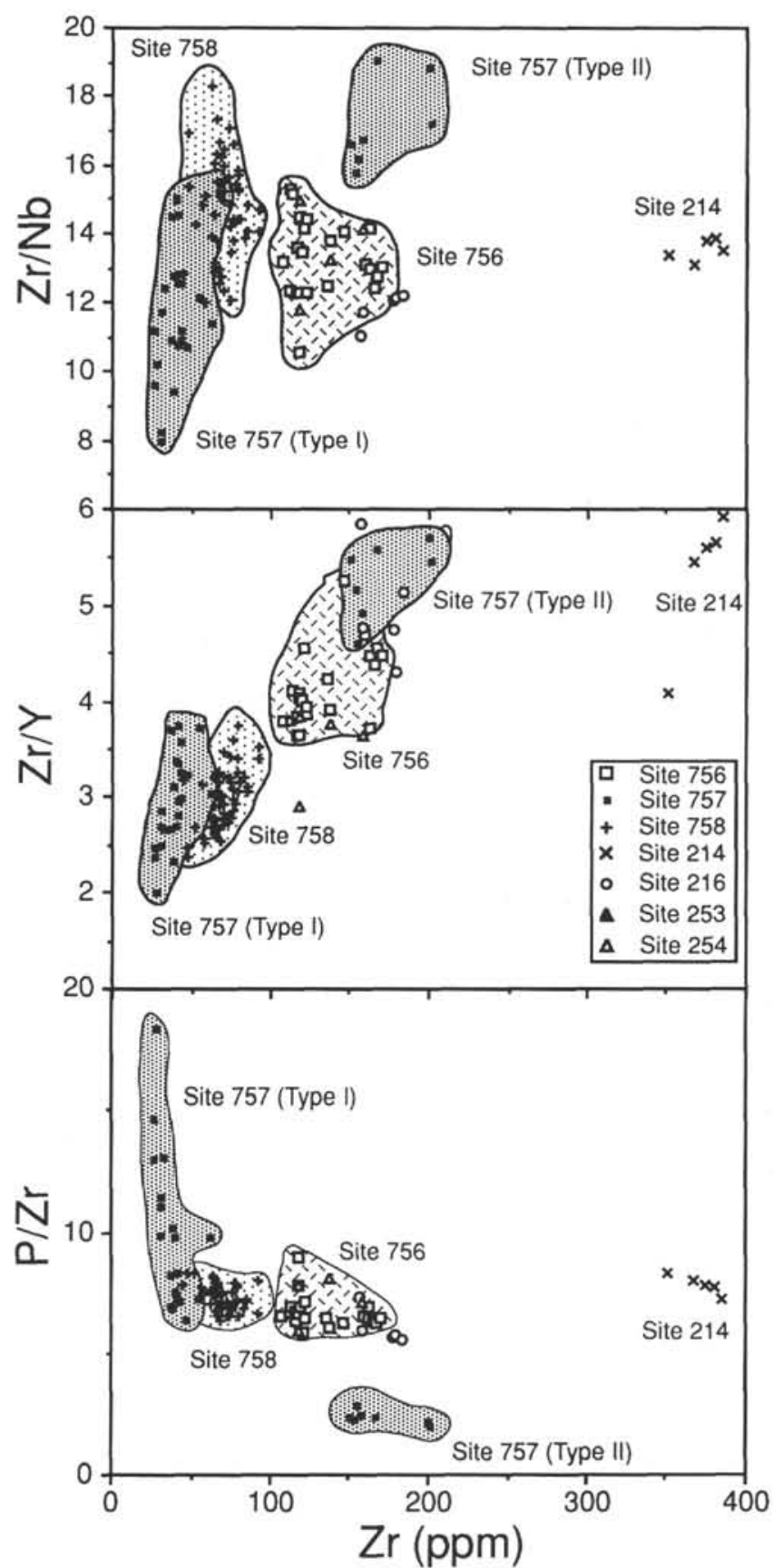

Figure 17. $\mathrm{Zr} / \mathrm{Nb}, \mathrm{Zr} / \mathrm{Y}$, and $\mathrm{P} / \mathrm{Zr}$ ratios vs. $\mathrm{Zr}$ in basalts from Sites 756,757 , and 758 , and DSDP Sites $214,216,253$, and 254 . Note the strong variation in the $\mathrm{P} / \mathrm{Zr}$ ratio, and to a lesser extent, in the $\mathrm{Zr} / \mathrm{Y}$ and $\mathrm{Zr} / \mathrm{Nb}$ ratios in the Type I basalts; such variation is not explained by plagioclase accumulation alone.

water, but the magmas may also have had a low volatile content and low oxygen fugacity. Note that there is no obvious difference, in terms of either trace elements or isotopes, between the pillowed lavas and the more massive flow units found at this site, indicating that the two sets of lavas were produced from isotopically identical source/magma supply systems. 


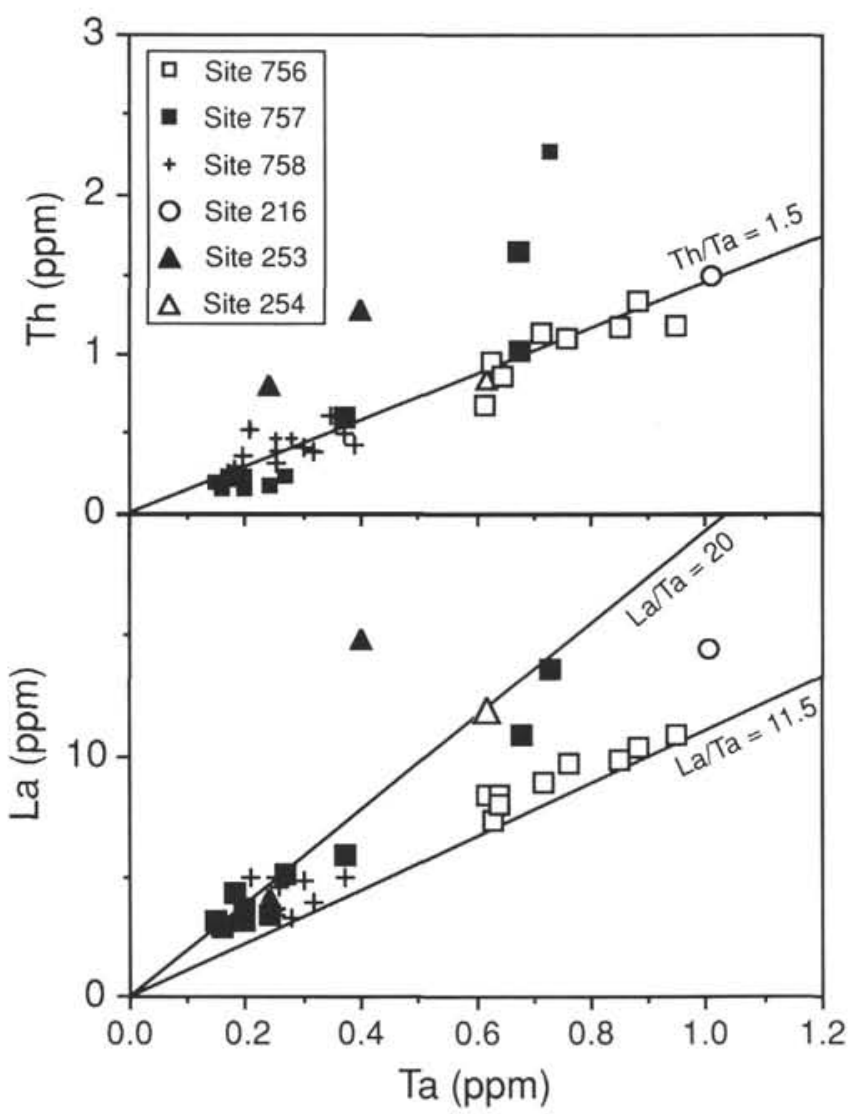

Figure 18. Abundances of Ta vs. Th and $\mathrm{La}$ in basalts from Sites 756, 757, and 758, and DSDP Sites 216, 253, and 254.

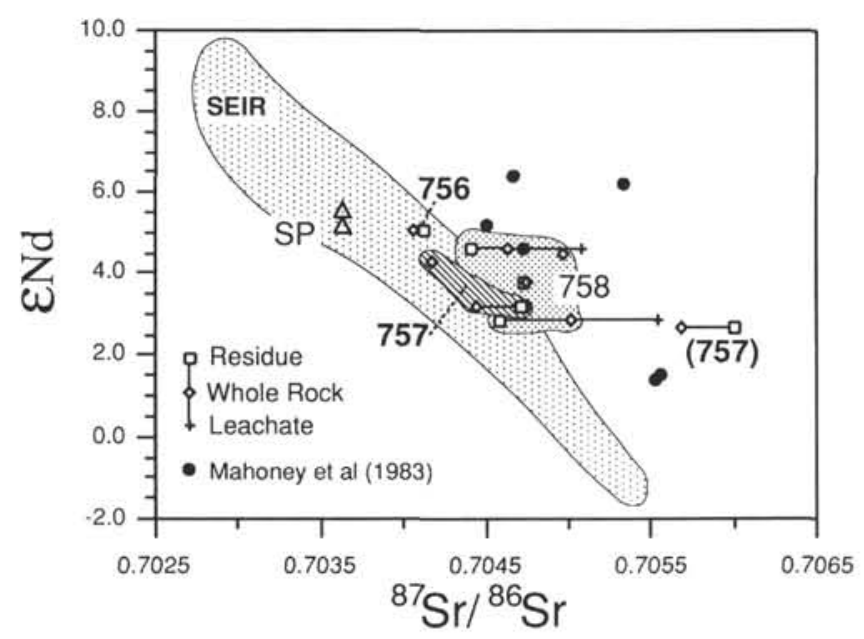

Figure 19. $\varepsilon N d$ vs. ${ }^{87} \mathrm{Sr} /{ }^{86} \mathrm{Sr}$ in Ninetyeast Ridge basalts and in basalts from other provinces in the Indian Ocean. SEIR = Southeast Indian Ridge basalts (Michard et al., 1986; Dosso et al., 1988); other NER data from Mahoney et al. (1983); SP = St. Paul Island data (Dupré and Allègre, 1983). $\varepsilon N d$ values were determined using ages basement listed in Tables 10 and 11 .

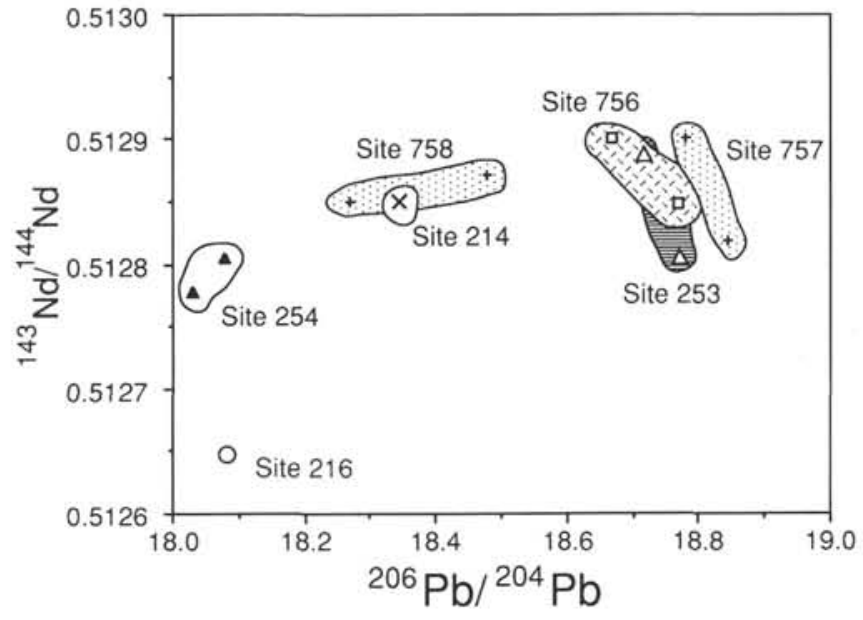

Figure 20. Expanded plot of ${ }^{143} \mathrm{Nd} / 144 \mathrm{Nd}$ vs. ${ }^{206} \mathrm{~Pb} / 204 \mathrm{~Pb}$ for basalts from Sites 756,757 , and 758 , and DSDP Sites $214,216,253$, and 254. All samples were acid-leached; no age correction has been made for lead isotopes because of the low predicted $\mathrm{U} / \mathrm{Pb}$ ratio of the leached residue of plagioclase and clinopyroxene.

The fractionation histories of Sites 214, 216, 253, and 254 have been dealt with by other workers and will not be covered here (see, for example, Ludden et al., 1980).

\section{Intersite Variations}

One of the most striking aspects of the Ninetyeast Ridge lavas is the limited range of rock types sampled in terms of major and trace element compositions. Notwithstanding the interunit variations at each site, most of which are explicable in terms of high-level fractionation, there are strong compositional similarities among Ninetyeast Ridge samples. For example, all of the samples, apart from the basal, olivine-rich basalt recovered at Site 253, are light REE-enriched basalts or ocean andesites with strong tholeiitic affinities. Even the few slightly $n e$-normative basalts probably owe their alkaline character to secondary processes. These data strongly suggest that the basalts were derived via a roughly constant melting process. The high, MORB-like Sc abundances rule out significant influence of garnet during the formation of the primary melts. Final melt equilibration probably occurred at high levels in the spinel stability field. Subsequent removal of pyroxene may be responsible for producing the low $\mathrm{Sc} / \mathrm{Zr}$ ratios of some liquids.

We can detect no temporal variations in magma compositioneither elemental or isotopic-along Ninetyeast Ridge. There are significant variations in isotope composition between the different sites, which suggests that the composition of the mantle source has varied, but these variations are not temporally significant. Ninetyeast Ridge thus appears reasonably well sampled even though there are only seven sites on a 5000-km-long structure.

\section{Ninetyeast Ridge and Mantle Plumes}

In this section we consider the origin of Ninetyeast Ridge in relation to the mantle plume systems of the southern Indian Ocean. We tacitly accept the plume model as outlined in the introduction to this account; the combination of paleomagnetic data, subsidence history, gravity data, and paleontological data, in addition to the broad geochemical observations made above, makes any other model unlikely. However, it is unclear which "plume" (as seen at the present day) is responsible for Ninetyeast Ridge activity; or indeed if only one plume was involved in the generation of the ridge. Furthermore, can we constrain whether the plume was located in an intraplate setting, like Hawaii, on a 


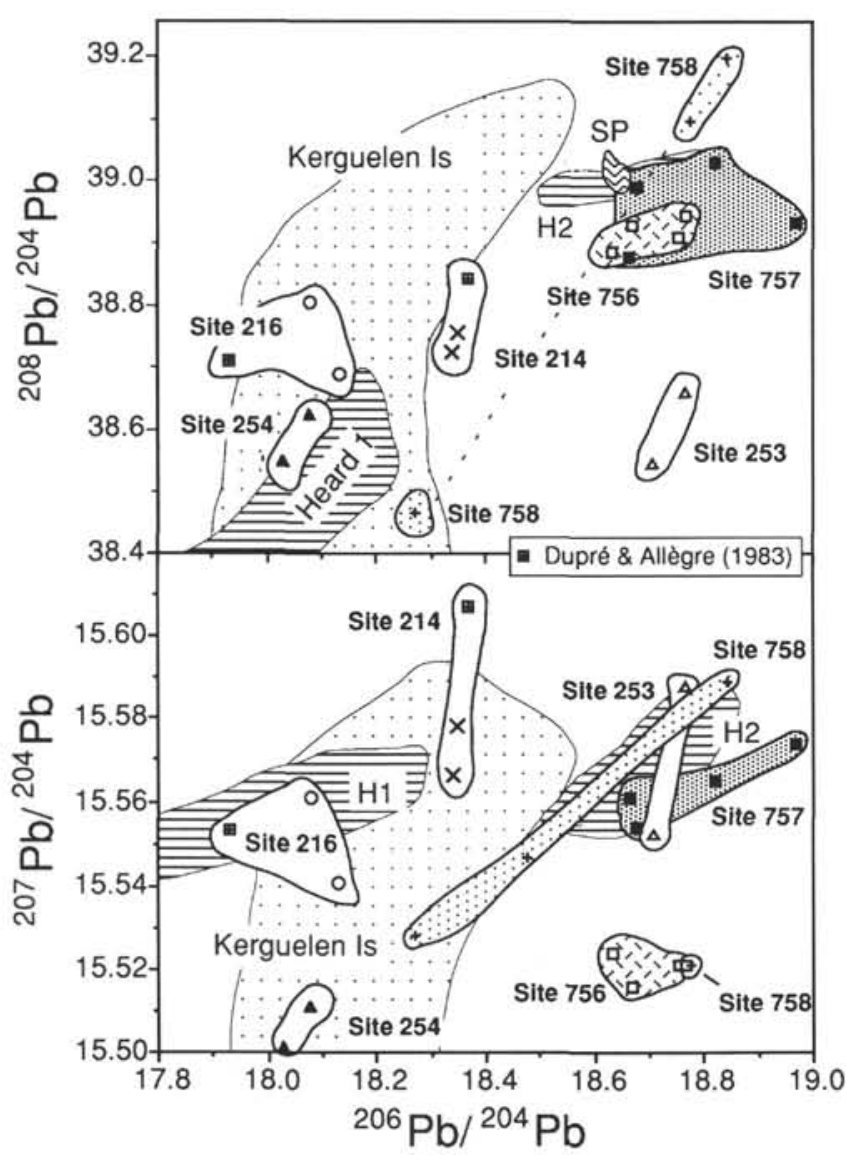

Figure 21. Expanded plot of ${ }^{207} \mathrm{~Pb} / 204 \mathrm{~Pb}$ and ${ }^{208} \mathrm{~Pb} / 204 \mathrm{~Pb}$ vs. ${ }^{206} \mathrm{~Pb} / 204 \mathrm{~Pb}$ for basalts from Sites 756, 757, and 758, and DSDP Sites 214, 216, 253, and 254. All samples were acid-leached; no age correction has been made for lead isotopes because of the low predicted $\mathrm{U} / \mathrm{Pb}$ and $\mathrm{Th} / \mathrm{Pb}$ ratios of the leached residue of plagioclase and clinopyroxene. Field for Kerguelen Island basalts is from data in Storey et al. (1988, and references therein); St. Paul Island (SP) data and previously published Site 216 and 214 data are from Dupré and Allègre (1983). $\mathrm{H} 1$ and $\mathrm{H} 2$ represent the two main subsets of isotope values determined for basalts from Heard Island (Barling and Goldstein, 1990). Note that the new $\mathrm{Pb}$ isotope data rule out an origin for the entire Ninetyeast Ridge through simple mixing of MORB mantle and Kerguelen Island mantle material. (MORB plot is below the $\mathrm{X}$-axis in both diagrams.)

ridge crest like Iceland, or close to a ridge crest, like the Galapagos Islands?

Modern settings in which rocks similar to those found on Ninetyeast Ridge occur have been extensively discussed by Frey et al. (1977). These include Iceland, Galapagos Islands, and Amsterdam/St. Paul islands, which presently straddle the Southeast Indian Ridge. All of these islands have erupted tholeiites and ferrobasalts and more evolved rocks, compositionally similar to those recovered from Ninetyeast Ridge. Even the light REE-depleted olivine basalts from Site 253 may have analogs on Iceland, where postulated remelting of the mantle has produced strongly depleted basalts (Wood, 1979). All of these islands share a similar tectonic setting, where a mantle hotspot has interacted with an extensional plate boundary. This makes them distinct from islands such as Hawaii, Réunion, or Heard, which at present are located within plates.

This distinction is important. McKenzie and Bickle (1988) and White and McKenzie (1989) have shown that melt generation is influenced by two important factors-the potential temperature of the mantle and the extension factor of the overlying lithosphere.

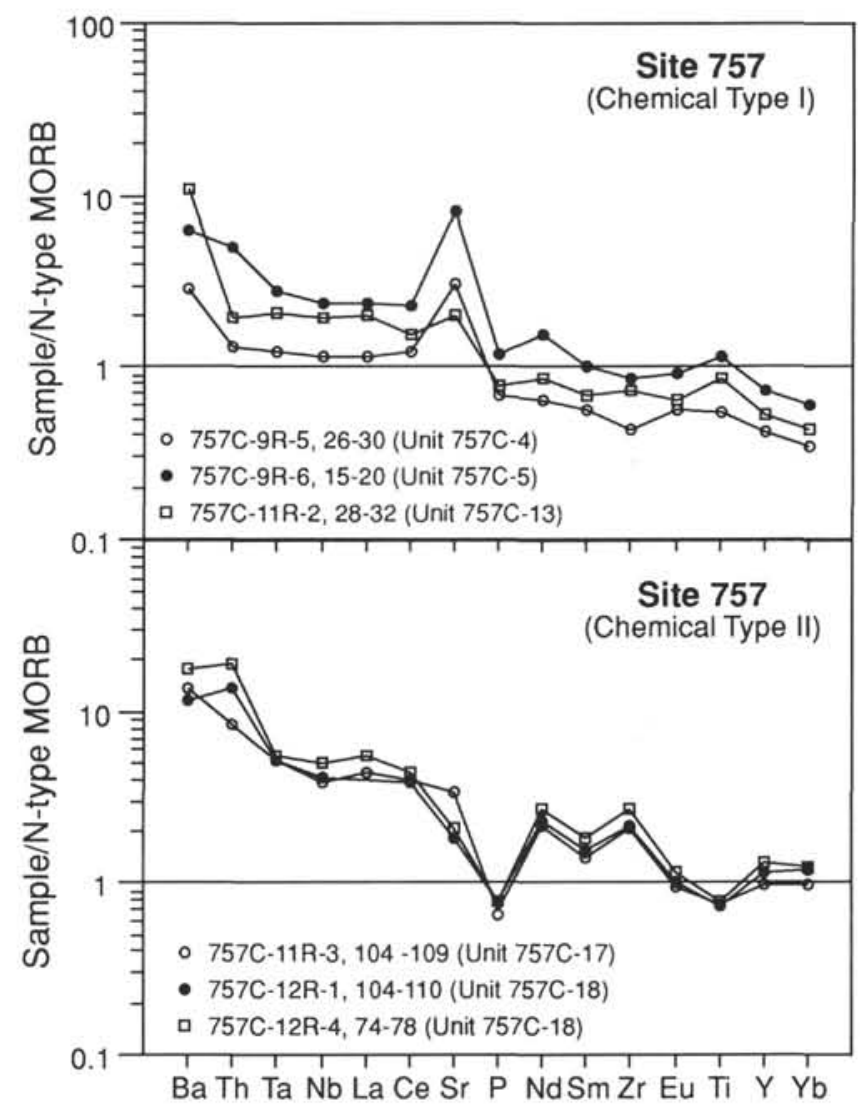

Figure 22. Abundances of incompatible elements in basalts of chemical types I and II from Site 757 normalized to N-type MORB. Note the high Sr abundances in the type I rocks, which are attributed to plagioclase accumulation. The Low $\mathrm{P}$ and $\mathrm{Ti}$ abundances in the type II rocks are attributed to pyroxene or apatite and titano-magnetite fractionation (see text). Normalizing values are from Sun and McDonough (1989).

Essentially, the higher the potential temperature of the mantle (i.e., the temperature the mantle would have if it rose adiabatically to the surface without melting) and the greater the extension factor, the larger the amount of melt that is generated. Thus, the ideal setting for voluminous melt generation is where a mantle plume with high potential temperature intersects a spreading axis. This results in a thickened crustal structure (e.g., Iceland, Faeroes, Kerguelen Plateau, Ontong-Java Plateau, etc.), where the dominant rock type produced is a tholeiitic basalt. Conversely, where a hotspot ascends beneath lithosphere, the melts are generated at greater depth and are more alkaline and incompatible element-enriched in character, and a far smaller volume is able to reach the surface.

A consequence of these models is that the major and compatible trace elements will be strongly controlled by the melting process rather than by the composition of the mantle plume. This could explain the similarities between the compositions of basaltic suites from islands as geographically diverse as Iceland and the Galapagos and St. Paul/Amsterdam islands. Conversely, the isotopic and highly incompatible trace element ratio characteristics of the erupted lavas, while they may be affected by mixing between different mantle sources, should largely be controlled by the composition of the plume (assuming that there has been minimal contamination en route to the surface).

Thus, although the major element compositions provide important information on the tectonic setting of Ninetyeast Ridge 

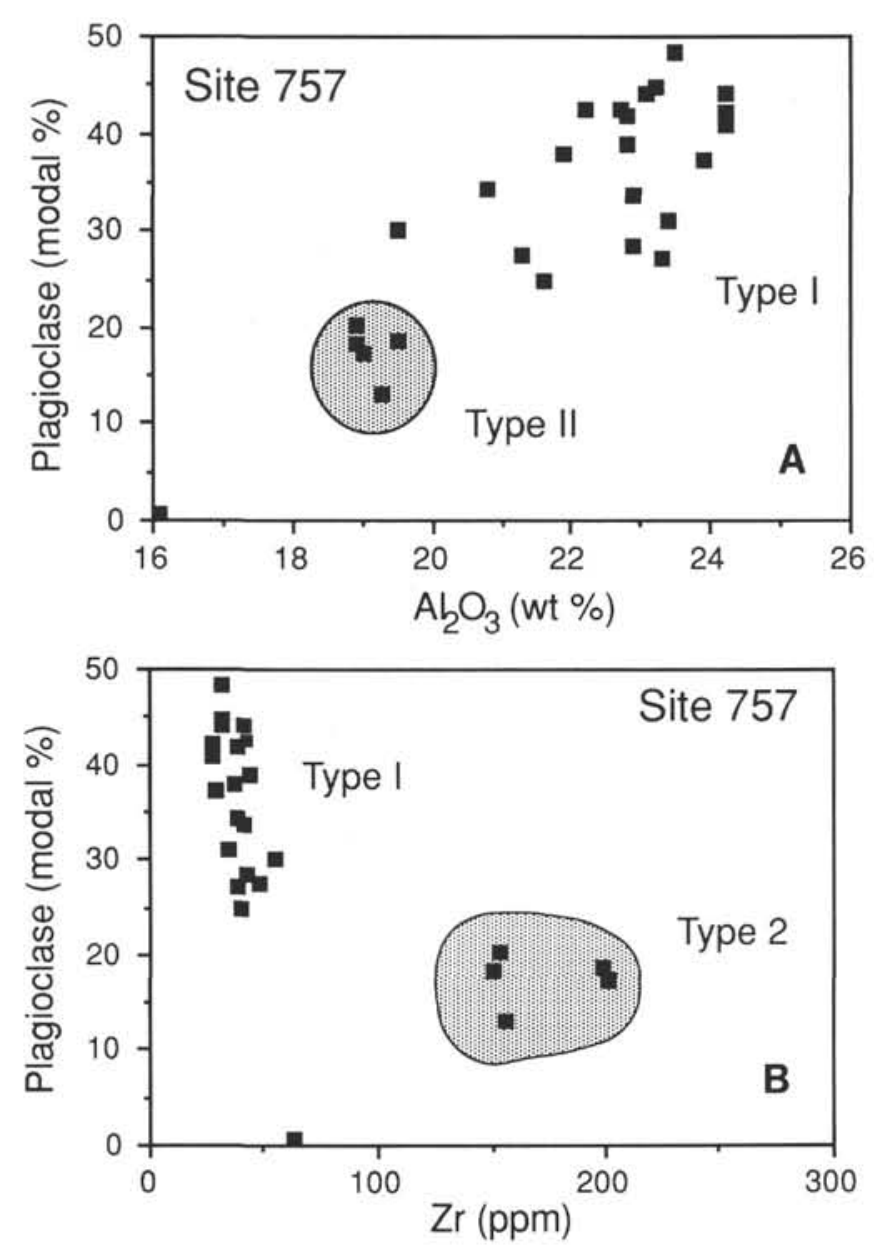

Figure 23. (A) $\mathrm{Al}_{2} \mathrm{O}_{3}$ and (B) $\mathrm{Zr}$ vs. modal plagioclase content in basalts from Site 757.

formation (i.e., intraplate vs. near- or on-ridge setting), they do not provide information about which plume was responsible. For this we must turn to isotopes and highly incompatible trace element data (e.g., Th, Ta, and La).

Limited isotope data for Ninetyeast Ridge have been available for several years. Reddy et al. (1978) showed that Ninetyeast Ridge rocks are enriched in ${ }^{87} \mathrm{Sr} /{ }^{86} \mathrm{Sr}(0.7043$ to 0.7049$)$ relative to Indian Ocean MORB $(<0.7035)$. Dupré and Allègre (1983) published $\mathrm{Pb}$ and $\mathrm{Sr}$ isotope data which demonstrated the high ${ }^{208} \mathrm{~Pb} /{ }^{204} \mathrm{~Pb}$ ratios of these samples, similar to some Kerguelen Island lavas, but with ${ }^{206} \mathrm{~Pb} /{ }^{204} \mathrm{~Pb}$ ratios less than those at St. Paul or Amsterdam islands. Limited ${ }^{143} \mathrm{Nd} /{ }^{144} \mathrm{Nd}$ data were also published by Mahoney et al. (1983).

The present study has considerably enlarged the available database. We do not propose to present an exhaustive study here but we note:

1. The new data extend Ninetyeast Ridge array to high ${ }^{206} \mathrm{~Pb} /{ }^{204} \mathrm{~Pb}$ values, approaching the values determined for $\mathrm{St}$. Paul Island. This is seen on the ${ }^{143} \mathrm{Nd} /{ }^{144} \mathrm{Nd}-{ }^{206} \mathrm{~Pb} /{ }^{204} \mathrm{~Pb}$ plot (Fig. 25) and the $\mathrm{Pb}$ isotope plots (Fig. 21).

2. Although the data overlap with the samples from Kerguelen/Heard islands with higher ${ }^{206} \mathrm{~Pb} /{ }^{204} \mathrm{~Pb}$ and ${ }^{208} \mathrm{~Pb} /{ }^{204} \mathrm{~Pb}$ and lower ${ }^{143} \mathrm{Nd} /{ }^{144} \mathrm{Nd}$ ratios, they do not fall on the mixing line between MORB and Kerguelen (Figs. 21 and 25). This does not rule out the involvement of MORB asthenosphere in the formation

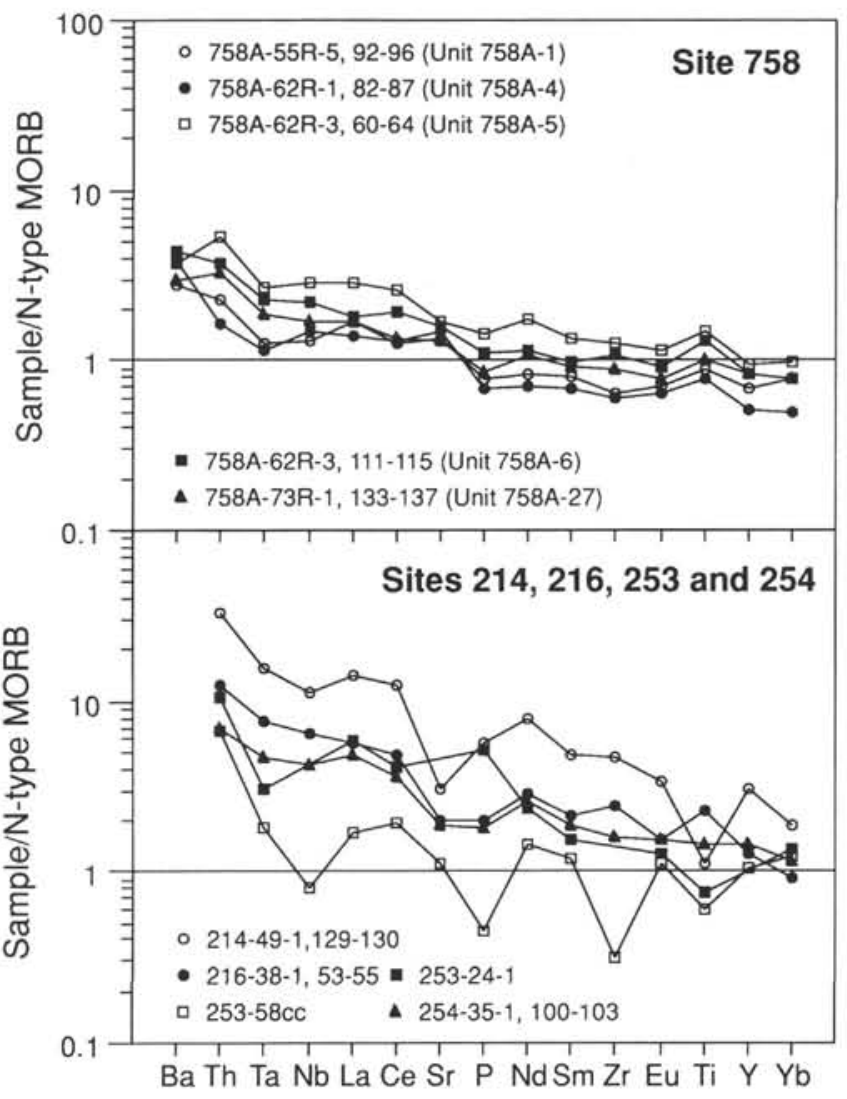

Figure 24. Abundances of incompatible elements in representative basalts from Site 758 and DSDP Sites $214,216,253$, and 254 normalized to N-type MORB. Normalizing values are from Sun and McDonough (1989).

of Ninetyeast Ridge but it does indicate that the $\mathrm{Pb}$ isotope data are dominated by components other than depleted MORB mantle (DMM: Zindler and Hart, 1986).

3. It is apparent on the ${ }^{143} \mathrm{Nd} /{ }^{144} \mathrm{Nd}$ vs. ${ }^{206} \mathrm{~Pb} /{ }^{204} \mathrm{~Pb}$ diagram (which is more reliable than ${ }^{87} \mathrm{Sr} /{ }^{86} \mathrm{Sr}$ vs. ${ }^{206} \mathrm{~Pb} /{ }^{204} \mathrm{~Pb}$ in the case of such altered rocks) that a subset of Indian Ocean MORB shows a distinct displacement toward lower ${ }^{143} \mathrm{Nd} /{ }^{144} \mathrm{Nd}$ and toward Ninetyeast Ridge field; this subset is the plume-elevated section of the Southeast Indian Ridge adjacent to St. Paul/Amsterdam islands and between Kerguelen Island and the southern tip of Ninetyeast Ridge (Michard et al., 1986; Storey et al., 1988).

4. Ninetyeast Ridge data show a trend toward a high ${ }^{206} \mathrm{~Pb} /{ }^{204} \mathrm{~Pb}$ end member which has not been previously observed in this region of the Indian Ocean, apart from in basalts recovered from St. Paul/Amsterdam islands (e.g., Dupré and Allègre, 1983) and more recently on Heard Island (Barling and Goldstein, 1990).

5. The high ${ }^{208} \mathrm{~Pb} /{ }^{204} \mathrm{~Pb},{ }^{207} \mathrm{~Pb} /{ }^{204} \mathrm{~Pb}$, and ${ }^{143} \mathrm{Nd} /{ }^{206} \mathrm{~Pb}$ ratios in Ninetyeast Ridge lavas indicate that Ninetyeast Ridge was sampling mantle with an "enriched mantle" component (Zindler and Hart, 1986), possibly similar to that being sampled by Kerguelen and Heard islands (Dosso et al., 1979; Storey et al., 1988), but mixed with other components. Broadly speaking, Ninetyeast Ridge has sampled Dupal mantle (Hart, 1984), but the enrichment is not as extreme as that seen in lavas from Kerguelen and Heard islands or the Kerguelen Plateau (Storey et al., 1988, in press; Davies et al., 1989; Weis et al., 1989). Note that Barling and Goldstein (1990) have recently demonstrated a large isotopic array for lavas from Heard Island (these data are included for 


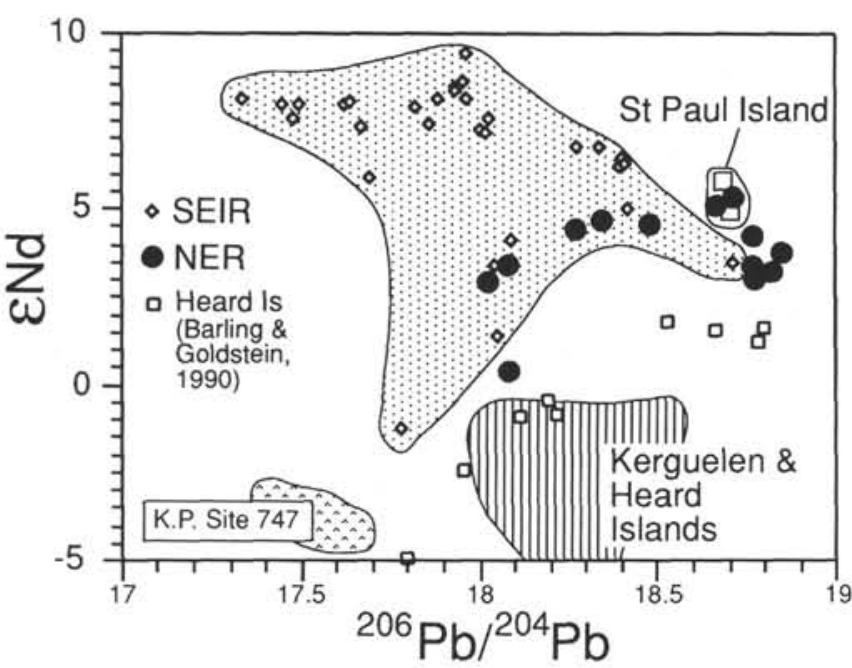

Figure 25. Plot of $\varepsilon N d$ vs. ${ }^{206} \mathrm{~Pb} / 204 \mathrm{~Pb}$ for basalts from Ninetyeast Ridge (this chapter), Southeast Indian Ridge (SEIR) (Michard et al., 1986; Dosso et al., 1988), St. Paul Island (Dupré and Allègre, 1983), Kerguelen Island (Storey et al., 1988, and references therein), Site 747 of the Kerguelen Plateau (Storey et al., in press), and Heard Island (Storey et al., 1988; Barling and Goldstein, 1990). As with the $\mathrm{Pb}$ isotope data, we must rule out an origin for the entire Ninetyeast Ridge through simple mixing of MORB mantle and Kerguelen Island mantle material.

reference in the various isotope diagrams), which encompasses the range of ${ }^{206} \mathrm{~Pb} /{ }^{204} \mathrm{~Pb}$ ratios measured in Ninetyeast Ridge basalts.

Trace element data provide limited constraints to these models. The shipboard party by plotting element ratios (e.g., Y/Nb vs. $\mathrm{Zr} / \mathrm{Nb}$ ) demonstrated the transitional nature of Ninetyeast Ridge lavas (Peirce, Weissel, et al., 1989). All of the lava compositions lie between ocean island basalts (specifically, Kerguelen and Heard islands) and MORB on this plot. However, these ratios are susceptible to fractionation during partial melting, and may reflect the decreased percentage of melting and deep melting that characterizes ocean island basalt generation. Furthermore, this type of plot is unable to discriminate between different types of ocean island basalt: most ocean island basalts are characterized by low $\mathrm{Zr} / \mathrm{Nb}$ and $\mathrm{Zr} / \mathrm{Y}$ ratios.

Of more value in fingerprinting mantle compositions are ratios of the highly incompatible elements $\mathrm{Rb}, \mathrm{Ba}, \mathrm{K}, \mathrm{La}, \mathrm{Ta}, \mathrm{Th}$, and $\mathrm{Nb}$. Unfortunately, because of the highly altered state of Ninetyeast Ridge lavas, $\mathrm{Rb}, \mathrm{Ba}$, and $\mathrm{K}$ cannot be used with any degree of certainty, and the abundances of $\mathrm{Ta}$ and $\mathrm{Nb}$ in several suites of lavas are so low that the data must be used with caution. Nonetheless, the following observations may be made: Ninetyeast Ridge lavas exhibit a range of $\mathrm{La} / \mathrm{Ta}$ from about 12 to more than 20 (one ratio of 37 should be treated with caution until verified) (Figs. 19, 26, and 27, and Table 10). The values of 12 are similar to those found in ocean island basalts (e.g., Iceland: Wood et al., 1979a; Pacific islands: Palacz and Saunders, 1986) and some enriched MORB (for example, the Mid-Atlantic Ridge at $45^{\circ} \mathrm{N}$; Wood et al., 1979b). The higher values are more typical of depleted or N-type MORB.

The range of $\mathrm{La} / \mathrm{Ta}$ values in Ninetyeast Ridge lavas is surprising, considering that this ratio retains remarkable consistency throughout the Icelandic basalts (10: Wood et al., 1979a). It suggests Ninetyeast Ridge has sampled a heterogeneous source with both plume and MORB-like components and that different sites have recovered material derived with subtly different proportions of the mantle types. Unfortunately, like the $\mathrm{Nb} / \mathrm{Zr}$ vs.
$\mathrm{Y} / \mathrm{Nb}$ plot, $\mathrm{La} / \mathrm{Ta}$ does not adequately discriminate the type of plume being sampled (i.e., most plumes are associated with lavas with low $\mathrm{La} / \mathrm{Ta}$ ratios). There is an additional complication to consider. It has been suggested that high $\mathrm{La} / \mathrm{Ta}$ ratios are characteristic of basaltic melts derived from the continental lithosphere (see, for example, Storey et al., 1989; Saunders et al., 1988). These melts are also characterized by high $\mathrm{Th} / \mathrm{Ta}$ ratios (see Fig. 27). Do Ninetyeast Ridge lavas show this feature? There is a reason for asking this question. The Kerguelen Plateau, which was probably formed above the same hotspot system that formed Ninetyeast Ridge, is compositionally very heterogeneous, and the $\mathrm{Pb}$ isotope data clearly indicate that the lavas represent more components than simply mixing between MORB and plume. Storey et al. (in press) have suggested that the lavas with low ${ }^{206} \mathrm{~Pb} /{ }^{204} \mathrm{~Pb}$ ratios (e.g., Site 747 included on Fig. 25) were derived from mantle with a component derived from the sub-Gondwana lithosphere.

It is not apparent that such a component is present in Ninetyeast Ridge lavas. On the $\mathrm{La} / \mathrm{Ta}$ vs. Th/Ta diagram (Fig. 27), Ninetyeast Ridge lavas fall in a broad field in the vicinity of MORB and Kerguelen and Heard islands, and overlap with samples from the Kerguelen Plateau. Further work is required to evaluate these data.

\section{CONCLUSIONS}

1. The ODP sites have corroborated earlier DSDP studies that Ninetyeast Ridge is built predominantly of light REE-enriched tholeiitic basalts. At individual sites, the basalts show a range of compositions that at least semiquantitatively can be related by fractional crystallization or other high-level processes.

2. Basalts from the lower section of Site 757 have an evolved composition that shows several characteristics found in the oceanic andesites recovered at Site 214.

3. The behavior of Eu and $\mathrm{Ti}$ in the lavas from Site 757 and the occurrence of low-Ti andesites at Site 214 suggests that the magmas have a high oxygen fugacity. This in turn may account for the high degree of vesicularity in at least the Site 757 lavas. The suggestion that these lavas were erupted in a subaerial environment should be reevaluated in the light of these observations.

4. Each site has distinctive isotopic characteristics and there are significant differences between the sites, suggesting that Ninetyeast Ridge has sampled a mantle source with a varied composition. This is not unexpected considering the volume of the magmatic products that form Ninetyeast Ridge or the isotopic heterogeneity reported for Kerguelen and Heard islands (Storey et al., 1988; Barling and Goldstein, 1990).

5. The new isotope data show that Ninetyeast Ridge cannot be generated only by simple mixing between the Kerguelen mantle plume and MORB asthenosphere, nor by mixing between St. Paul/Amsterdam plume material and MORB mantle. It is possible that the ridge represents a collage of eruptive products from several plumes, as proposed by Luyendyk and Rennick (1977), but recent studies of Heard Island clearly demonstrate that most if not all of the required components are presently available beneath that island (Barling and Goldstein, 1990), suggesting that the system is more complex than hitherto realized.

6. The similarity between Ninetyeast Ridge lavas and ocean islands which lie on or adjacent to constructive plate boundaries almost certainly reflects the processes of magma generation in such an environment, and the major element characteristics of such islands probably cannot be used to identify the parent plume of Ninetyeast Ridge (for example, although St. Paul/Amsterdam islands comprise tholeiites and ferrobasalts like those found on Ninetyeast Ridge, this probably reflects a similar tectonic setting of the islands and the ridge during its formational stages). 


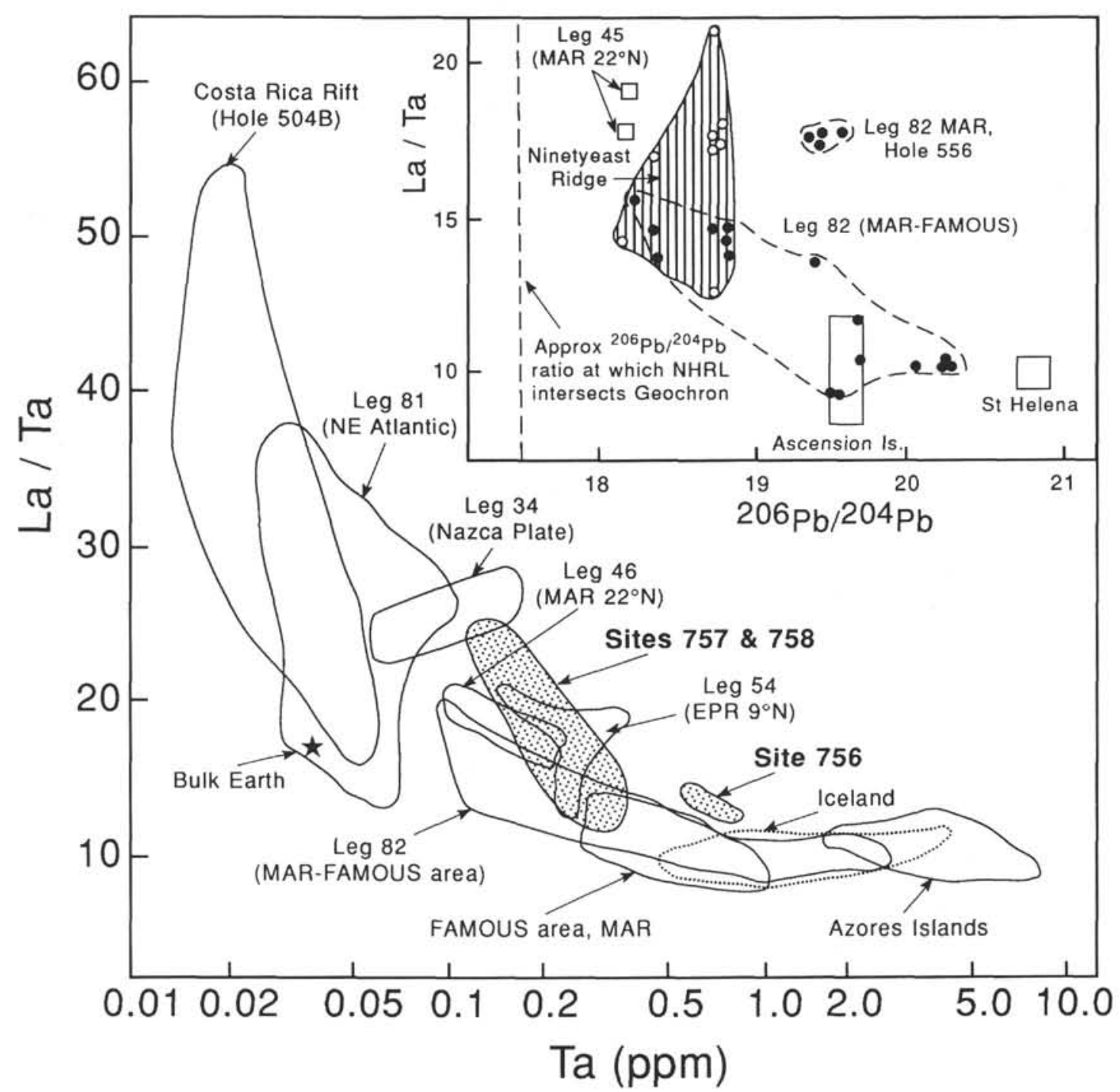

Figure 26. Abundance of Ta vs. La/Ta ratio basaltic rocks from Ninetyeast Ridge in comparison with basalts from other localities. Diagram modified from, and reference to fields contained in, Saunders (1986).

\section{REFERENCES}

Alt, J. C., Honnorez, J., Laverne, C., and Emmermann, R., 1986. Hydrothermal alteration of a 1-km section through the upper oceanic crust, Deep Sea Drilling Project Hole 504B: mineralogy, chemistry, and evolution of seawater-basalt interactions. J. Geophys. Res., 91:10309-10335

Andrews, A. J., Barnett, R. L., MacClement, B.A.E., Fyfe, W. S., Morrison, G., MacRae, N. D., and Starkey, J., 1977. Zeolite facies metamorphism, geochemistry and some aspects of trace element redistribution in altered basalts of DSDP, Leg 37. In Aumento, F., Melson, W. G., et al., Init. Repts. DSDP, 37: Washington (U.S. Govt. Printing Office), 795-810.

Barling, J., and Goldstein, S. L., 1990. Extreme isotopic variations in Heard Island lavas and the nature of mantle reservoirs. Nature, 348:59-62.

Bass, M. N., 1976. Secondary minerals in oceanic basalt, with special reference to Leg 34, Deep Sea Drilling Project. In Yeats, R. S., Hart, S. R., et al., Init. Repts. DSDP, 34: Washington (U.S. Govt. Printing Office), 393-432.
Bass, M. N., Moberly, R., Rhodes, J. M., Shih, C. S., and Church, S. E., 1973. Volcanic rocks cored in the central Pacific, Leg 17, Deep Sea Drilling Project. In Winterer, E. L., Ewing, J. I., et al., Init. Repts. DSDP, 17: Washington (U.S. Govt. Printing Office), 429-503.

Bohkle, J. K., Honnorez, J., Honnorez-Guerstein, B. M., 1980. Alteration of basalts from Site 396B, DSDP: petrographic and mineralogical studies. Mineral. Petrol., 73:341-364.

Bowin, C., 1973. Origin of the Ninety East Ridge from studies near the Equator. J. Geophys. Res., 78:6029-6043.

Davies, H. L., Sun, S.-S., Frey, F. A., Gautier, I., McCulloch, M. T., Price, R. C., Bassias, Y., Klootwijk, C. T., and Leclaire, L., 1990. Basalt basement from the Kerguelen Plateau and the trail of the Dupal plume. Contrib. Mineral. Petrol., 103:457-469.

Davies, T. A., Luyendyk, B. P., et al., 1974. Init. Repts., DSDP, 26: Washington (U.S. Govt. Printing Office).

Dosso, L., Bougault, H., Beuzart, P., Calvez, J.-Y., and Joron, J.-L., 1988. The geochemical structure of the South East Indian Ridge. Earth Planet. Sci. Lett., 88:47-49.

Dosso, L., Vidal, P., Cantagrel, J. M., Lameyre, J., Marot, A., and Zimine, S., 1979. "Kerguelen: continental fragment or oceanic island?": 
petrology and isotopic geochemistry evidence. Earth Planet. Sci. Lett., 43:46-60.

Duncan, R. A., 1978. Geochronology of basalts from the Ninetyeast Ridge and continental dispersion in the eastern Indian Ocean. J. Volcanol. Geotherm. Res., 4:283-305.

Dupré, B., and Allègre, C. J., 1983. Pb-Sr isotope variation in Indian Ocean basalts and mixing phenomena. Nature, 303:142-146.

Francis, T.J.G., and Raitt, R. W., 1967. Seismic refraction measurements in the southern Indian ocean. J. Geophys. Res., 72:3015-3041.

Frey, F. A., Dickey, J. S., Jr., Thompson, G., and Bryan, W. B., 1977. Eastern Indian Ocean DSDP sites: correlations between petrology, geochemistry and tectonic setting. In Heirtzler, J. R., Bolli, H. M., Davies, T. A., Saunders, J. B., and Sclater, J. G. (Eds.), Indian Ocean Geology and Biostratigraphy: Am. Geophys. Union, 189-257.

Frey, F. A., and Sung, C. M., 1974. Geochemical results for basalts from sites 253 and 254. In Davies, T. A., Luyendyk, B. P., et al., Init. Repts. DSDP, 26: Washington (U.S. Govt. Printing Office), 567-572.

Govindaraju, K., 1984. 1984 compilation of working values and sample description for 170 international reference samples of mainly silicate rocks and minerals. Spec. Iss. Geostds. Newsl., 8. 1989. Spec. Iss. Geostds. Newsl., 13.

Hart, S. R., 1984. A large scale isotope anomaly in the Southern Hemisphere mantle. Nature, 309:753-757.

Hekinian, R., 1974a. Petrology of igneous rocks from Leg 22 in the northeastern Indian Ocean. In von der Borch, C. C., Sclater, J. G., et al., Init. Repts. DSDP, 22: Washington (U.S. Govt. Printing Office), 413-447.

1974b. Petrology of the Ninetyeast Ridge (Indian Ocean) compared to other aseismic ridges. Contrib. Mineral. Petrol., 43:125147.

Kempe, D.R.C., 1974. The petrology of the basalts, Leg 26. In Davies, T. A., Luyendyk, B. P., et al., Init. Repts. DSDP, 26: Washington (U.S. Govt. Printing Office), 465-503.

Leat, P. T., Thompson, R. N., Morrison, M. A., Hendry, G. L., and Dickin, A. P., 1990. Geochemistry of mafic lavas in the early Rio Grande Rift, Yarmony Mountain, Colorado, USA. Chem. Geol., 81:23-43.

Le Pichon, X., and Heirtzler, J. R., 1968. Magnetic anomalies in the Indian Ocean and sea-floor spreading. J. Geophys. Res., 73:21012117.

Ludden, J. L., Thompson, G., Bryan W. B., and Frey, F. A., 1980. The origin of lavas from the Ninetyeast Ridge, eastern Indian Ocean: an evaluation of fractional models. J. Geophys. Res., 85:4405-4420.

Luyendyk, B. P., and Davies, T. A., 1974. Results of DSDP Leg 26 and the geologic history of the Southern Indian Ocean. In Davies, T. A., Luyendyk, B. P., et al., Init. Repts. DSDP, 26: Washington (U.S. Govt. Printing Office), 909-943.

Luyendyck, B. P., and Rennick, W., 1977. Tectonic history of aseismic ridges in the eastern Indian Ocean. Geol. Soc. Am. Bull., 88:13471356.

Mahoney, J. J., 1987. An isotopic survey of Pacific oceanic plateaus: implications for their nature and origin. In Keating, B. H., Fryer, P., Batiza, R., and Boehlert, G. W. (Eds.), Seamounts, Islands, and Atolls. Am. Geophys. Union Monogr., 43:207-220.

Mahoney, J. J., Macdougall, J. D., Lugmair, G. W., and Gopalan, K., 1983. Kerguelen hotspot source for Rajmahal Traps and Ninetyeast Ridge? Nature, 303:385-389.

McKenzie, D., Bickle, M. J., 1988, The volume and composition of melt generated by extension of the lithosphere. J. Petrol., 29:625-679.

Michard, A., Montigny, R., and Schlich, R., 1986. Geochemistry of the mantle beneath the Rodriguez Triple Junction and the South-East Indian Ridge. Earth Planet. Sci. Lett., 78:104-114.

Morgan, J., 1972. Plate motions and deep mantle convection. Mem. Geol. Soc. Am. Mem., 132:7-72.

Mutter, J. C., and Cande, S. C., 1983. The early opening between Broken Ridge and Kerguelen Plateau. Earth Planet. Sci. Lett., 65:369-376.

Nakamura, N., 1974. Determination of REE, Ba, Fe, $\mathrm{Mg}, \mathrm{Na}$, and $\mathrm{K}$ in carbonaceous and ordinary chondrites. Geochim. Cosmochim. Acta 44:1917-1930.

Palacz, Z. A., and Saunders, A. D., 1986. Coupled trace element and isotope enrichment in the Cook-Austral-Samoa islands, southwest Pacific. Earth Planet. Sci. Lett., 79:270-280.

Peterson, C., Duncan, R., and Scheidegger, K. F., 1986. Sequence and longevity of basalt alteration at Deep Sea Drilling Project site 597. In
Leinen, M., Rea, D. K., et al., Init. Repts. DSDP, 92: Washington (U.S. Govt. Printing Office), 505-515.

Peirce, J., Weissel, J., et al., 1989. Proc. ODP, Init. Repts., 121: College Station, TX (Ocean Drilling Program).

Peirce, J. W., 1978. The northward motion of India since the Late Cretaceous. Geophys. J. R. Astron. Soc., 52:277-311.

Peirce, J. W., Denham, C. R., and Luyendyk, B. P., 1974. Paleomagnetic results of basalt samples from DSDP Leg 26, Southern Indian Ocean. In Luyendyk, B. P., Davies, T. A., et al., Init. Repts. DSDP, 26 Washington (U.S. Govt. Printing Office), 517-527.

Price, R. C., Kennedy, A. K., Riggs-Sneeringer, M., and Frey, F. A., 1986. Geochemistry of basalts from the Indian Ocean triple junction: implications for the generation and evolution of Indian Ocean ridge basalts. Earth Planet. Sci. Lett., 78:379-396.

Prudencio, M. I., Gouveia, M. A., and Cabral, J.M.P., 1986. Instrumental neutron activation analysis of two French geochemical reference samples-basalt BR and biotite Mica-Fe. Geostds. Newsl., 10:29-31.

Reddy, V. V., Subbaroa, K. V., Reddy, G. R., Matsuda, J., and Hekinian, R., 1978. Geochemistry of volcanics from the Ninetyeast Ridge and its vicinity in the Indian Ocean. Mar. Geol., 26:99-117.

Saunders, A. D., 1986. Geochemistry of basalts from the Nauru Basin, Deep Sea Drilling Project Legs 61 and 89: implications for the origin of oceanic flood basalts. In Moberly, R., Schlanger, S. O., et al., Init. Repts. DSDP, 89: Washington (U.S. Govt. Printing Office), 499-517.

Saunders, A. D., Norry, M. J., and Tarney, J. 1988. Origin of MORB and chemically depleted mantle reservoirs: trace elements constraints. $J$. Petrol. (Spec. Lithospheric Iss.), 415-445.

Schubert, G., and Sandwell, D., 1989. Crustal volumes of the continents and of oceanic and continental submarine plateaus. Earth Planet. Sci. Lett., 92:234-246.

Sclater, J. G., and Fisher, R. L., 1974. The evolution of the east central Indian Ocean with emphasis on the tectonic setting of the Ninetyeast Ridge. Geol. Soc. Am. Bull., 85:683-702.

Sclater, J. G., von der Borch C., Veevers, J. J., Hekinian, R., Thompson, R. W., Pimm, A. C., McGowran, B., Gartner, S., Jr., and Johnson, D. A. 1974. Regional synthesis of the Deep Sea Drilling result from Leg 22 in the Eastern Indian Ocean. In von der Borch, C., Sclater, J. G., et al., Init. Repts. DSDP, 22: Washington (U.S. Govt. Printing Office), 815-831.

Shipboard Scientific Party, 1989. Ninetyeast Ridge summary. In Peirce, J., Weissel, J., Proc. ODP, Init. Repts., 121: College Station, TX (Ocean Drilling Program), 517-537.

Stakes, D. S., and O'Neill, J. R., 1982. Mineralogy and stable isotope geochemistry of hydrothermally altered oceanic rocks. Earth Planet. Sci. Lett., 57:285-304.

Storey, M., Kent, R., Saunders, A. D., Salters, V. J., Hergt, J., Whitechurch, H., Sevigny, J. H., Thirlwall, M. F., Leat, P., Ghose, N. C., Gifford, M., in press. Lower Cretaceous volcanic rocks on continental margins and their relationship to the Kerguelen Plateau. In Schlich, R., Wise, S. W., Jr., Proc. ODP, Sci. Results, 120: College Station, TX (Ocean Drilling Program).

Storey, M., Saunders, A. D., Tarney, J., Gibson, A. L., Norry, M. J., Thirlwall, M. F., Leat, P., Thompson, R. N., and Menzies, M. A., 1989. Contamination of Indian Ocean asthenosphere by the KerguelenHeard mantle plume. Nature, 338:574-576.

Storey, M., Saunders, A. D., Tarney, J., Leat, P., Thirlwall, M. F. Thompson, R. N., Menzies, M. A., and Marriner, G. F., 1988. Geochemical evidence for plume-mantle interactions beneath Kerguelen and Heard islands, Indian Ocean. Nature, 336:371-374.

Subbarao, K. V., Hekinian, R., Chandresekharen, D., 1977. Large ion lithophile elements and $\mathrm{Sr}$ and $\mathrm{Pb}$ isotopic variations in volcanic rocks from the Indian Ocean. In Heirtzler, J. R., Bolli, H. M., Davies, T. A., Saunders, J. B., and Sclater, J. G. (Eds.), Indian Ocean Geology and Biostratigraphy. Am. Geophys. Union Monogr., 259-278.

Sun, S.-S., and McDonough, W. F., 1989. Chemical and isotopic systematics of oceanic basalts: implications for mantle composition and processes. In Saunders, A. D., and Norry, M. J. (Eds.), Magmatism in the Ocean Basins. Geol. Soc. Spec. Publ. London, 42:313-345.

Thompson, G., Bryan, W. B., Frey, F. A., and Sung, C. M., 1974. Petrology and geochemistry of basalts and related rocks from Sites $214,215,216$, DSDP Leg 22, Indian Ocean. In von der Borch, C. C., and Sclater, J. G., et al., Init. Repts. DSDP, 22: Washington (U.S. Govt. Printing Office), 459-468. 


\section{A. D. SAUNDERS ET AL.}

von der Borch, C. C., Sclater, J. G., et al., 1974. Init. Repts. DSDP, 22: Washington (U.S. Govt. Printing Office).

Weis, D., Bassias, Y., Gautier, I., and Mennesier, J.-P., 1989. DUPAL anomaly in existence $115 \mathrm{Ma}$ ago: evidence from isotopic study of the Kerguelen Plateau (South Indian Ocean). Geochim. Cosmochim. Acta, 53:2125-2131.

White, R. S., and McKenzie, D., 1989. Magmatism at rift zones: the generation of volcanic continental margins and flood basalts. J. Geophys. Res., 94:7685-7729.

Wood, D. A., 1978. Major and trace element variations in the Tertiary lavas of eastern Iceland with respect to the Iceland geochemical anomaly. J. Petrol., 19:393-436

1979. Dynamic partial melting: its application to the petrogenesis of basalts erupted in Iceland, the Faeroe Islands, the Isle of Skye (Scotland) and the Troodos Massif (Cyprus). Geochim. Cosmochim. Acta, 43:1031-1046.
Wood, D. A., Joron, J. L., Treuil, M., Norry, M. J., and Tarney, J., 1979. Elemental and $\mathrm{Sr}$ isotope variations in basic lavas from Iceland and the surrounding ocean floor. Contrib. Mineral. Petrol., 70:319-339.

Wood, D. A., Tarney, J., Varet, J., Saunders, A. D., Bougault, H., Joron, J.-L., Treuil, M., and Cann, J. R., 1979b. Geochemistry of basalts drilled in the North Atlantic by IPOD Leg 49: implications for mantle heterogeneity. Earth Planet. Sci. Lett., 42:77-97.

Zindler, A., and Hart, S., 1986. Chemical geodynamics. Annu. Rev. Earth Planet. Sci., 14:493-571.

Date of initial receipt: 7 March 1990 Date of acceptance: 13 November 1990 Ms 121B-169

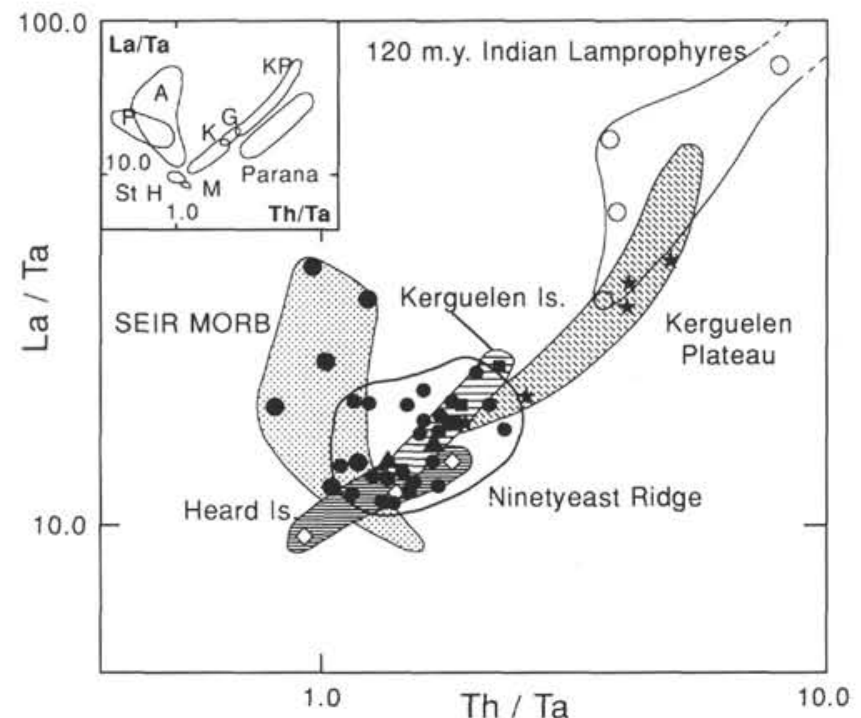

Figure 27. $\mathrm{La} / \mathrm{Ta}$ vs. Th/Ta ratio in basaltic rocks from Ninetyeast Ridge in comparison with basalts from other localities. Diagram modified from Storey et al. (1989). Key to inset: $A=$ Atlantic MORB, $P=$ Pacific MORB, $\mathrm{St} H=\mathrm{St}$. Helena, $\mathrm{M}=$ Mangaia Island, $\mathrm{K}=$ Kerguelen Island, $\mathrm{G}=\mathrm{Gough}$ Island, $\mathrm{KP}=$ Kerguelen Plateau, Parana = Parana flood basalts, Brazil. References for data sources given in Storey et al. (1989). 


\section{APPENDIX \\ INTERLABORATORY GEOCHEMICAL REFERENCE STANDARDS}

\section{A. D. Saunders, ${ }^{2}$ F. A. Frey, ${ }^{8}$ I. L. Gibson, ${ }^{3}$ and D. Weis ${ }^{9}$}

Basalts recovered during Leg 121 of the Ocean Drilling Program have been analyzed for major and trace elements by several laboratories using a variety of techniques. To enable shipboard and shore-based workers to monitor accuracy of laboratory methods, and to make direct comparisons between the different sets of data reported in this volume, each laboratory analyzed an aliquot of six Leg 121 samples that were selected as interlaboratory standards.

\section{Sample Preparation}

Six large (up to 8-cm-long) quarter-portions of macroscopically homogeneous core were selected. The sampling intervals chosen were: 121-756D-6R-3, 0-8 cm; 121-756D-12R-2, 28-33 cm; 121-757C-9R-2, $0-10 \mathrm{~cm} ; 121-757 \mathrm{C}-12 \mathrm{R}-1,104-110 \mathrm{~cm} ; 121-758 \mathrm{~A}-66 \mathrm{R}-4,6-12 \mathrm{~cm}$; and $121-758 \mathrm{~A}-69 \mathrm{R}-1,37-43 \mathrm{~cm}$. Individual core portions were crushed using the shipboard agate grinder, mized, and aliquots of powder were distributed among shipboard scientists for shore-based analysis. Each set of powders was prepared using the same techniques, thus minimizing interlaboratory bias due to sample preparation.

\section{Laboratories and Summaries of Techniques}

Five laboratories provided data: shipboard (S: XRF), Amherst (A: XRF), MIT (M: NAA), Leicester (L: XRF and L: ICP), and Durham (D: NAA). Details of the analytical techniques used, analytical precision, and analytical accuracy relative to international reference standards are given in Peirce, Weissel, et al. (1989), Frey et al. (this volume), and this chapter. All Amherst and MIT data were determined in duplicate. Durham NAA and Leicester XRF data were determined on single samples; ICP determinations were made in duplicate.

The full interlaboratory data set is shown in Table 12. In this appendix, $\mathrm{Fe}_{2} \mathrm{O}_{3}(\mathrm{t})$ represents total iron as $\mathrm{Fe}_{2} \mathrm{O}_{3}$. All oxide data are reported on anhydrous basis, and trace elements on an as-received basis.

\section{Comparison of Data \\ Major and Minor Element Oxides}

The agreement between the replicate determinations of $\mathrm{TiO}_{2}, \mathrm{MnO}$, and $\mathrm{K}_{2} \mathrm{O}$ is excellent, with standard deviations of less than 0.05 (1s) Interlaboratory precision of other oxides decreases from $\mathrm{P}_{2} \mathrm{O}_{5}$ (s.d. 0.006 to 0.043 ), through $\mathrm{Fe}_{2} \mathrm{O}_{3}(\mathrm{t}), \mathrm{CaO}, \mathrm{Al}_{2} \mathrm{O}_{3}, \mathrm{Na}_{2} \mathrm{O}, \mathrm{MgO}$, to $\mathrm{SiO}_{2}$ (s.d. 0.15 to 0.36 ). In several cases the reproducibility is better than indicated by these values because one "aberrant" determination is responsible for increasing the standard deviation values (e.g., the low Leicester value for $\mathrm{Na}_{2} \mathrm{O}$ in Sample 121-756D-12R-2, 28-33 cm). Some systematic bias is evident; for example, the generally high values for $\mathrm{SiO}_{2}$ (but not in Sample 121-758A-69R-1, 37-43 cm) and $\mathrm{P}_{2} \mathrm{O}_{5}$ and low values for $\mathrm{K}_{2} \mathrm{O}$ reported by Leicester.

\section{Loss On Ignition}

Total loss on ignition in air of pre-dried samples was determined both on the ship and at Leicester; agreement between the measurements by the two laboratories is reasonable. Separate measurements of $\mathrm{CO}_{2}, \mathrm{H}_{2} \mathrm{O}^{+}$and $\mathrm{H}_{2} \mathrm{O}$ were made by the MIT group. It is noteworthy that the $\left(\mathrm{H}_{2} \mathrm{O}^{+}+\mathrm{CO}_{2}\right)$ loss determined by the MIT group is greater than the total ignition loss measured by the two other laboratories; this probably reflects compensating weight gain of iron oxidation accompanying atmospheric ignition.

\section{$\mathrm{XRF}$ and NAA Trace Elements $\mathrm{Nb}, \mathrm{Zr}, \mathrm{Y}, \mathrm{Sr}, \mathrm{Rb}, \mathrm{Ga}, \mathrm{Zn}, \mathrm{Cu}, \mathrm{Ni}$, $\mathrm{V}, \mathrm{Cr}$, and $\mathrm{Ba}$}

Agreement between the laboratories is, with some exceptions, good. Systematic biases do, however, occur: measurements of $\mathrm{Nb}$ and $\mathrm{Zn}$ made at Amherst are systematically higher than the other laboratories; meas-

\footnotetext{
${ }^{8}$ Department of Earth, Atmospheric and Planetary Sciences, Massachusetts Institute of Technology, Cambridge, MA 02139, U.S.A.

${ }^{9}$ Université Libre de Bruxelles, Belgium.
}

urements of $\mathrm{Y}$ and $\mathrm{Rb}$ made at Leicester are higher than the other laboratories (the difference between the measurements of $\mathrm{Rb}$ is particularly important at the low levels of Rb reported in many of the samples recovered from Holes $757 \mathrm{C}$ and $758 \mathrm{~A}$ ); and measurements of $\mathrm{Ni}$ made at Leicester are lower than at the other laboratories.

Considerable variation is seen in the duplicate determinations of Cr. NAA measurements of $\mathrm{Cr}$ made at MIT and Durham give excellent agreement. Furthermore, there is generally good agreement between these measurements and the XRF analyses made at Amherst for Samples 121-756D-6R-3, 0-8 cm, 121-756D-12R-2, 28-33 cm, 121-757C-9R-2, 0-10 cm, and 121-757C-12R-1, 104-110 cm (Leicester XRF determinations are systematically higher and shipboard measurements are variable). However, all of the XRF Cr measurements for Samples 121-758A-66R-4, 6-12 cm, and 121-758A-69R-1, 37-43 cm, are systematically much lower than the NAA measurements (which, again, are in good agreement with each other). We cannot account for these discrepancies.

\section{NAA Trace Elements Ta, Hf, Th, and Sc}

Agreement between the laboratories for $\mathrm{Ta}, \mathrm{Hf}$, and $\mathrm{Sc}$ is generally better than $10 \%$, but the thorium data show nonsystematic variations which are greater than the estimates of precision for the technique.

\section{Rare Earth Elements}

Rare earth elements have been determined by instrumental neutron activation analysis at MIT and Durham, and by inductively coupled plasma optical-emission spectrometry at Leicester. The data are plotted for comparative purposes in Figures 28 to 30 . In addition, $\mathrm{La}, \mathrm{Ce}$, and $\mathrm{Nd}$ were measured by XRF at Leicester and Ce was measured by XRF at Amherst. The XRF REE data have not been included in Figures 28 to 30 , or in the following discussion. Lan/Ybn and Lan/Cen represent chondrite-normalized $\mathrm{La} / \mathrm{Yb}$ and $\mathrm{La} / \mathrm{Ce}$ ratios, respectively.

\section{Sample 121-756D-6R-3, 0-8 cm}

La determinations show good agreement between the three laboratories but there is considerable variation in the abundances of the other elements (Fig. 28). In particular, values of $\mathrm{Ce}$ and Nd determined by NAA at Durham are higher than those measured at MIT or Leicester. A negative Eu anomaly is shown only by the Durham data ( $\mathrm{Eu} / \mathrm{Eu}^{*}=0.87$ (Durham), 1.06 (Leicester), and 1.07 (MIT)). The $\mathrm{La}_{\mathrm{n}} / \mathrm{Yb}_{\mathrm{n}}$ ratios of three patterns are not significantly different $(2.05,2.09$, and 2.13 , respectively). All patterns have a $\mathrm{La} / \mathrm{Ce}_{\mathrm{n}}$ ratio of less than 1 .

\section{Sample 121-756D-12R-2, 28-33 cm}

Durham again shows high Nd data. There is also discrepancy between the La values; for example, $\mathrm{La}_{n} / \mathrm{Ce}_{n}$ ratio varies from $>1$ (Durham) to $<1$ (MIT and Leicester). The Durham data show a significant negative Eu anomaly (Eu/Eu* $=0.83$ (Durham), 1.06 (Leicester), 1.03 (MIT)). $\mathrm{La} / \mathrm{Yb}_{\mathrm{n}}$ ratio varies from 2.44 (Durham), to 2.00 (Leicester) and 2.12 (MIT).

\section{Sample 121-757C-9R-2, 0-10 cm}

The high La determination made by Durham must be aberrant, as it was not corroborated by other NA, XRF, or ICP analysis (Fig. 29). Nonetheless, three other high La values were reported by Durham for basalts from the top of Hole $757 \mathrm{C}$. Although we have been unable to account for these discrepancies, they will not be pursued further here. All three determinations of this sample give small positive Eu anomalies $\left(\mathrm{Eu} / \mathrm{Eu}^{*}\right.$ for all three laboratories is 1.1$)$. $\mathrm{La} / \mathrm{Yb}_{\mathrm{n}}$ varies between 1.98 (Leicester) and 2.36 (MIT).

\section{Sample 121-757C-12R-1, 104-110 cm}

This sample was not analyzed by ICP. There is considerable discrepancy between the MIT and Durham patterns, especially in the Tb and $\mathrm{Yb}$ data. Both patterns show a negative Eu anomaly (Eu/Eu* $=0.68$ (Durham) and $0.86(\mathrm{MIT}))$.

\section{Samples 121-758A-66R-4, 6-12 cm, and 121-758A-69R-1,37-43 cm}

The high MIT La value for Sample 121-758A-66R-4, 6-12 cm is probably aberrant, but duplicate analyses yielded this high La value; possibly this aliquot has been contaminated with La. Again, the Durham data reveal small but significant Eu anomalies for both sets of data, whereas neither the MIT nor the Leicester data do (Fig. 30). The patterns 
Table 12. Whole-rock analyses of interlaboratory samples, Leg 121.

\begin{tabular}{|c|c|c|c|c|c|c|c|c|}
\hline & $\begin{array}{l}\text { Laboratory } \\
\text { and } \\
\text { technique }^{\mathrm{a}}\end{array}$ & $\begin{array}{l}\text { Hole } \\
\text { Core, section } \\
\text { Interval }(\mathrm{cm})\end{array}$ & $\begin{array}{c}756 \mathrm{D} \\
6 \mathrm{R}-3 \\
0-8\end{array}$ & $\begin{array}{l}756 \mathrm{D} \\
12 \mathrm{R}-2 \\
28-33\end{array}$ & $\begin{array}{l}757 \mathrm{C} \\
9 \mathrm{R}-2 \\
0-10\end{array}$ & $\begin{array}{c}757 \mathrm{C} \\
12 \mathrm{R}-1 \\
104-110\end{array}$ & $\begin{array}{c}758 \mathrm{~A} \\
66 \mathrm{R}-4 \\
6-12\end{array}$ & $\begin{array}{l}758 \mathrm{~A} \\
69 \mathrm{R}-1 \\
37-43\end{array}$ \\
\hline $\begin{array}{l}\mathrm{SiO}_{2} \\
\mathrm{SiO}_{2} \\
\mathrm{SiO}_{2} \\
\text { s.d. }\end{array}$ & $\begin{array}{l}\text { S: XRF } \\
\text { L: XRF } \\
\text { A: XRF }\end{array}$ & & $\begin{array}{c}48.58 \\
49.20 \\
48.59 \\
0.355\end{array}$ & $\begin{array}{c}48.94 \\
49.61 \\
49.35 \\
0.338\end{array}$ & $\begin{array}{c}48.32 \\
48.91 \\
48.45 \\
0.310\end{array}$ & $\begin{array}{c}51.46 \\
52.00 \\
51.67 \\
0.272\end{array}$ & $\begin{array}{c}49.79 \\
50.28 \\
50.04 \\
0.245\end{array}$ & $\begin{array}{c}49.41 \\
49.64 \\
49.68 \\
0.146\end{array}$ \\
\hline $\begin{array}{l}\mathrm{TiO}_{2} \\
\mathrm{TiO}_{2} \\
\mathrm{TiO}_{2} \\
\text { s.d. }\end{array}$ & $\begin{array}{l}\text { S: XRF } \\
\text { L: XRF } \\
\text { A: XRF }\end{array}$ & & $\begin{array}{l}2.08 \\
2.12 \\
2.12 \\
0.023\end{array}$ & $\begin{array}{l}2.01 \\
2.06 \\
2.07 \\
0.032\end{array}$ & $\begin{array}{l}0.78 \\
0.76 \\
0.81 \\
0.025\end{array}$ & $\begin{array}{l}0.92 \\
0.93 \\
0.96 \\
0.021\end{array}$ & $\begin{array}{l}1.32 \\
1.37 \\
1.36 \\
0.026\end{array}$ & $\begin{array}{l}1.35 \\
1.36 \\
1.39 \\
0.021\end{array}$ \\
\hline $\begin{array}{l}\mathrm{Al}_{2} \mathrm{O}_{3} \\
\mathrm{Al}_{2} \mathrm{O}_{3} \\
\mathrm{Al}_{2} \mathrm{O}_{3} \\
\text { s.d. }\end{array}$ & $\begin{array}{l}\text { S: XRF } \\
\text { L: XRF } \\
\text { A: XRF }\end{array}$ & & $\begin{array}{c}15.48 \\
15.93 \\
15.61 \\
0.232\end{array}$ & $\begin{array}{c}14.66 \\
15.03 \\
14.87 \\
0.186\end{array}$ & $\begin{array}{l}22.18 \\
22.55 \\
22.03 \\
0.268\end{array}$ & $\begin{array}{c}18.68 \\
18.93 \\
18.71 \\
0.137\end{array}$ & $\begin{array}{c}14.95 \\
15.18 \\
15.00 \\
0.121\end{array}$ & $\begin{array}{c}15.25 \\
15.27 \\
15.18 \\
0.047\end{array}$ \\
\hline $\begin{array}{l}\mathrm{Fe}_{2} \mathrm{O}_{3} \\
\mathrm{Fe}_{2} \mathrm{O}_{3} \\
\mathrm{Fe}_{2} \mathrm{O}_{3} \\
\text { s.d. }\end{array}$ & $\begin{array}{l}\text { S: XRF } \\
\text { L: XRF } \\
\text { A: XRF }\end{array}$ & & $\begin{array}{c}12.36 \\
12.23 \\
11.98 \\
0.193\end{array}$ & $\begin{array}{c}12.19 \\
12.24 \\
12.02 \\
0.115\end{array}$ & $\begin{array}{l}7.08 \\
6.94 \\
6.85 \\
0.116\end{array}$ & $\begin{array}{l}7.64 \\
7.63 \\
7.50 \\
0.078\end{array}$ & $\begin{array}{c}11.52 \\
11.44 \\
11.30 \\
0.111\end{array}$ & $\begin{array}{c}11.36 \\
11.31 \\
11.26 \\
0.050\end{array}$ \\
\hline $\begin{array}{l}\mathrm{MnO} \\
\mathrm{MnO} \\
\mathrm{MnO} \\
\text { s.d. }\end{array}$ & $\begin{array}{l}\text { S: XRF } \\
\text { L: XRF } \\
\text { A: XRF }\end{array}$ & & $\begin{array}{l}0.18 \\
0.17 \\
0.18 \\
0.006\end{array}$ & $\begin{array}{l}0.15 \\
0.15 \\
0.15 \\
0.000\end{array}$ & $\begin{array}{l}0.08 \\
0.08 \\
0.09 \\
0.003\end{array}$ & $\begin{array}{l}0.16 \\
0.17 \\
0.17 \\
0.006\end{array}$ & $\begin{array}{l}0.21 \\
0.19 \\
0.21 \\
0.012\end{array}$ & $\begin{array}{l}0.19 \\
0.17 \\
0.18 \\
0.010\end{array}$ \\
\hline $\begin{array}{l}\mathrm{MgO} \\
\mathrm{MgO} \\
\mathrm{MgO} \\
\text { s.d. }\end{array}$ & $\begin{array}{l}\text { S: XRF } \\
\text { L: XRF } \\
\text { A: XRF }\end{array}$ & & $\begin{array}{l}7.24 \\
7.28 \\
7.05 \\
0.123\end{array}$ & $\begin{array}{l}7.58 \\
7.53 \\
7.28 \\
0.161\end{array}$ & $\begin{array}{l}5.42 \\
5.97 \\
5.71 \\
0.275\end{array}$ & $\begin{array}{l}4.86 \\
5.44 \\
5.26 \\
0.297\end{array}$ & $\begin{array}{l}9.73 \\
9.62 \\
9.45 \\
0.141\end{array}$ & $\begin{array}{l}8.41 \\
8.49 \\
8.38 \\
0.057\end{array}$ \\
\hline $\begin{array}{l}\mathrm{CaO} \\
\mathrm{CaO} \\
\mathrm{CaO} \\
\text { s.d. }\end{array}$ & $\begin{array}{l}\text { S: XRF } \\
\text { L: XRF } \\
\text { A: XRF }\end{array}$ & & $\begin{array}{c}10.94 \\
11.14 \\
10.98 \\
0.106\end{array}$ & $\begin{array}{l}10.67 \\
10.90 \\
10.76 \\
0.116\end{array}$ & $\begin{array}{c}13.81 \\
13.77 \\
13.68 \\
0.067\end{array}$ & $\begin{array}{l}12.07 \\
12.20 \\
12.00 \\
0.101\end{array}$ & $\begin{array}{c}10.46 \\
10.42 \\
10.48 \\
0.031\end{array}$ & $\begin{array}{c}11.62 \\
11.61 \\
11.76 \\
0.084\end{array}$ \\
\hline $\begin{array}{l}\mathrm{Na}_{2} \mathrm{O} \\
\mathrm{Na}_{2} \mathrm{O} \\
\mathrm{Na}_{2} \mathrm{O} \\
\mathrm{Na}_{2} \mathrm{O} \\
\text { s.d. }\end{array}$ & $\begin{array}{l}\text { S: XRF } \\
\text { L: XRF } \\
\text { M: NAA } \\
\text { A: XRF }\end{array}$ & & $\begin{array}{l}2.56 \\
2.56 \\
2.53 \\
2.75 \\
0.119\end{array}$ & $\begin{array}{l}2.73 \\
2.17 \\
2.62 \\
2.84 \\
0.342\end{array}$ & $\begin{array}{l}1.90 \\
1.93 \\
1.86 \\
2.00 \\
0.070\end{array}$ & $\begin{array}{l}2.58 \\
2.58 \\
2.44 \\
2.67 \\
0.116\end{array}$ & $\begin{array}{l}2.01 \\
2.14 \\
2.15 \\
2.37 \\
0.130\end{array}$ & $\begin{array}{l}1.84 \\
2.08 \\
2.00 \\
2.28 \\
0.144\end{array}$ \\
\hline $\begin{array}{l}\mathrm{K}_{2} \mathrm{O} \\
\mathrm{K}_{2} \mathrm{O} \\
\mathrm{K}_{2} \mathrm{O} \\
\text { s.d. }\end{array}$ & $\begin{array}{l}\text { S: XRF } \\
\text { L: XRF } \\
\text { A: XRF }\end{array}$ & & $\begin{array}{l}0.30 \\
0.299 \\
0.315 \\
0.009\end{array}$ & $\begin{array}{l}0.55 \\
0.527 \\
0.556 \\
0.015\end{array}$ & $\begin{array}{l}0.15 \\
0.126 \\
0.150 \\
0.014\end{array}$ & $\begin{array}{l}0.76 \\
0.703 \\
0.759 \\
0.033\end{array}$ & $\begin{array}{l}0.11 \\
0.105 \\
0.126 \\
0.011\end{array}$ & $\begin{array}{l}0.09 \\
0.074 \\
0.092 \\
0.010\end{array}$ \\
\hline $\begin{array}{l}\mathrm{P}_{2} \mathrm{O}_{5} \\
\mathrm{P}_{2} \mathrm{O}_{5} \\
\mathrm{P}_{2} \mathrm{O}_{5} \\
\text { s.d. }\end{array}$ & $\begin{array}{l}\text { S: XRF } \\
\text { L: XRF } \\
\text { A: XRF }\end{array}$ & & $\begin{array}{l}0.17 \\
0.187 \\
0.176 \\
0.009\end{array}$ & $\begin{array}{l}0.16 \\
0.240 \\
0.171 \\
0.043\end{array}$ & $\begin{array}{l}0.06 \\
0.072 \\
0.065 \\
0.006\end{array}$ & $\begin{array}{l}0.07 \\
0.089 \\
0.076 \\
0.010\end{array}$ & $\begin{array}{l}0.08 \\
0.106 \\
0.095 \\
0.013\end{array}$ & $\begin{array}{l}0.09 \\
0.110 \\
0.101 \\
0.010\end{array}$ \\
\hline $\begin{array}{l}\text { LOI } \\
\text { LOI }\end{array}$ & $\begin{array}{l}\mathrm{S} \\
\mathrm{L}\end{array}$ & & $\begin{array}{l}0.82 \\
0.91\end{array}$ & $\begin{array}{l}1.20 \\
1.19\end{array}$ & $\begin{array}{l}1.36 \\
0.98\end{array}$ & $\begin{array}{l}1.19 \\
1.43\end{array}$ & $\begin{array}{l}1.20 \\
1.95\end{array}$ & $\begin{array}{l}0.91 \\
1.31\end{array}$ \\
\hline $\begin{array}{l}\mathrm{H}_{2} \mathrm{O}+ \\
\mathrm{H}_{2}-\end{array}$ & $\begin{array}{l}\mathrm{M} \\
\mathrm{M}\end{array}$ & & $\begin{array}{l}1.02 \\
0.75\end{array}$ & $\begin{array}{l}1.41 \\
0.93\end{array}$ & $\begin{array}{l}1.01 \\
0.91\end{array}$ & $\begin{array}{l}1.36 \\
0.70\end{array}$ & $\begin{array}{l}1.45 \\
1.75\end{array}$ & $\begin{array}{l}1.43 \\
1.59\end{array}$ \\
\hline $\mathrm{CO}_{2}$ & M & & 0.41 & 0.18 & 0.36 & 0.28 & 0.38 & 0.21 \\
\hline $\begin{array}{l}\mathrm{Nb} \\
\mathrm{Nb} \\
\mathrm{Nb} \\
\text { s.d. }\end{array}$ & $\begin{array}{l}\text { S: XRF } \\
\text { L: XRF } \\
\text { A: XRF }\end{array}$ & & $\begin{array}{l}9.0 \\
8.9 \\
9.3 \\
0.208\end{array}$ & $\begin{array}{l}8.0 \\
8.1 \\
8.8 \\
0.436\end{array}$ & $\begin{array}{l}2.4 \\
3.3 \\
3.5 \\
0.586\end{array}$ & $\begin{array}{c}9.1 \\
9.5 \\
10.4 \\
0.666\end{array}$ & $\begin{array}{l}3.6 \\
3.8 \\
4.1 \\
0.252\end{array}$ & $\begin{array}{l}3.8 \\
4.3 \\
4.9 \\
0.551\end{array}$ \\
\hline $\begin{array}{l}\mathrm{Zr} \\
\mathrm{Zr} \\
\mathrm{Zr} \\
\text { s.d. }\end{array}$ & $\begin{array}{l}\text { S: XRF } \\
\text { L: XRF } \\
\text { A: XRF }\end{array}$ & & $\begin{array}{l}119 \\
119.9 \\
124.0 \\
2.665\end{array}$ & $\begin{array}{l}114 \\
117.2 \\
117.7 \\
2.007\end{array}$ & $\begin{array}{l}50 \\
41.4 \\
48.6 \\
4.614\end{array}$ & $\begin{array}{l}156 \\
158.7 \\
162.0 \\
3.005\end{array}$ & $\begin{array}{l}69 \\
65.9 \\
69.0 \\
1.790\end{array}$ & $\begin{array}{l}74 \\
73.3 \\
73.4 \\
0.379\end{array}$ \\
\hline $\begin{array}{l}\mathrm{Y} \\
\mathrm{Y} \\
\mathrm{Y} \\
\text { s.d. }\end{array}$ & $\begin{array}{l}\text { S: XRF } \\
\text { L: XRF } \\
\text { A: XRF }\end{array}$ & & $\begin{array}{l}29 \\
29.8 \\
27.8 \\
1.007\end{array}$ & $\begin{array}{l}26 \\
28.6 \\
24.8 \\
1.943\end{array}$ & $\begin{array}{l}12 \\
14.0 \\
11.8 \\
1.217\end{array}$ & $\begin{array}{l}30 \\
32.2 \\
28.6 \\
1.815\end{array}$ & $\begin{array}{l}22 \\
21.6 \\
20.2 \\
0.945\end{array}$ & $\begin{array}{l}25 \\
26.8 \\
23.5 \\
1.652\end{array}$ \\
\hline $\begin{array}{l}\text { Sr } \\
\text { Sr } \\
\text { Sr } \\
\text { s.d. }\end{array}$ & $\begin{array}{l}\text { S: XRF } \\
\text { L: XRF } \\
\text { A: XRF }\end{array}$ & & $\begin{array}{l}177 \\
176.1 \\
175.9 \\
0.586\end{array}$ & $\begin{array}{l}170 \\
167.7 \\
168.6 \\
1.159\end{array}$ & $\begin{array}{l}179 \\
180.6 \\
181.6 \\
1.311\end{array}$ & $\begin{array}{l}166 \\
165.8 \\
168 \\
1.217\end{array}$ & $\begin{array}{l}135 \\
132.8 \\
136.3 \\
1.769\end{array}$ & $\begin{array}{l}135 \\
138.1 \\
134.6 \\
1.916\end{array}$ \\
\hline $\begin{array}{l}R b \\
R b \\
R b \\
\text { s.d. }\end{array}$ & $\begin{array}{l}\text { S: XRF } \\
\text { L: XRF } \\
\text { A: XRF }\end{array}$ & & $\begin{array}{l}1 \\
3.2 \\
1.2 \\
1.217\end{array}$ & $\begin{array}{l}42 \\
43.6 \\
40.6 \\
1.501\end{array}$ & $\begin{array}{l}1 \\
3.1 \\
1.6 \\
1.082\end{array}$ & $\begin{array}{l}8 \\
9.6 \\
7.1 \\
1.266\end{array}$ & $\begin{array}{l}1 \\
3.1 \\
0.99 \\
1.215\end{array}$ & $\begin{array}{l}0 \\
4.6 \\
0.74 \\
2.470\end{array}$ \\
\hline $\begin{array}{l}\mathrm{Ga} \\
\mathrm{Ga}\end{array}$ & $\begin{array}{l}\text { L: XRF } \\
\text { A: XRF }\end{array}$ & & $\begin{array}{l}20.1 \\
20.3\end{array}$ & $\begin{array}{l}22.4 \\
20.0\end{array}$ & $\begin{array}{l}19.1 \\
17.7\end{array}$ & $\begin{array}{l}20.4 \\
17.5\end{array}$ & $\begin{array}{l}18.6 \\
17.2\end{array}$ & $\begin{array}{l}18.7 \\
17.3\end{array}$ \\
\hline
\end{tabular}


Table 12 (continued).

\begin{tabular}{|c|c|c|c|c|c|c|c|c|}
\hline & $\begin{array}{l}\text { Laboratory } \\
\text { and } \\
\text { technique }^{\mathrm{a}}\end{array}$ & $\begin{array}{l}\text { Hole } \\
\text { Core, section } \\
\text { Interval }(\mathrm{cm})\end{array}$ & $\begin{array}{c}756 \mathrm{D} \\
6 \mathrm{R}-3 \\
0-8\end{array}$ & $\begin{array}{l}756 \mathrm{D} \\
12 \mathrm{R}-2 \\
28-33\end{array}$ & $\begin{array}{l}757 \mathrm{C} \\
9 \mathrm{R}-2 \\
0-10\end{array}$ & $\begin{array}{c}757 C \\
12 R-1 \\
104-110\end{array}$ & $\begin{array}{c}758 \mathrm{~A} \\
66 \mathrm{R}-4 \\
6-12\end{array}$ & $\begin{array}{l}758 \mathrm{~A} \\
69 \mathrm{R}-1 \\
37-43\end{array}$ \\
\hline s.d. & & & 0.141 & 1.697 & 0.990 & 2.051 & 0.990 & 0.990 \\
\hline $\begin{array}{l}\mathrm{Zn} \\
\mathrm{Zn} \\
\mathrm{Zn} \\
\text { s.d. }\end{array}$ & $\begin{array}{l}\text { S: XRF } \\
\text { L: XRF } \\
\text { A: XRF }\end{array}$ & & $\begin{array}{c}103 \\
99.6 \\
109.8 \\
5.194\end{array}$ & $\begin{array}{c}98 \\
95.1 \\
104.5 \\
4.814\end{array}$ & $\begin{array}{l}49 \\
48.4 \\
51.0 \\
1.361\end{array}$ & $\begin{array}{l}73 \\
66.7 \\
73.3 \\
3.727\end{array}$ & $\begin{array}{l}69 \\
66.6 \\
74.8 \\
4.216\end{array}$ & $\begin{array}{l}105 \\
102.2 \\
112.7 \\
5.437\end{array}$ \\
\hline $\mathrm{Cu}$ & S: XRF & & 101 & 70 & 52 & 64 & 124 & 134 \\
\hline $\begin{array}{l}\mathrm{Ni} \\
\mathrm{Ni} \\
\mathrm{Ni} \\
\text { s.d. }\end{array}$ & $\begin{array}{l}\text { S: XRF } \\
\text { L: XRF } \\
\text { A: XRF }\end{array}$ & & $\begin{array}{l}82 \\
67 \\
74.8 \\
7.502\end{array}$ & $\begin{array}{l}92 \\
76 \\
82.6 \\
8.041\end{array}$ & $\begin{array}{l}74 \\
68 \\
74.5 \\
3.617\end{array}$ & $\begin{array}{l}57 \\
43 \\
50.4 \\
7.004\end{array}$ & $\begin{array}{l}96 \\
88 \\
97.0 \\
4.933\end{array}$ & $\begin{array}{l}81 \\
72 \\
80.6 \\
5.085\end{array}$ \\
\hline $\begin{array}{l}\text { V } \\
\text { V } \\
\text { V } \\
\text { s.d. }\end{array}$ & $\begin{array}{l}\text { S: XRF } \\
\text { L: XRF } \\
\text { A: XRF }\end{array}$ & & $\begin{array}{l}343 \\
325.6 \\
317.0 \\
13.246\end{array}$ & $\begin{array}{l}313 \\
315.3 \\
291.9 \\
12.897\end{array}$ & $\begin{array}{l}172 \\
173.0 \\
168.7 \\
2.250\end{array}$ & $\begin{array}{l}218 \\
207.8 \\
195.4 \\
11.318\end{array}$ & $\begin{array}{l}340 \\
316.2 \\
303.9 \\
18.353\end{array}$ & $\begin{array}{l}324 \\
313.3 \\
294.2 \\
15.096\end{array}$ \\
\hline $\begin{array}{l}\mathrm{Cr} \\
\mathrm{Cr} \\
\mathrm{Cr} \\
\mathrm{Cr} \\
\mathrm{Cr} \\
\text { s.d. }\end{array}$ & $\begin{array}{l}\text { S: XRF } \\
\text { L: XRF } \\
\text { D: NAA } \\
\text { A: XRF } \\
\text { M: NAA }\end{array}$ & & $\begin{array}{l}253 \\
275.1 \\
256 \\
264.0 \\
254 \\
\quad 5.292\end{array}$ & $\begin{array}{l}184 \\
213.3 \\
203 \\
197.9 \\
200 \\
\quad 2.563\end{array}$ & $\begin{array}{l}157 \\
183.3 \\
174 \\
174.8 \\
172 \\
\quad 1.442\end{array}$ & $\begin{array}{c}86 \\
106.4 \\
92 \\
98.5 \\
96 \\
3.279\end{array}$ & $\begin{array}{l}230 \\
260.1 \\
319 \\
242.4 \\
332 \\
48.416\end{array}$ & $\begin{array}{l}160 \\
195.3 \\
257 \\
162.4 \\
256 \\
54.331\end{array}$ \\
\hline $\begin{array}{l}\mathrm{Ba} \\
\mathrm{Ba} \\
\mathrm{Ba} \\
\text { s.d. }\end{array}$ & $\begin{array}{l}\text { S: XRF } \\
\text { L: XRF } \\
\text { A: XRF }\end{array}$ & & $\begin{array}{l}47.0 \\
45.7 \\
49.4 \\
1.877\end{array}$ & $\begin{array}{l}47.0 \\
39.3 \\
47.9 \\
4.727\end{array}$ & $\begin{array}{l}20.2 \\
21.6 \\
21.3 \\
0.737\end{array}$ & $\begin{array}{l}71.5 \\
74.1 \\
80.8 \\
4.798\end{array}$ & $\begin{array}{l}24.6 \\
26.0 \\
11.8 \\
7.826\end{array}$ & $\begin{array}{l}22.6 \\
19.7 \\
24.5 \\
2.417\end{array}$ \\
\hline $\begin{array}{l}\mathrm{La} \\
\mathrm{La} \\
\mathrm{La} \\
\mathrm{La} \\
\text { s.d. }\end{array}$ & $\begin{array}{l}\text { L: XRF } \\
\text { L: ICP } \\
\text { D: NAA } \\
\text { M: NAA }\end{array}$ & & $\begin{array}{l}10.7 \\
8.3 \\
8.3 \\
7.92 \\
0.219\end{array}$ & $\begin{array}{l}7.6 \\
7.3 \\
9.0 \\
7.24 \\
0.999\end{array}$ & $\begin{array}{c}2.9 \\
3.64 \\
13.6 \\
4.1 \\
5.622\end{array}$ & $\begin{array}{c}12.4 \\
\text { n.d. } \\
14.3 \\
11.2 \\
2.192\end{array}$ & $\begin{array}{l}6.3 \\
3.2 \\
4.2 \\
7.32 \\
2.149\end{array}$ & $\begin{array}{l}\text { n.d. } \\
4.52 \\
4.0 \\
4.12 \\
0.272\end{array}$ \\
\hline $\begin{array}{l}\mathrm{Ce} \\
\mathrm{Ce} \\
\mathrm{Ce} \\
\mathrm{Ce} \\
\mathrm{Ce} \\
\text { s.d. }\end{array}$ & $\begin{array}{l}\text { L: XRF } \\
\text { L: ICP } \\
\text { D: NAA } \\
\text { A: XRF } \\
\text { M: NAA }\end{array}$ & & $\begin{array}{c}18.1 \\
22.0 \\
24.9 \\
22.8 \\
22.2 \\
1.418\end{array}$ & $\begin{array}{c}20.0 \\
20.3 \\
21.6 \\
23.5 \\
21.8 \\
1.044\end{array}$ & $\begin{array}{c}11.9 \\
9.1 \\
10.3 \\
13.7 \\
9.8 \\
2.122\end{array}$ & $\begin{array}{c}26.3 \\
\text { n.d. } \\
28.8 \\
28.0 \\
27.0 \\
0.902\end{array}$ & $\begin{array}{c}17.2 \\
10.9 \\
11.3 \\
18.8 \\
10.5 \\
4.579\end{array}$ & $\begin{array}{c}\text { n.d. } \\
11.1 \\
12.8 \\
16.2 \\
12.2 \\
2.157\end{array}$ \\
\hline $\begin{array}{l}\mathrm{Nd} \\
\mathrm{Nd} \\
\mathrm{Nd} \\
\mathrm{Nd} \\
\text { s.d. }\end{array}$ & $\begin{array}{l}\text { L: XRF } \\
\text { L: ICP } \\
\text { D: NAA } \\
\text { M: NAA }\end{array}$ & & $\begin{array}{l}13.5 \\
13.8 \\
15.2 \\
13.4 \\
0.945\end{array}$ & $\begin{array}{l}12.0 \\
12.7 \\
14.7 \\
12.8 \\
1.127\end{array}$ & $\begin{array}{l}4.9 \\
5.8 \\
5.4 \\
5.6 \\
0.195\end{array}$ & $\begin{array}{c}15.1 \\
\text { n.d. } \\
16.6 \\
14.0 \\
1.838\end{array}$ & $\begin{array}{l}9.6 \\
8.0 \\
7.8 \\
7.6 \\
0.155\end{array}$ & $\begin{array}{l}\text { n.d. } \\
8.1 \\
7.6 \\
7.8 \\
0.268\end{array}$ \\
\hline $\begin{array}{l}\text { Sm } \\
\text { Sm } \\
\text { Sm } \\
\text { s.d. }\end{array}$ & $\begin{array}{l}\text { L: ICP } \\
\text { D: NAA } \\
\text { M: NAA }\end{array}$ & & $\begin{array}{l}4.26 \\
4.22 \\
3.82 \\
0.243\end{array}$ & $\begin{array}{l}4.07 \\
4.21 \\
3.76 \\
0.230\end{array}$ & $\begin{array}{l}1.80 \\
1.63 \\
1.56 \\
0.123\end{array}$ & $\begin{array}{l}\text { n.d. } \\
4.00 \\
3.70 \\
0.212\end{array}$ & $\begin{array}{l}3.11 \\
2.47 \\
2.33 \\
0.416\end{array}$ & $\begin{array}{l}2.94 \\
2.55 \\
2.52 \\
0.234\end{array}$ \\
\hline $\begin{array}{l}\text { Eu } \\
\text { Eu } \\
\text { Eu } \\
\text { s.d. }\end{array}$ & $\begin{array}{l}\text { L: ICP } \\
\text { D: NAA } \\
\text { M: NAA }\end{array}$ & & $\begin{array}{l}1.66 \\
1.31 \\
1.44 \\
0.177\end{array}$ & $\begin{array}{l}1.57 \\
1.20 \\
1.38 \\
0.185\end{array}$ & $\begin{array}{l}0.72 \\
0.67 \\
0.64 \\
0.040\end{array}$ & $\begin{array}{l}\text { n.d. } \\
1.02 \\
1.12 \\
0.071\end{array}$ & $\begin{array}{l}0.97 \\
0.79 \\
0.93 \\
0.095\end{array}$ & $\begin{array}{l}1.06 \\
0.85 \\
0.94 \\
0.105\end{array}$ \\
\hline Gd & L: ICP & & 5.45 & 5.07 & 2.23 & n.d. & 3.43 & 3.69 \\
\hline $\begin{array}{l}\mathrm{Tb} \\
\mathrm{Tb} \\
\text { s.d. }\end{array}$ & $\begin{array}{l}\text { D: NAA } \\
\text { M: NAA }\end{array}$ & & $\begin{array}{l}0.82 \\
0.71 \\
0.078\end{array}$ & $\begin{array}{l}0.73 \\
0.72 \\
0.007\end{array}$ & $\begin{array}{l}0.37 \\
0.34 \\
0.021\end{array}$ & $\begin{array}{l}0.90 \\
0.70 \\
0.141\end{array}$ & $\begin{array}{l}0.62 \\
0.53 \\
0.064\end{array}$ & $\begin{array}{l}0.54 \\
0.55 \\
0.007\end{array}$ \\
\hline Dy & L: ICP & & 5.35 & 5.07 & 2.32 & n.d. & 3.86 & 4.18 \\
\hline $\mathrm{Er}$ & L: ICP & & 2.87 & 2.63 & 1.13 & n.d. & n.d. & 1.89 \\
\hline $\begin{array}{l}\mathrm{Yb} \\
\mathrm{Yb} \\
\mathrm{Yb} \\
\text { s.d. }\end{array}$ & $\begin{array}{l}\text { L: ICP } \\
\text { D: NAA } \\
\text { M: NAA }\end{array}$ & & $\begin{array}{l}2.66 \\
2.71 \\
2.49 \\
0.115\end{array}$ & $\begin{array}{l}2.44 \\
2.47 \\
2.28 \\
0.102\end{array}$ & $\begin{array}{l}1.23 \\
1.33 \\
1.16 \\
0.085\end{array}$ & $\begin{array}{l}\text { n.d. } \\
3.59 \\
2.84 \\
0.530\end{array}$ & $\begin{array}{l}2.04 \\
2.37 \\
2.12 \\
0.172\end{array}$ & $\begin{array}{l}2.40 \\
2.48 \\
2.27 \\
0.106\end{array}$ \\
\hline $\begin{array}{l}\text { Lu } \\
\text { Lu } \\
\text { Lu } \\
\text { s.d. }\end{array}$ & $\begin{array}{l}\text { L: ICP } \\
\text { D: NAA } \\
\text { M: NAA }\end{array}$ & & $\begin{array}{l}0.39 \\
0.39 \\
0.37 \\
0.012\end{array}$ & $\begin{array}{l}0.35 \\
0.39 \\
0.35 \\
0.023\end{array}$ & $\begin{array}{l}0.23 \\
0.18 \\
0.21 \\
0.025\end{array}$ & $\begin{array}{l}\text { n.d. } \\
0.50 \\
0.44 \\
0.042\end{array}$ & $\begin{array}{l}0.32 \\
0.33 \\
0.32 \\
0.006\end{array}$ & $\begin{array}{l}0.38 \\
0.40 \\
0.36 \\
0.020\end{array}$ \\
\hline $\begin{array}{l}\text { Ta } \\
\text { Ta } \\
\text { s.d. }\end{array}$ & $\begin{array}{l}\text { D: NAA } \\
\text { M: NAA }\end{array}$ & & $\begin{array}{l}0.64 \\
0.58 \\
0.347\end{array}$ & $\begin{array}{l}0.63 \\
0.60 \\
0.342\end{array}$ & $\begin{array}{l}0.20 \\
0.23 \\
0.111\end{array}$ & $\begin{array}{l}0.68 \\
0.54 \\
0.335\end{array}$ & $\begin{array}{l}0.28 \\
0.29 \\
0.161\end{array}$ & $\begin{array}{l}0.26 \\
0.30 \\
0.151\end{array}$ \\
\hline $\begin{array}{l}\text { Hf } \\
\text { Hf } \\
\text { s.d. }\end{array}$ & $\begin{array}{l}\text { D: NAA } \\
\text { M: NAA }\end{array}$ & & $\begin{array}{l}3.09 \\
2.81 \\
1.509\end{array}$ & $\begin{array}{l}2.92 \\
2.80 \\
1.455\end{array}$ & $\begin{array}{l}1.03 \\
1.07 \\
0.543\end{array}$ & $\begin{array}{l}3.63 \\
3.51 \\
1.869\end{array}$ & $\begin{array}{l}1.67 \\
1.72 \\
0.886\end{array}$ & $\begin{array}{l}1.88 \\
1.82 \\
0.981\end{array}$ \\
\hline
\end{tabular}


Table 12 (continued).

\begin{tabular}{|c|c|c|c|c|c|c|c|c|}
\hline & $\begin{array}{l}\text { Laboratory } \\
\text { and } \\
\text { technique }^{\mathrm{a}}\end{array}$ & $\begin{array}{l}\text { Hole } \\
\text { Core, section } \\
\text { Interval }(\mathrm{cm})\end{array}$ & $\begin{array}{c}756 \mathrm{D} \\
6 \mathrm{R}-3 \\
0-8\end{array}$ & $\begin{array}{l}756 \mathrm{D} \\
12 \mathrm{R}-2 \\
28-33\end{array}$ & $\begin{array}{l}757 C \\
9 \mathrm{R}-2 \\
0-10\end{array}$ & $\begin{array}{c}757 C \\
12 R-1 \\
104-110\end{array}$ & $\begin{array}{c}758 \mathrm{~A} \\
66 \mathrm{R}-4 \\
6-12\end{array}$ & $\begin{array}{l}758 \mathrm{~A} \\
69 \mathrm{R}-1 \\
37-43\end{array}$ \\
\hline Th & D: NAA & & 0.90 & 0.96 & 0.16 & 1.65 & 0.48 & 0.34 \\
\hline Th & M: NAA & & 0.70 & 0.62 & 0.29 & 1.63 & n.d. & 0.38 \\
\hline s.d. & & & 0.422 & 0.420 & 0.195 & 0.132 & 0.287 & 0.359 \\
\hline U & D: NAA & & 0.55 & 0.48 & n.d. & 0.36 & n.d. & n.d. \\
\hline W & D: NAA & & 5.5 & 6.2 & 2.2 & 5.3 & 2.7 & 3.5 \\
\hline $\mathrm{Sc}$ & D: NAA & & 43.2 & 44.1 & 26.1 & 29.5 & 48.9 & 46.0 \\
\hline $\mathrm{Sc}$ & M: NAA & & 40.4 & 43.4 & 25.9 & 28.4 & 47.6 & 44.6 \\
\hline s.d. & & & 1.980 & 0.495 & 0.141 & 0.778 & 0.919 & 0.990 \\
\hline Co & M: NAA & & 46.4 & 46.8 & 29.1 & 29.8 & 48.4 & 46.6 \\
\hline Cs & D: NAA & & n.d. & 1.13 & n.d. & n.d. & n.d. & n.d. \\
\hline Cs & M: NAA & & n.d. & 1.09 & n.d. & n.d. & n.d. & n.d. \\
\hline
\end{tabular}

Notes: s.d. = standard deviation; n.d. = not determined. Oxide data determined on fused glass beads and given on an anhydrous basis; trace elements measured on unignited powder samples.

a Laboratories: $\mathrm{S}=$ shipboard, $\mathrm{L}=$ Leicester, $\mathrm{A}=$ Amherst, and $\mathrm{M}=$ Massachusetts Institute of Technology. Techniques: XRF $=$ X-ray fluorescence, $\mathrm{NAA}=$ neutron activation analysis, $\mathrm{ICP}=$ inductively coupled plasma spectrometry.

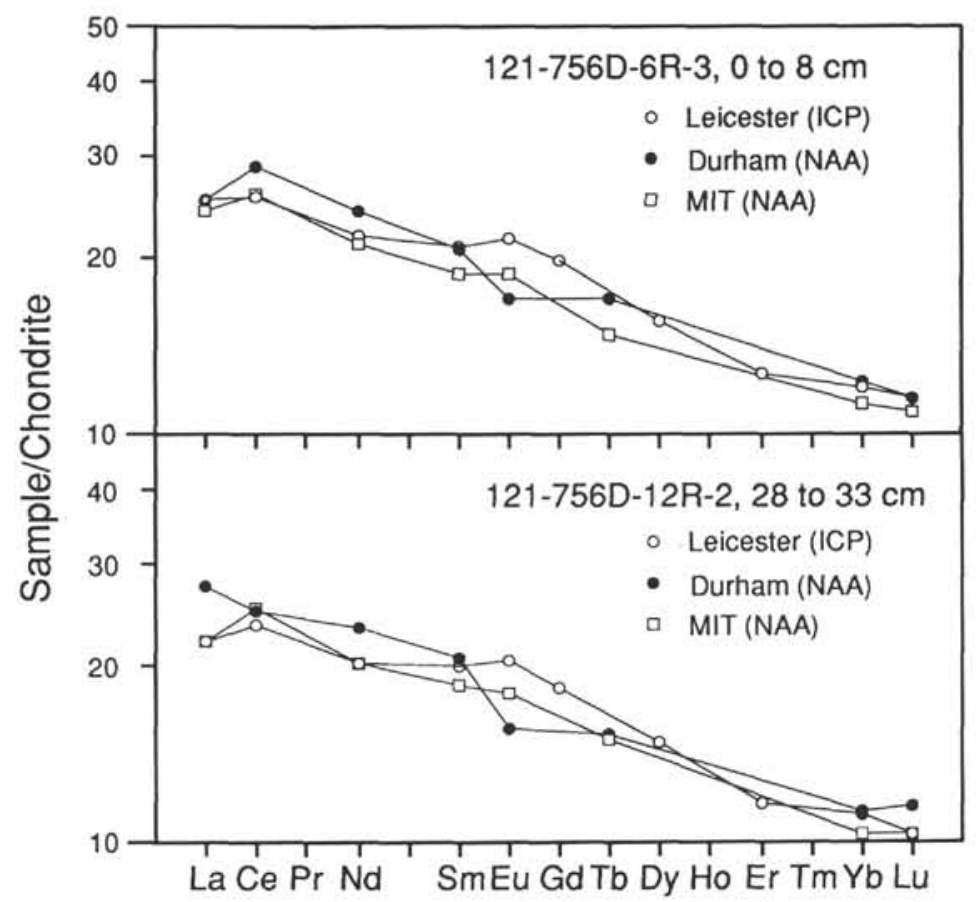

Figure 28. Chondrite-normalized rare earth element patterns for Samples 121-756D$6 \mathrm{R}-3,0-8 \mathrm{~cm}$, and $121-756 \mathrm{D}-12 \mathrm{R}-2,28-33 \mathrm{~cm}$. Normalizing values from Nakamura (1974) are given in Figure 29.

of Sample 121-758A-69R-1, 37-43 cm, determined by NAA have low $\mathrm{Lan} / \mathrm{Ce}_{\mathrm{n}}$ ratios, whereas the ICP-determined pattern does not.

\section{Conclusions}

1. The replicate analysis of six basalts illustrates the need for careful interlaboratory monitoring. The agreement between major and minor oxides and most XRF trace elements (with the exception of $\mathrm{Ni}, \mathrm{Cr}$, and, to a lesser extent, V) is generally good.

2. The agreement between NAA- and ICP-determined rare earth elements is less satisfactory. This is a particularly important considera- tion if detailed petrogenetic modeling is to be undertaken in the future. The discrepancies in REE determinations between the three laboratories is greater than that expected by instrumental precision estimates.

3. Subsequent merging of the NAA and ICP data sets determined at MIT, Durham, and Leicester will only be possible after exhaustive interlaboratory monitoring, but merging of the XRF data sets may be possible if corrections are applied using the data in Table 12.

4. Most encouraging is the quality of data produced during Leg 121 by the shipboard XRF analyses, which is as good as shore-based counterparts for many elements. 


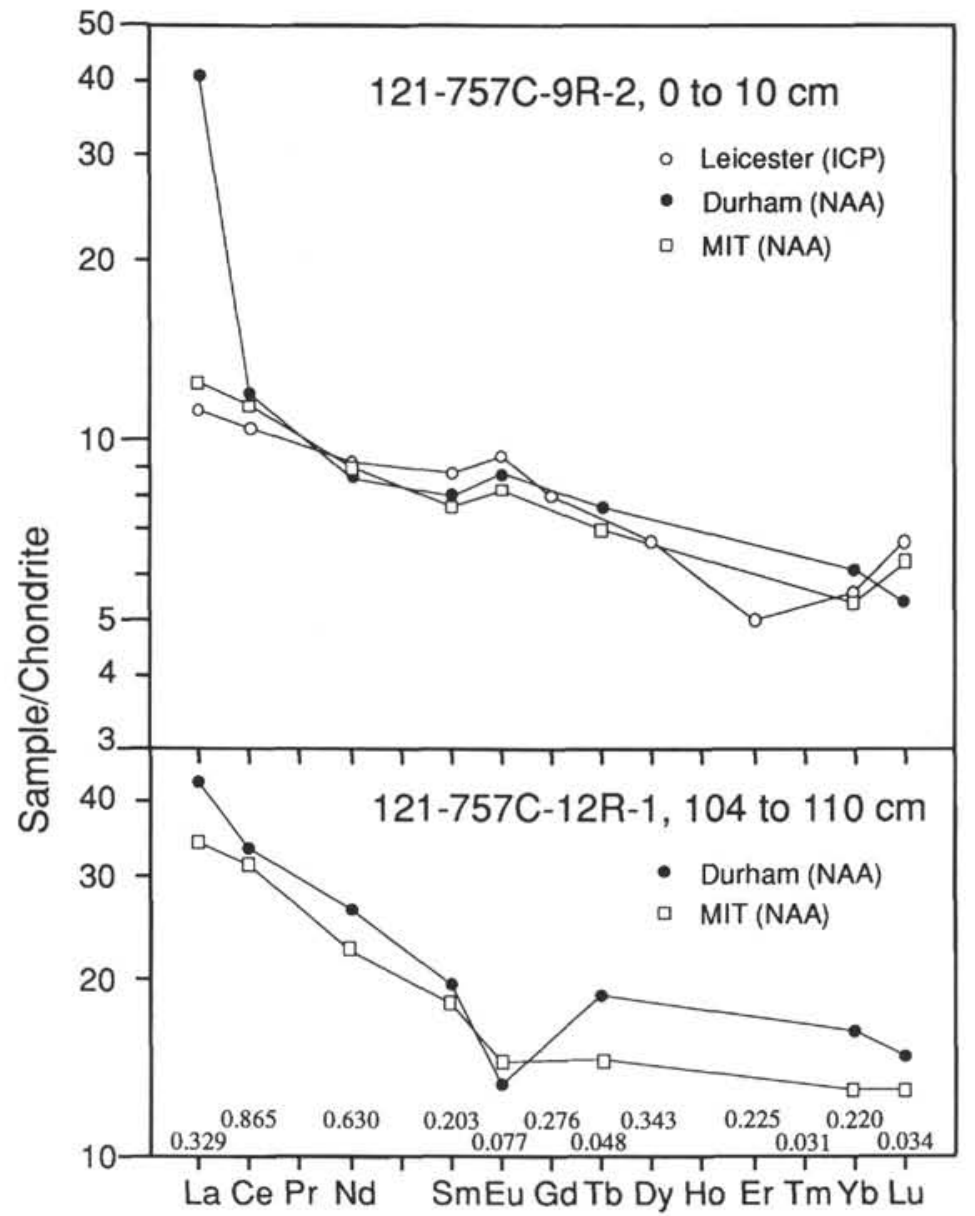

Figure 29. Chondrite-normalized rare earth element patterns for Samples 121-757C9R-2, 0-10 cm, and 121-757C-12R-1, 104-110. Normalizing values from Nakamura (1974). 


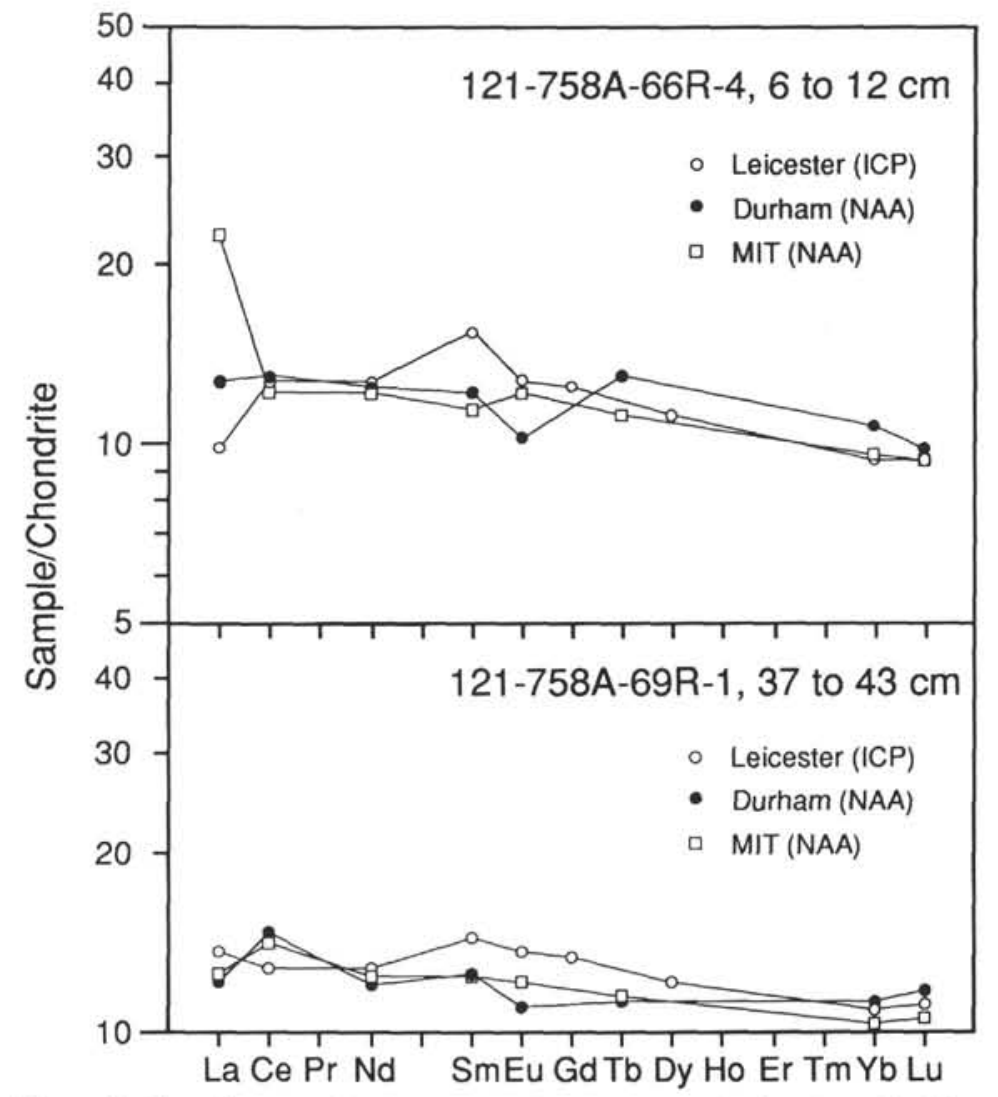

Figure 30. Chondrite-normalized rare earth element patterns for Samples 121-758A$66 \mathrm{R}-4,6-12 \mathrm{~cm}$, and $121-758 \mathrm{~A}-69 \mathrm{R}-1,37-43 \mathrm{~cm}$. Normalizing values from Nakamura (1974) are given in Figure 29. 